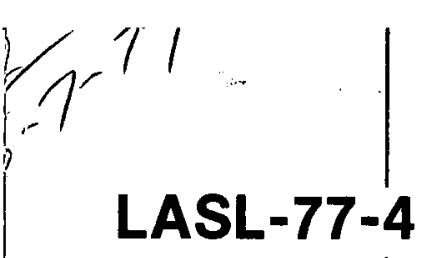

Issued: May 1977

\title{
Pajarito Plateau
}

\section{Archaeological Survey and Excavations}

by

\author{
Charlie R. Steen
}




\section{DISCLAIMER}

This report was prepared as an account of work sponsored by an agency of the United States Government. Neither the United States Government nor any agency Thereof, nor any of their employees, makes any warranty, express or implied, or assumes any legal liability or responsibility for the accuracy, completeness, or usefulness of any information, apparatus, product, or process disclosed, or represents that its use would not infringe privately owned rights. Reference herein to any specific commercial product, process, or service by trade name, trademark, manufacturer, or otherwise does not necessarily constitute or imply its endorsement, recommendation, or favoring by the United States Government or any agency thereof. The views and opinions of authors expressed herein do not necessarily state or reflect those of the United States Government or any agency thereof. 


\section{DISCLAIMER}

Portions of this document may be illegible in electronic image products. Images are produced from the best available original document. 

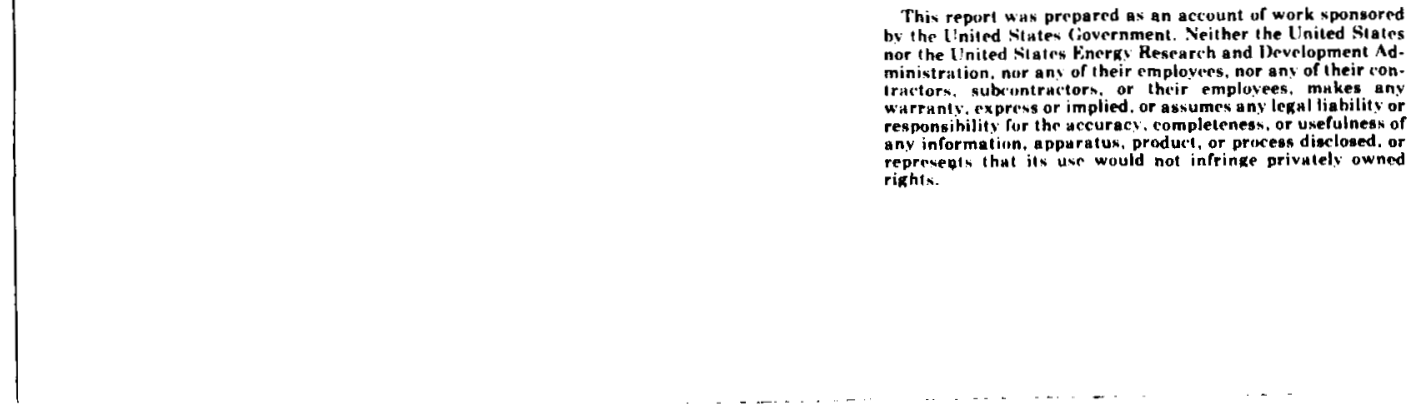
any information, apparatus, produet, or prescess diculnesn of represepts.
righis. 


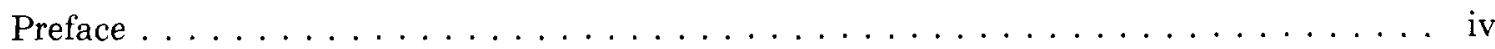

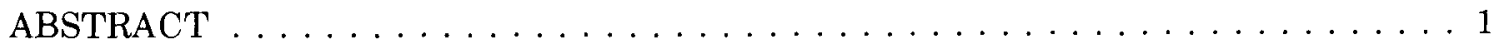

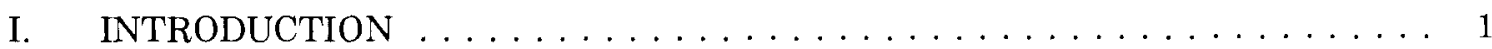

II. ARCHAEOLOGICAL INVESTIGATIONS FROM 1880 THROUGH WORLD WAR II 3

Post World War $\Pi$ Work $\ldots \ldots \ldots \ldots \ldots \ldots \ldots$

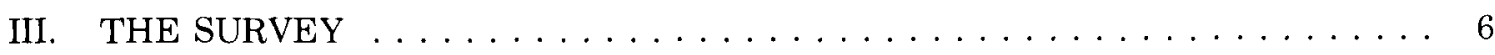

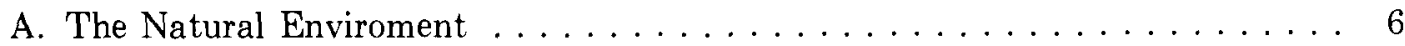

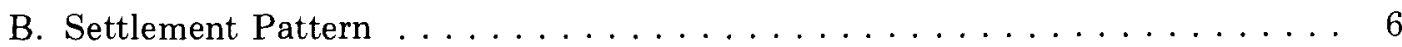

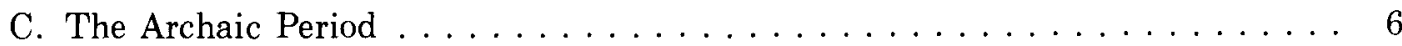

D. Pueblo Indians on the Pajarito Plateau $\ldots \ldots \ldots \ldots \ldots \ldots \ldots \ldots$

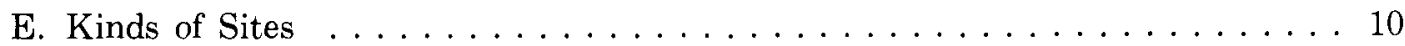

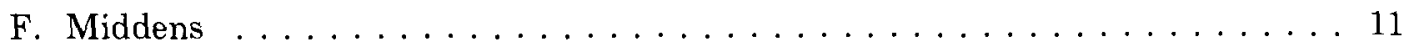

G. Expansion of the Small Sites $\ldots \ldots \ldots \ldots \ldots \ldots \ldots \ldots \ldots \ldots \ldots$

H. Plaza Sites . . . . . . . . . . . . . . . . . . . . . . . . 13

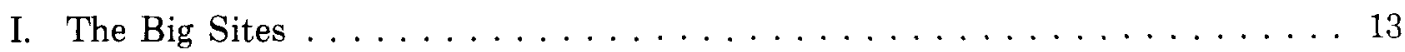

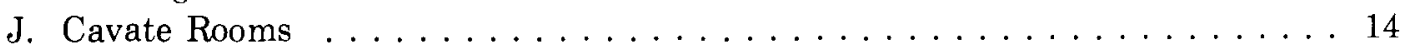

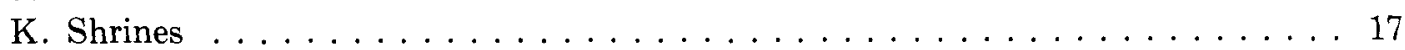

1. Rough Circles ......................... 17

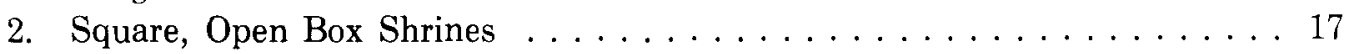

3. Rock Art Shrines . . . . . . . . . . . . . . . . . . . 20

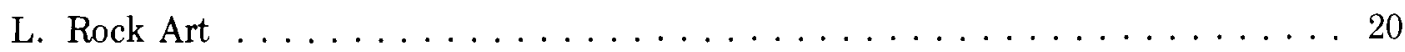

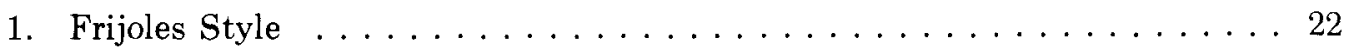

2. Mortandad Style . . . . . . . . . . . . . . . . . 22

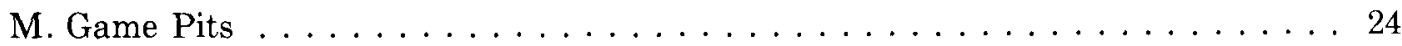

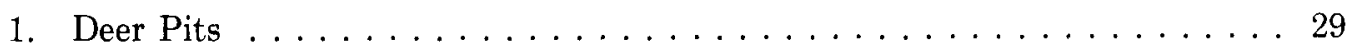

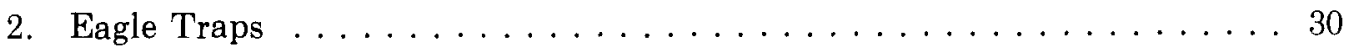

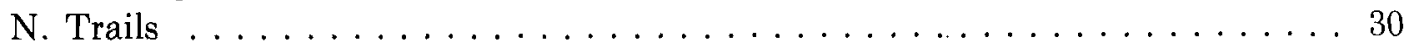

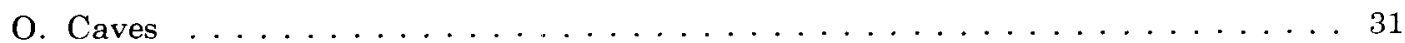

P. Water-Collecting Device . . . . . . . . . . . . . . . . 31

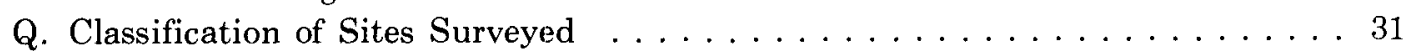

IV. AGRICULTURE ON THE PAJARITO PLATEAU $\ldots \ldots \ldots \ldots \ldots \ldots \ldots$

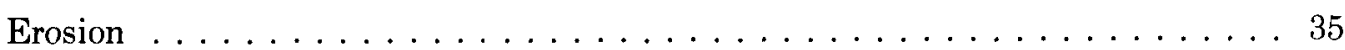

V. SOME IMPORTANT AND INTERESTING RUINS $\ldots \ldots \ldots \ldots \ldots \ldots$

VI. SOME THOUGHTS ON PAJARITAN ARCHAEOLOGY . . . . . . . . 39

VII. ACKNOWLEDGMENTS $\ldots \ldots \ldots \ldots \ldots \ldots \ldots \ldots \ldots \ldots \ldots \ldots$

APPENDIX. SITES EXCAVATED ON THE PAJARITO PLATEAU, 1950-1974 . . . . 43

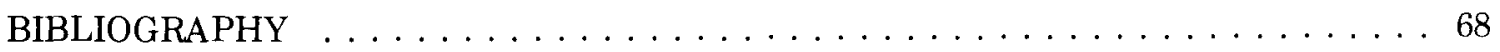

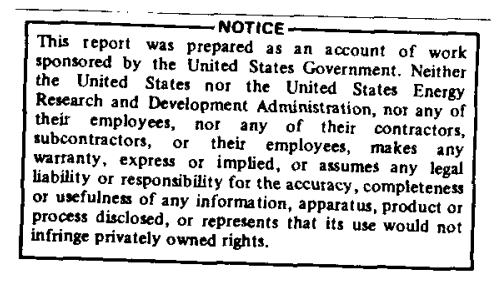




\section{PREFACE}

by

Wayne C. Hanson

This report presents the results of a three-year survey of archaeological sites in the Los Alamos Scientific Laboratory (LASL) environs, conducted by Charlie R. Steen, former Chief Archaeologist of the Southwest Region for the National Park Service and now a LASL consultant on archaeological matters. The survey, made between March 1973 and July 1975, had three main objectives.

- To evaluate and summarize the archaeological salvage operations that Frederick C. V. Worman conducted on LASL lands before his death in 1971.

- To survey LASL environs for archaeological sites in addition to those that Worman excavated or noted and to summarize the findings in a report that would be an effective instrument in construction planning, to avoid damage to such sites and to provide the lead-time necessary to salvage sites jeoparized by LASL operations deemed to have greater priority in the National interest.

- To recommend certain unique sites for registration with the Federal Government to ensure their preservation for future generations by establishing the formal procedures through which responsibility for and authority to protect the sites are clearly outlined.
All artifacts recovered by salvage archaeology on LASL lands must, by law, be placed in suitable public museums. Accordingly, the several boxes of material recovered by Worman and, more recently, by Steen have been given to the State of New Mexico Museum Laboratory of Anthropology, the National Park Service Bandelier National Monument, and the Los Alamos County Historical Society. A few representative artifacts, most contributed by Laboratory personnel who found them during their tenure at LASL, are mounted temporarily in small displays at the Meson Facility and the Occupational Health Laboratory. At some suitable time, they will be deposited in one of the above collections.

Archaeology is but one of the several disciplines being used in a comprehensive inventory of natural resources by LASL's Environmental Studies Group, $\mathrm{H}-8$, to describe the environmental background against which LASL operations are conducted. As we better understand the past, we are better enabled to plan for the future, and Charlie Steen, in his own inimitable style, has enriched LASL's contribution to the future by providing us this treatise on early man on the Pajarito Plateau. 


\title{
PAJARITO PLATEAU ARCHAEOLOGICAL SURVEY AND EXCAVATIONS
}

by

\author{
Charlie R. Steen
}

\begin{abstract}
Los Alamos Scientific Laboratory lands were surveyed to locate preColumbian Indian ruins. The survey results will permit future construction to be planned so that most of the ancient sites in the area can be preserved.

Indian occupation of the area occurred principally from late Pueblo III times (late 13th century) until early Pueblo V (about the middle of the 16th century). There are evidences of sporadic Indian use of the area for some 10000 years - one Folsom point has been found, as well as many other archaic varieties of projectile points. Continued use of the region well into the historic period is indicated by pictographic art that portrays horses.

In addition to an account of the survey, the report contains summaries of excavations made on Laboratory lands between 1950 and 1975.
\end{abstract}

\section{Introduction}

This report delineates an archaeological survey and excavations of ruins within and near the boundaries of the Los Alamos Scientific Laboratory (LASL) of the University of California. The Laboratory is located on part of the Pajarito Plateau, in north-central New Mexico.

"Pajarito Plateau" is the name now commonly given to the high mesas that slope eastward from the Jemez Mountains to the Rio Grande. From north to south, the plateau extends from Puye on the Santa Clara Reservation to Cañada de Cochiti, a distance of about $35 \mathrm{~km}$ (ca 22 miles). The plateau width varies from 6 to $16 \mathrm{~km}$ (4-10 miles). The mesa elevations are about $2300 \mathrm{~m}(7500 \mathrm{ft})$ at the foot of the mountains, dropping to some $1850 \mathrm{~m}(6000 \mathrm{ft})$ at their eastern edges near the river (Fig. 1).

The name "Pajarito" apparently was in common use by the late 19th century. It was first used in archaeological literature in 1904 by Edgar Lee
Hewett, a pioneer southwestern archaeologist, in describing a survey of the area from Puye to Frijoles Canyon which he had made in 1896 . The name had its derivation in the Tewa name for a large ruin (and the adjacent canyon), which we have shortened to "Tshirege," meaning Bird House or House of the Bird People, and which Spanish-speaking settlers translated as Pajarito (Harrington 1916, p. 281). Hewett also used the term Pajaritan to refer to the pre-Columbian inhabitants of the plateau, and that word is used in this report.

Hewett's terminology was inconsistent; he titled a 1906 paper, "Antiquities of the Jemez Plateau." Douglas (1917) also refers to the Jemez Plateau. Douglas was geologist and surveyor for the General Land Office, the Federal agency that had juriscliction over the Public Domain, of which the Pajarito Plateau was then a part. Now, geographers and writers in all fields seem to have settled on use of the name "Pajarito." 


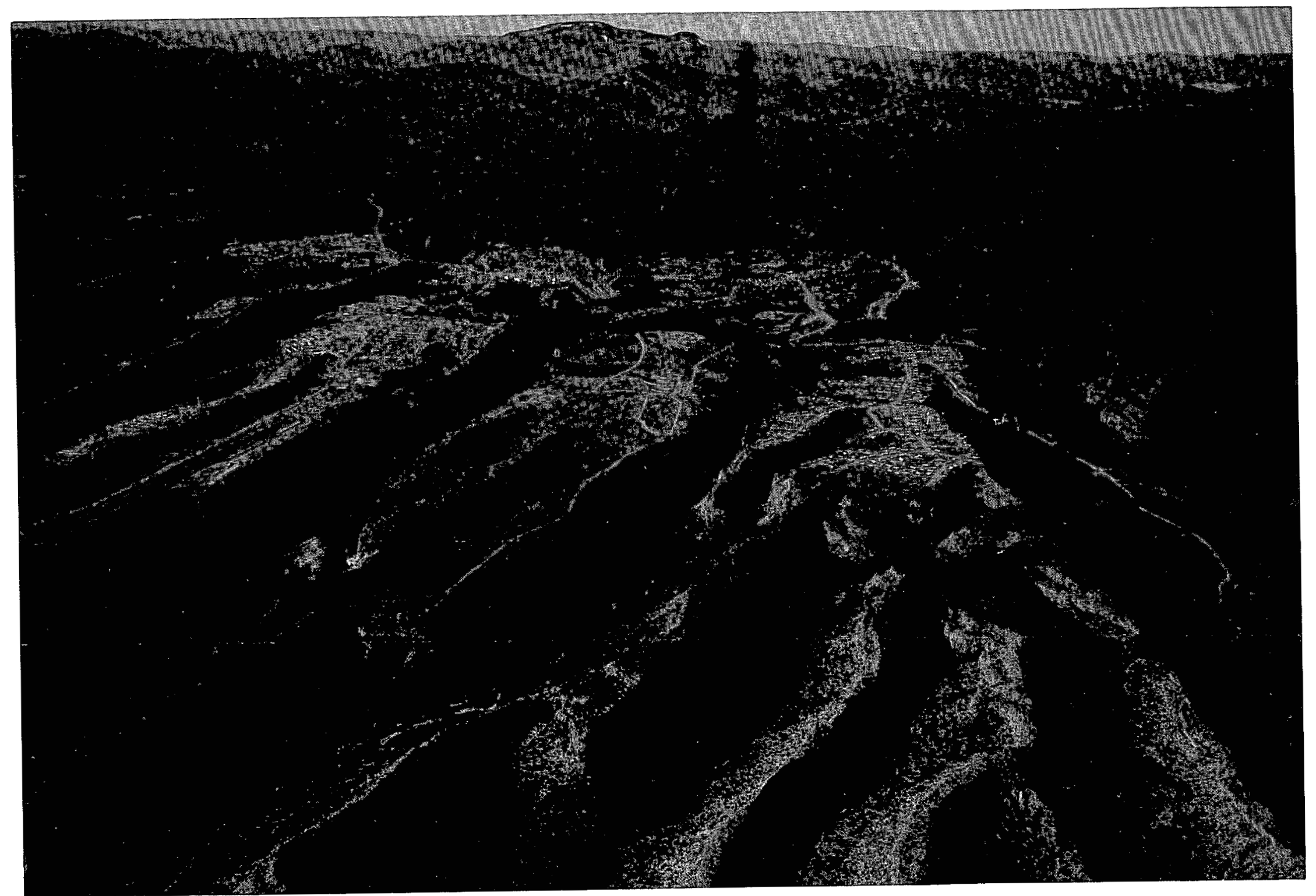

Fig. 1.

A portion of the Pajarito Plateau. This view shows only the northern part of the survey area but it illustrates the nature of the mesas that stretch eastward from the Jemez Mountains. 
Hundreds of pre-Columbian Indian dwellings and villages lie on the mesas (also called mesitas) of the Pajarito Plateau, and the purpose of the survey was to prepare a map (Fig. 2) to show the locations of the sites within LASL lands. With this map, LASL construction planners will be able to avoid ruins or concentrations of ruins and thus eliminate, or sharply curtail, the need for salvage excavations in advance of construction. This archaeological inventory is made in accordance with Public Law 93-291. The area involved extends from Guaje Canyon on the north to Frijoles Mesa on the south.

As the principal purpose of the survey was to locate and identify ruins that might be destroyed or damaged by future construction, the search was concentrated on the mesa tops. No particular effort was made to locate groups of cavate rooms. Therefore, several assemblies of cavate rooms, particularly in the old Otowi section of Bandelier National Monument, are neither shown on the map nor listed among the sites located. These sites are out of range of any probable construction and are readily recognizable.

From 1950 until his death in 1971, Frederick C. V. Worman served as LASL archaeologist, made surveys in advance of construction, and excavated when necessary. Results of some of his work have been published (Worman 1967, Worman and Steen, in press). Results of other Worman excavations and notes on the sites he surveyed are included here.

The sites that Worman surveyed which are listed in the LASL Engineering Department land surveys are included in this report, so both metric and English systems of measurement are used here. Worman's work, and the surveys and drawings by the LASL Engineering Department were done in the English system, whereas I have used the metric system. As the two systems are kept separate in the text, it is hoped that they will not confuse the reader.

\section{ARCHAEOLOGICAL INVESTIGATIONS FROM 1880 THROUGH WORLD WAR II}

The first serious archaeological work on the plateau was that of the Swiss-American Adolf Bandelier. During his studies at Cochiti in the 1880s, Bandelier made five visits to Rito de los Frijoles and went to Puye while on a visit to San Juan. His in- terest was primarily enthnological, but he took notes on the ruins and measured and sketched some of them (Bandelier 1890-92; Lange and Riley 1966).

Following Bandelier's investigations there was a brief lull; then, in 1896, Edgar Lee Hewett (1904) made a rather cursory survey of the Pajarito Plateau from Puye to Frijoles Canyon. Hewett, at that time a teacher of classics at Colorado Normal School, became intensely interested (everything he ever did was done intensely) in American, and particularly in Southwestern, archaeology. From 1898 until 1903, he taught classics and archaeology at New Mexico Normal School at Las Vegas; then he went to Germany for graduate study. On his return to the United States, he settled in Santa Fe and helped establish the Museum of New Mexico and the School of American Archaeology (now the School of American Research). Later, he was instrumental in starting the Department of Anthropology at the University of New Mexico.

Although Hewett was not involved directly in later studies of the Pajarito Plateau, his was an important part in the development of anthropological and archaeological research in the United States. $\mathrm{He}$ was also an ardent conservationist, and, with Professor Byron Cummings of the University of Utah (later of the University of Arizona), argued stongly for an American Antiquities Act. Hewett helped to write the bill that was introduced into Congress by Congressman Lacey of Iowa, and in 1906 the Act for Preservation of American Antiquities was passed and signed into law (34 Stat L. 225).

As soon as the Act was passed, Hewett urged establishment of several National Monuments in New Mexico. Nine Monuments were created in the Territory by Presidential proclamation, as was authorized by the Act. Hewett tried for years to persuade the Federal Government to create a reservation to be called National Park of the Cliff Cities (Hewett 1916) or Pajarito National Park, which would have included almost the entire Pajarito Plateau. An Act of Congress is necessary to creste a National Park, and interest in the project was never great enough to see it through. In 1916, another proclamation established Bandelier National Monument, a smaller version of the proposed park.

During these years, the School of American Archaeology (which then served as the "operations" 


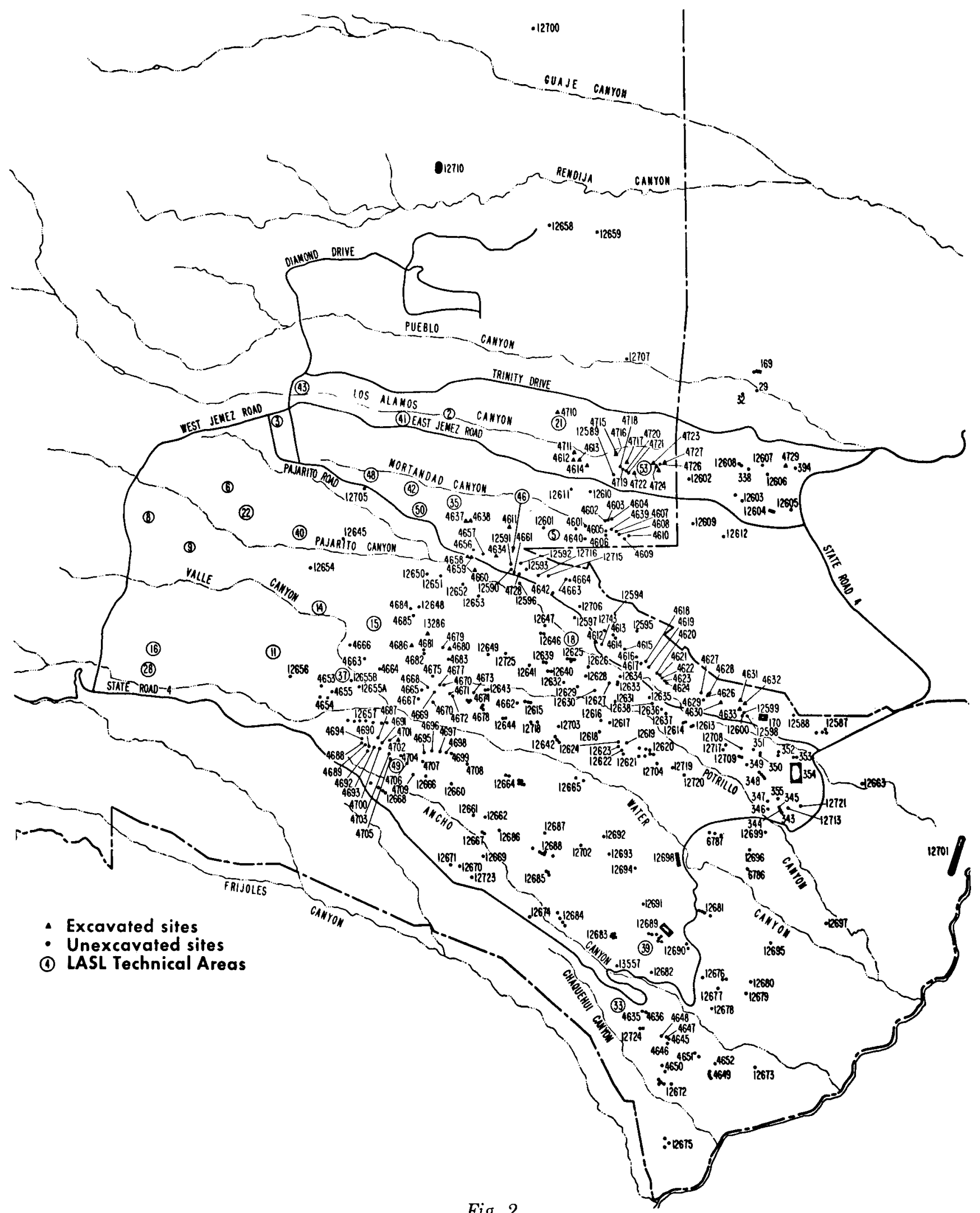

Fig. 2.

Pre-Columbian Indian sites within and adjacent to LASL lands. All sites are recorded in the system of the Laboratory of Anthropology, Museum of New Mexico, and the numbers should have the prefix LA. 
branch of the Museum of New Mexico) ran a series of summer excavations at several locations on the Pajarito Plateau. Here, a number of men and women who were to become prominent in American archaeology received their first field training. The excavations were made at Frijoles Canyon, Tshirege, and Puye. No major reports of these "digs" were written - only a handful of brief papers that were nothing more than summaries of the work. Some of these papers are listed in the Bibliography (Hewett 1904, 1906, 1909 a-d; Chapman 1916, 1917, and 1938). One of the first sound studies of preColumbian puebloan ceramics (Kidder 1915) also stemmed from the School's activity in this period.

During the summers of $1915-17$, Mrs. L. L. W. Wilson of the Philadelphia Commercial Museums excavated a major part of the ruins of Otowi. This was a joint venture of the Museums and the School of American Archaeology, and the artifacts recovered are in the Museum of New Mexico. Only two brief papers, 12 pages in all, were published to describe that major excavation (Wilson 1916, 1918).

Between the two World Wars, little work was done on the Pajarito Plateau. A number of small sites were dug, without benefit of Antiquities Act permits, and no reports were published. In 1935, the National Park Service surveyed the ruins on the Ramon Vigil Grant - essentially the same area as that covered by the present survey. The 1935 survey was made by a forester, a map was made, and then the field book was lost, so the total result is a map of about 200 site locations.

After the development of dendrochronology as a means of dating ruins, there was a flurry of woodcollecting activity throughout the Southwest. Ruins on the Pajarito Plateau were searched for beam specimens; the Laboratory of Anthropology, at Santa $\mathrm{Fe}$, sponsored most of the collecting in northern New Mexico. Several papers, published around 1935, gave dates for sites from Puye to Frijoles Canyon, but these dates, published while dendrochronology was being developed, are not reliable. A more recent report (Robinson et al. 1972) summarizes the early work and gives firmer dates derived from re-study of the beam material.

At Bandelier National Monument, several small excavations were made as part of ruins stabilization projects. Manuscript reports were made, and a few were published (Lister $1940 \mathrm{a}$ and b; Hendron 1940,
1946). The manuscript reports are on file at the Monument and at the National Park Service headquarters in Santa Fe.

\section{Post World War II Work}

Beginning in 1948, Frederick C. V. Worman then at Adams State College, Alamosa, Colorado, dug the small site in Frijoles Canyon which he named Rainbow House (Caywood 1966), listed in the Museum of New Mexico survey as LA 217. In 1950, the last year of his association with Adams State, he also dug three trenches in the large plaza site, LA 4693, within LASL lands, but prepared no report. In the autumn of 1950, Worman joined the LASL staff and, in addition to his regular duties, made archaeological surveys and excavations in advance of construction.

Between 1946 and 1950, small excavations associated with ruins stabilization were made by National Park Service (NPS) people at Tyuonyi and other sites in Frijoles Canyon. Manuscript reports were written, and copies are filed at NPS offices, but nothing was published.

The community of White Rock was built in an area containing a number of old Indian sites, and intermittently between 1953 and 1956 the Los Alamos Archaeological Society excavated a site designated Fulton 190 (Fulton was in charge of the NPS survey in 1953). The Laboratory of Anthropology gave the site the number LA 8681 , but it is commonly referred to by the Fulton number. The work was done under an Antiquities Act permit issued to LASL, with Frederick Worman as archaeologist. Worman gave nominal supervision and direction to the excavations. Two mimeographed reports on the dig were prepared (Fretwell 1954, 1959). Later, James Maxon of the NPS staff summed up the data from this site and from another excavation (a cavate room group at Tshirege, LA 170) carried on by the Society (Maxon 1969).

During this time, Worman surveyed 129 sites and located them on LASL's 1:50 topographic maps. He also was called on from time to time to excavate sites that were to be destroyed by construction. One cluster of four sites that he dug was on Mesita del Buey (Worman 1967). He excavated 11 sites at the Meson Physics Facility location. Mr. Worman had compiled some of the data on the latter work for a 
report at the time of his death; these data have been assembled with other information for the report on Mesita de Los Alamos (Worman and Steen, in press).

In addition to the excavations just mentioned, Worman dug at least 13 other sites on the Pajarito Plateau between 1950 and 1969. Excavation notes and other bits of information on these sites, as well as summary reports of work at other sites by different persons, are presented as an appendix to this report.

The sites that Worman surveyed and those listed in this recent survey have all been recorded in the state-wide archaeological survey of the Laboratory of Anthropology of the Museum of New Mexico. The prefix "LA" before a site number indicates the Museum list, not "Los Alamos."

\section{THE SURVEY}

\section{A. The Natural Environment}

The higher elevations of the plateau support a forest of ponderosa pine; at about $2100 \mathrm{~m}(7000 \mathrm{ft})$ this yields to piñon and juniper woodland. The latter is dense near the pine forest, but below about $1970 \mathrm{~m}(6400 \mathrm{ft})$ it becomes scattered and there are large areas in which sagebrush, rabbitbrush, salt brush, and cholla cactus form the dominant ground cover. At the lower elevations, sage and cholla frequently serve as indicators of ruins; they grow luxuriantly on the rich soil of the former habitation sites.

The Pajarito Plateau is composed of a series of Pleistocene ash flows and ash falls of Bandelier tuff. These lie on sedimentary and volcanic rocks of Middle Miocene to Pleistocene age (Purtymun and Kennedy 1971).

Purtymun and Kennedy (ibid. pp. 6-7) say of the soil on Mesita del Buey: "the soil cover is 3 to $4 \mathrm{ft}$ thick along the axis of the mesa and thins toward the canyon rims where the tuff is exposed. The light brown, clay-like soil is derived from weathering of the tuff. The primary soil constituents are quartz and feldspar with the clay minerals montmorillonite and illite." Alluvium in some of the stream channels, according to the same authors, is probably no more than $3.4 \mathrm{ft}$ thick, but in Pajarito Canyon it is $20-30 \mathrm{ft}$. thick.
The soils on Mesita del Buey are typical of those on the other mesas searched during the survey. Over much of the area, the soil is less than $1 \mathrm{~m}$ thick and at numerous spots where trenches or pits have been dug down to the tuff stratum, the soil is only a half meter or less thick. It always feathers out to nothing near the mesa rims.

\section{B. Settlement Pattern}

As the survey proceeded, some patterns of site location and associations became apparent. First, nearly all sites were on crests or slight ridges on the mesa tops. This was an obvious arrangement to ensure the builders of adequate drainage at and near the houses.

Second, elevation appears to have been an important factor in determining the extent of population spread on the mesitas. On some of them, houses

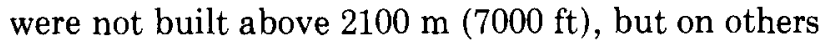
dwellings are to be found above $2200 \mathrm{~m}(7300 \mathrm{ft})$. The explanation for these limits of occupation seems to be the length of the growing season. Localized air currents probably give a few more frost-free days at higher elevations on some mesas than on others.

Late in the 13th century, at the beginning of intensive occupation of the Pajarito Plateau, the population seems to have been pretty evenly spread on the mesitas. By the latter part of the 14th century, the Indians tended to build larger housing units and to live at somewhat lower elevations. Then, by the 15 th century, the small farmsteads and villages appear to have been abandoned and the population was concentrated in the large settlements such as Tshirege, Tsankawi, and Otowi and in villages clustered around plaza sites.

None of the Pajarito houses or villages, large or small, seems to have been fortified against human enemies.

\section{The Archaic Period}

Archaic projectile points have been found sporadically on the Pajarito Plateau. A number of points that can be classified as San Jose (Bryan and Toulouse 1943), as well as large corner-notched points in the archaic tradition (Dick 1965, IrwinWilliams 1967), also have been collected from the 
surface. No evidence of settlement in those early days has been recorded, and we must assume that hunting parties went onto the Pajarito Plateau but made no permanent camps.

Most of the archaic points closely resemble Dick's Type 5. At Bat Cave, most were found in levels that yielded pottery, but they also were found in the preceramic horizon. Irwin-Williams indicates that stemmed and barbed dart points of this nature appeared in the southwest about 1000 B.C.; they persisted until the advent of the bow and arrow about A.D. 700. The points are typical of late archaic times.

Two projectile points found on the surface of Mesita del Buey are shown in Fig. 3. One came from a slope west of the water storage tank on Rex Drive; the other from approximately $100 \mathrm{~m}$ east of the tank. The point on the left is a blue-gray chert of unknown origin; that on the right is agatized dolomite - the so-called Alibates flint of the Texas Panhandle. These are typical of archaic points found on the plateau and in private hands; no artifacts of that age were found during the survey.

A single fragment of a Folsom point was found several years ago on the mesa north of Ancho Canyon. The point was made of a fine chalcedony or carnelian - not a local stone. As far as I know, this is the only artifact from before the Archaic period found on the plateau.

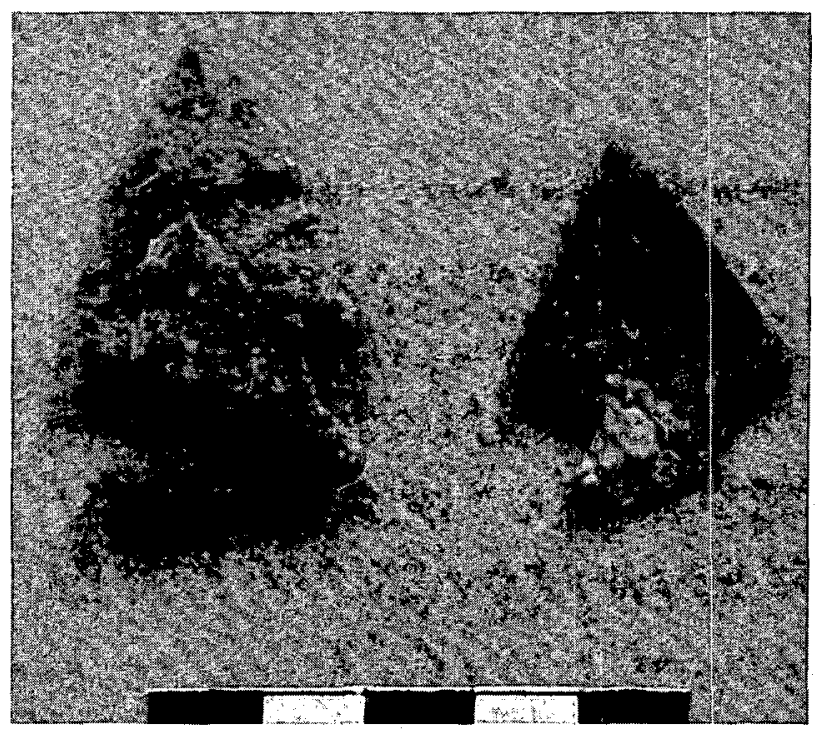

Fig. 3.

Archaic points from surface of Mesita del Buey (centimeter scale).

\section{Pueblo Indians on the Pajarito Plateau}

It was probably late in the 13th century that the unpopulated Pajarito had an influx of puebloan settlers. The mesitas soon had a sprinkling of house blocks which, from their size, must have housed family groups. These small settlements extend from the rim of the White Rock Canyon of the Rio Grande up to about $2400-\mathrm{m}(7400-\mathrm{ft})$ elevation. Their greatest concentrations are at 2150 - to $2350-\mathrm{m}$ (6600- to $7200-\mathrm{ft}$ ) elevation, and it must be that the mesa top environment at that elevation offered optimum conditions for primitive horticulture. The houses are to be found along the crests of the mesitas, where drainage is best.

All farming must have been done on the mesa tops, for in the district where sites are clustered most thickly the canyons are narrow and deep and contain little arable land. The small, level canyon bottom areas large enough to support a corn field probably were not used because the canyon bottoms are very chilly during the winter and the growing season would be too short for crops.

With the houses centered on the mesa tops and, presumably, the fields planted there also, the rnesas must soon have been stripped of all vegetation except for the crops and those annuals that grow as weeds in disturbed soils.

It would be foolish to attempt a population estimate, but it must have been fairly small perhaps a few dozen persons on a mesita, living in several small house blocks spread along the mesita top. From the evidence available (numerous small houses and thin, small midden areas), one must assume that the house blocks were occupied for only short periods - a generation or less. This is a common occurrence in primitive communities, where there are many reasons why people move from one location to another - death, bad luck, or evil spirits plaguing the house. Nearly all the houses excavated within the survey area had been "cannibalized;" roofing timbers and most of the stone had been removed for reuse at another location.

The predominant painted pottery found on the surface at these small sites is Santa Fe Black on White which has been dated at A.D. 1225-1350 (Stubbs and Stallings 1953). Occasional sherds of Galisteo Black on White, 1300-1400, and St. John's Polychrome, 1100-1250 (Smiley et al., 1953) are found in them and, rarely, some Wiyo Black on 
White, 1300-1400 (Breternitz 1966, Smiley et al. 1953). This indicates that these small farmsteads were probably occupied between 1250 and 1350 .

At some unknown time, these little settlements began to grow, and the usual pattern for house blocks then became a double or triple row of rooms, aligned north-south, like LA 4632 (Worman 1967) and LA 4729 (Worman and Steen). The most common painted pottery at the two sites of this type that Worman excavated is a mixture of Santa Fe and Wiyo Black on White.

A further development was to extend one or two rows of rooms eastward from the north-south room blocks. This created a plaza, and in the plaza there was often a kiva - the earliest appearance of the circular, detached kiva on the Pajarito Plateau. At these sites also, the common black on white pottery types are Santa Fe and Wiyo. Rainbow House in Frijoles Canyon (Caywood 1966) was a site of this sort.

About the time that the biscuit wares (Kidder 1915) began to be made, in the latter part of the 14th century (Breternitz 1966), several changes occurred in the settlement patterns and, apparently, in the religious practices of the people of the Pajarito Plateau.

First, the high elevations seem to have been abandoned and the population congregated on the lower (eastern) parts of the mesitas. This move may have been because of a climate change that caused a shorter growing season on the mesa tops, but it seems more likely that the lower, wider parts of the canyon bottoms, with alluvial soil, were cultivated for the first time. Check dams across minor drainage channels in the canyon bottoms and on the mesa tops appear at this time. Few sherds were found near these water retention devices, but those found were consistently of the biscuit wares and early glazes. This also seems to be the period at which the heat-retaining properties of basalt exposures were put to use for garden plots, as at LA 354 and LA 12698.

The well-known large sites, Tshirege, Otowi, and Navawi, probably were started at this time. These are large house blocks built around open plazas that face south. Another apparently contemporary development was the construction of villages associated with a rectangular house block built around a plaza that sometimes had a narrow entry on the east side. LA 12609 and LA 12700 (Fig. 4) are typical of these plaza sites. Also see Fig. 9.

Apparently at the time the larger villages were constructed, the people also began to dig the cavate rooms in southward facing cliffs on the Pajarito Plateau. The cavate rooms, many of which seem to have been ceremonial, and the attendant masonry rooms built on the talus slopes of the canyon walls all seem to belong to the same period as the larger villages.

One other aspect of culture on the Pajarito Plateau that seems to belong to this period is the pictographic art applied to the canyon walls and to the interiors of many cavate rooms. During the survey, no examples of rock art were found in association with any sites except those of the late period.

Stallings (1937) wrote, on the basis of the dendrochronological record, that the Pajarito Plateau was abandoned late in the 16th century. The revisions now available (Robinson et al. 1972) show that the last cutting dates of roof timbers on the plateau might have been a little earlier, possibly about the middle of the 16 th century. This does not mean that the Indians quickly packed their bags and left en masse early on a September morning. The exodus and relocation in the valley probably took place over several years and could have been caused by any of several reasons - the most likely being exhaustion of the soil through poor farming methods and a drought that Stallings shows to have occurred in the upper Rio Grande Valley during the last half of the 16 th century.

After the 16th century and after Spanish occupation of the Rio Grande, there seems to have been some slight Indian use of the plateau. In one of the cavate rooms (a probable kiva) of Ruins Group M in Frijoles Canyon, there are two pictographic figures that strongly resemble horses (Fig. 5). The nature of the kiva indicates more than just casual occupation, and it seems probable that a small community was in residence at some time during the historic period. However, no such evidence has been found in the survey area, except for the horse and rider in White Rock Canyon (Fig. 6).

A second indication of post-16th century use of the plateau by Indians is the presence of game pits. It is highly unlikely that the pits were in use while several hundred Indians were busy farming and carrying on other activities of agricultural life on and around the mesas. It would have to be after the 


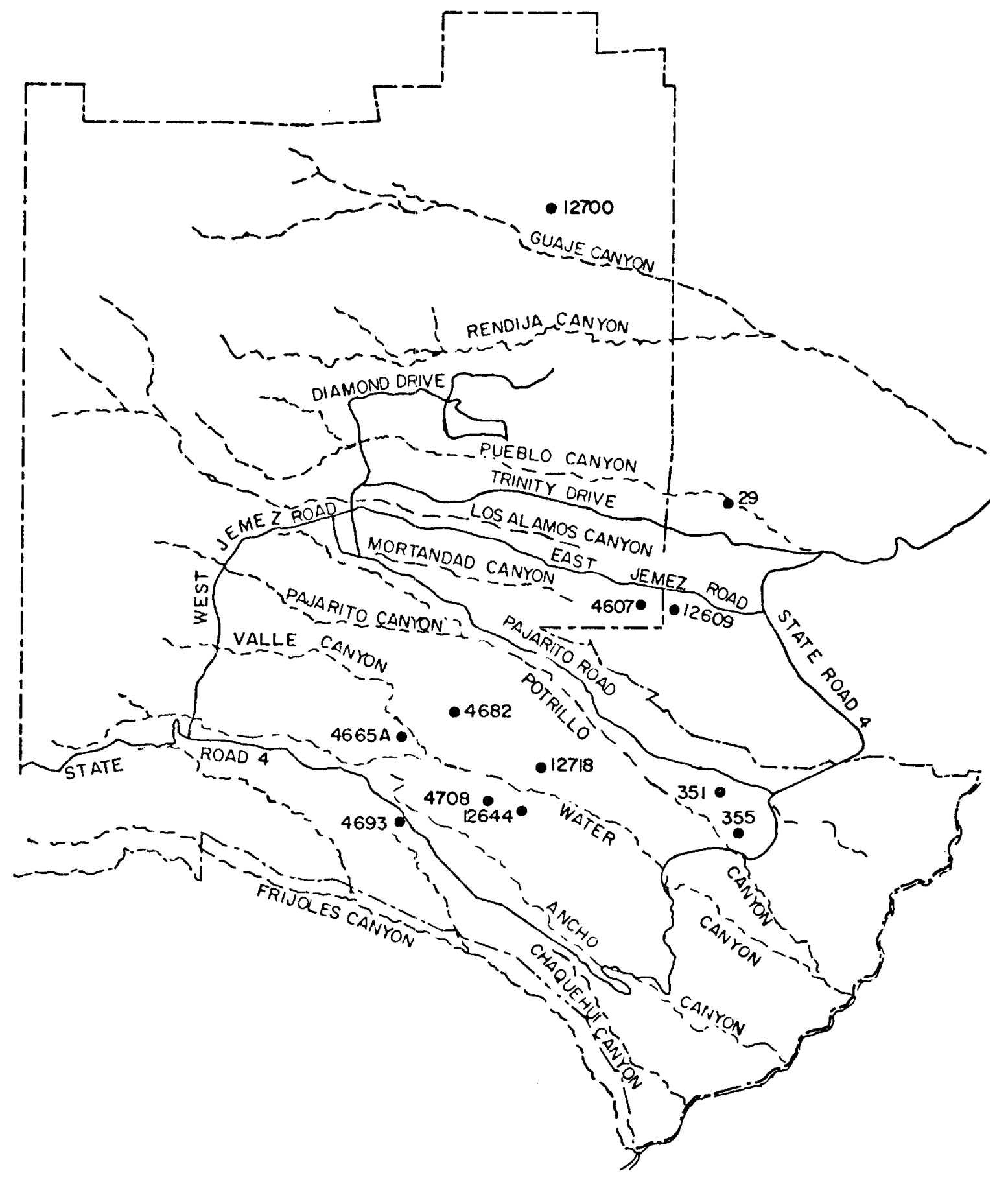

Fig. 4.

Plaza sites. 


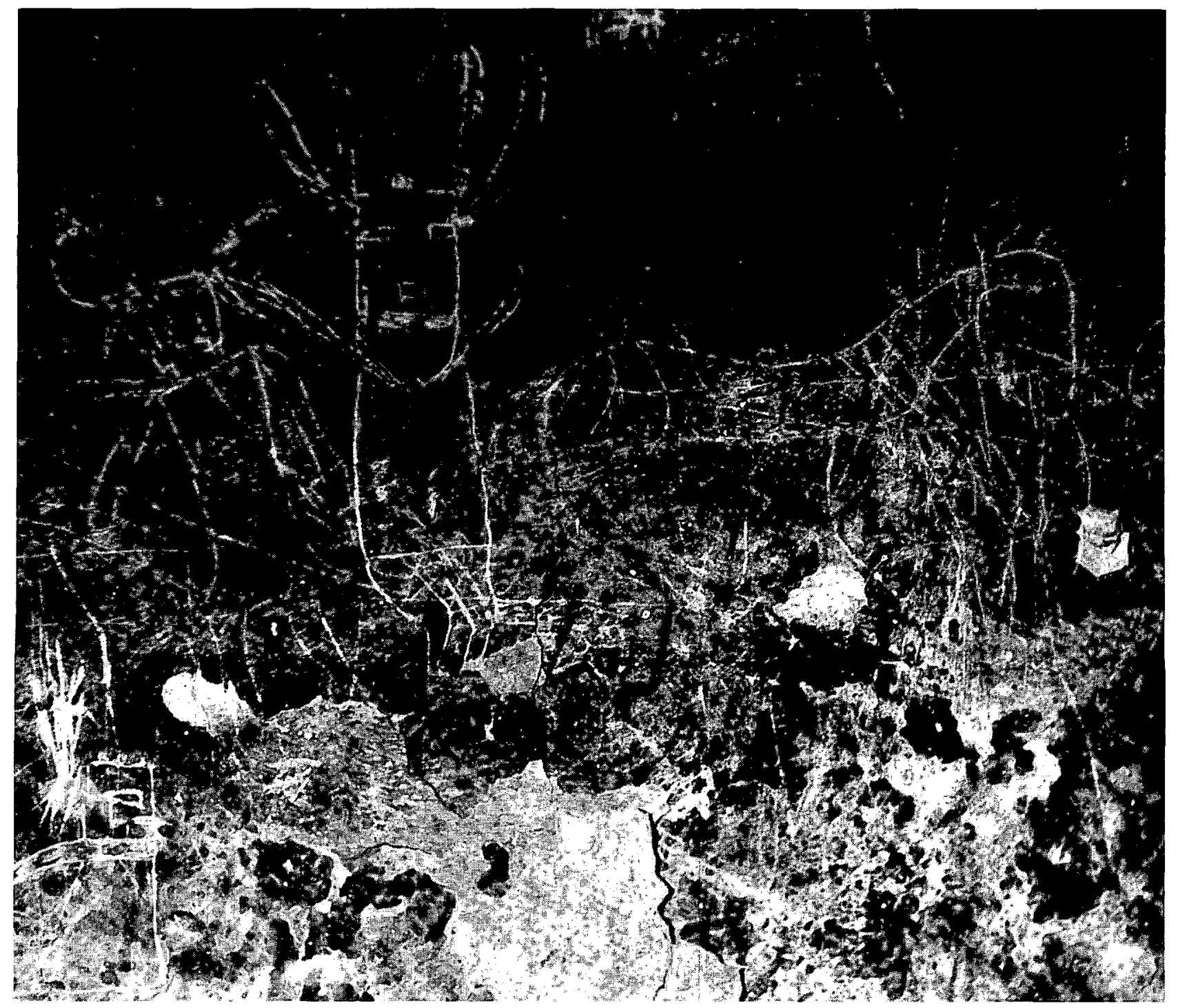

Fig. 5.

Probable historic period rock art in a kiva at Bandelier National Monument.

villages were abandoned and the natural plant and animal populations were once again established that deer could be hunted and eagles trapped. Mention is made of old brush wing walls at the deer trap at Navawi which seemed to be of the late 19th or early 20th century. Finally, the Tewa of San Ildefonso consider a part of the Pajarito Plateau which adjoins the LASL lands to be a sacred area. There are few recognizable shrines on the land, and we do not know just how the area is used; apparently, some rites are performed there at the present time, and burials are made there.

\section{E. Kinds of Sites}

The earliest structures on the Pajarito Plateau were small farmsteads of from two to ten rooms. Ruins typical of this sort of dwelling are LA 4630, LA 4722 , etc., described in the appendix. They almost always were constructed of puddled adobe.

Rooms were aligned in one or two rows, and the long axes of these structures were almost invariably north-south. To judge by the dwelling rooms, which contained firepits, a family used two to four rooms, one for living quarters, the others for storage. One 


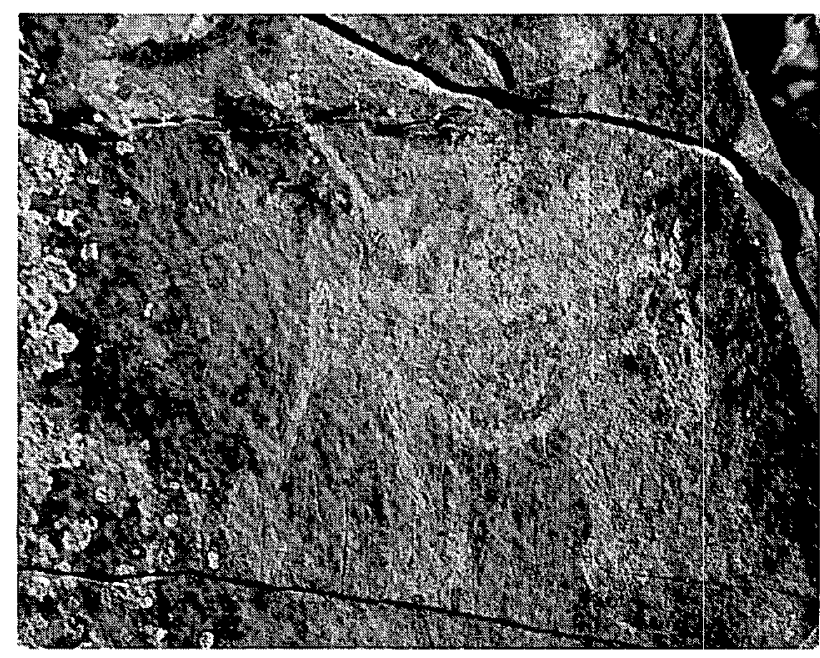

Fig. 6.

$A$ horse and rider on basalt at the lower end of Pajarito Canyon.

must assume that families using these small dwelling units were closely related.

Ceremonial rooms, or kivas, are not always present at these small sites. No true kiva has been reported from sites in the survey area at which Santa Fe Black on White is the predominant pottery, although Snow (1974) did find one in Frijoles Canyon. More commonly, one room, a little larger than the others, and usually on the east side of the building, had a curved wall. Excavations in such rooms usually reveal one or more kiva features, such as ventilator, deflector, or extra large firepit. It is probably a misnomer to apply the term kiva to the ceremonial rooms of these farmsteads. It is seldom that all the features associated with the kivas of the San Juan Basin are found in them.

There is rarely any evidence of ground level doorways in these structures, even through partition walls. Entrance to the rooms must have been by ladder through a hatch in the roof. The vents in walls which are peculiar to the upper Rio Grande were frequently made. These were round openings that varied from about 12 to $20 \mathrm{~cm}$ in diameter, and most were plugged with wads of mud or truncated cones of tuff (Fig. 7). The vents were made at varying heights and positions in the walls (sometimes several in one wall), and no good explanation for their purpose has yet been given.
Structures of this type are almost always associated with Santa Fe Black on White pottery and must be dated to the late 13 th or early 14 th centuries. At a few small sites on lower elevations of the plateau, Wiyo Black on White, biscuit wares, and micaceous plain wares are found at house blocks of this sort, so it is evident that occupation of small houses did not cease when the local population began to cluster into larger settlements.

\section{F. Middens}

As can be expected, midden deposits at these small sites are thin. Trash was thrown anywhere in the vicinity of the house, and later additions to the structure usually were built on midden material. Trash deposits are generally most abundant on the east sides of buildings, which probably means that that side, sheltered from the prevailing southwesterly winds, was where most of the farnily's work was done.

\section{G. Expansion of the Small Sites}

Given the plans of the small sites just described, expansion of the miniature communities naturally followed in the same line. Small villages of two, three, or four rows of rooms such as LA 4729, Fig. 8, were constructed.

These larger structures seem to have replaced the small farmsteads late in the period when Santa $\mathrm{Fe}$ Black on White pottery was made. Pottery found at these sites runs heavily to Santa Fe Black on White, but later wares are also found, Abiquiu and Bandelier Black on Gray, and a few sherds as late as Glaze I. (See the sherd count for LA 4729, Worman and Steen, in press.)

As at the small sites, almost all these structures seem to have been only a single story high. Only rarely does the height of the mound suggest a second story. Also, most construction at these sites seems to have been of stone laid up with adobe mortar. Walls built of masonry of shaped stone blocks first appear at this time. Walls of adobe in the older style continued to be built, and walls of all three kinds of construction generally are to be found in any site of this type. 


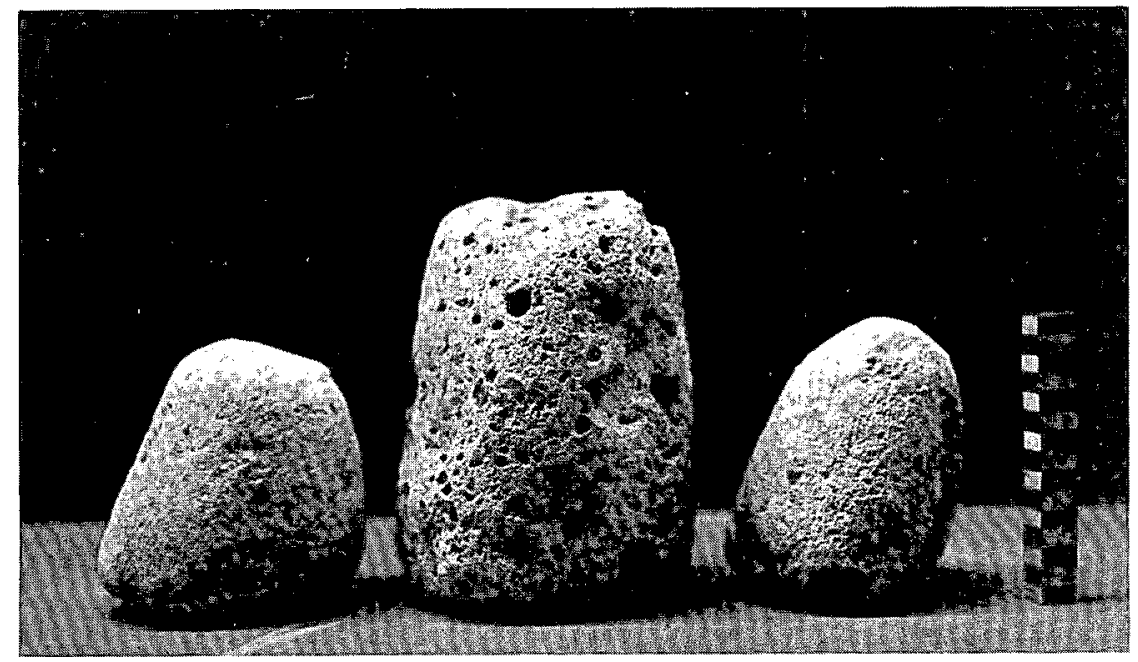

Fig. 7 .

Tuff vent plugs (centimeter scale).

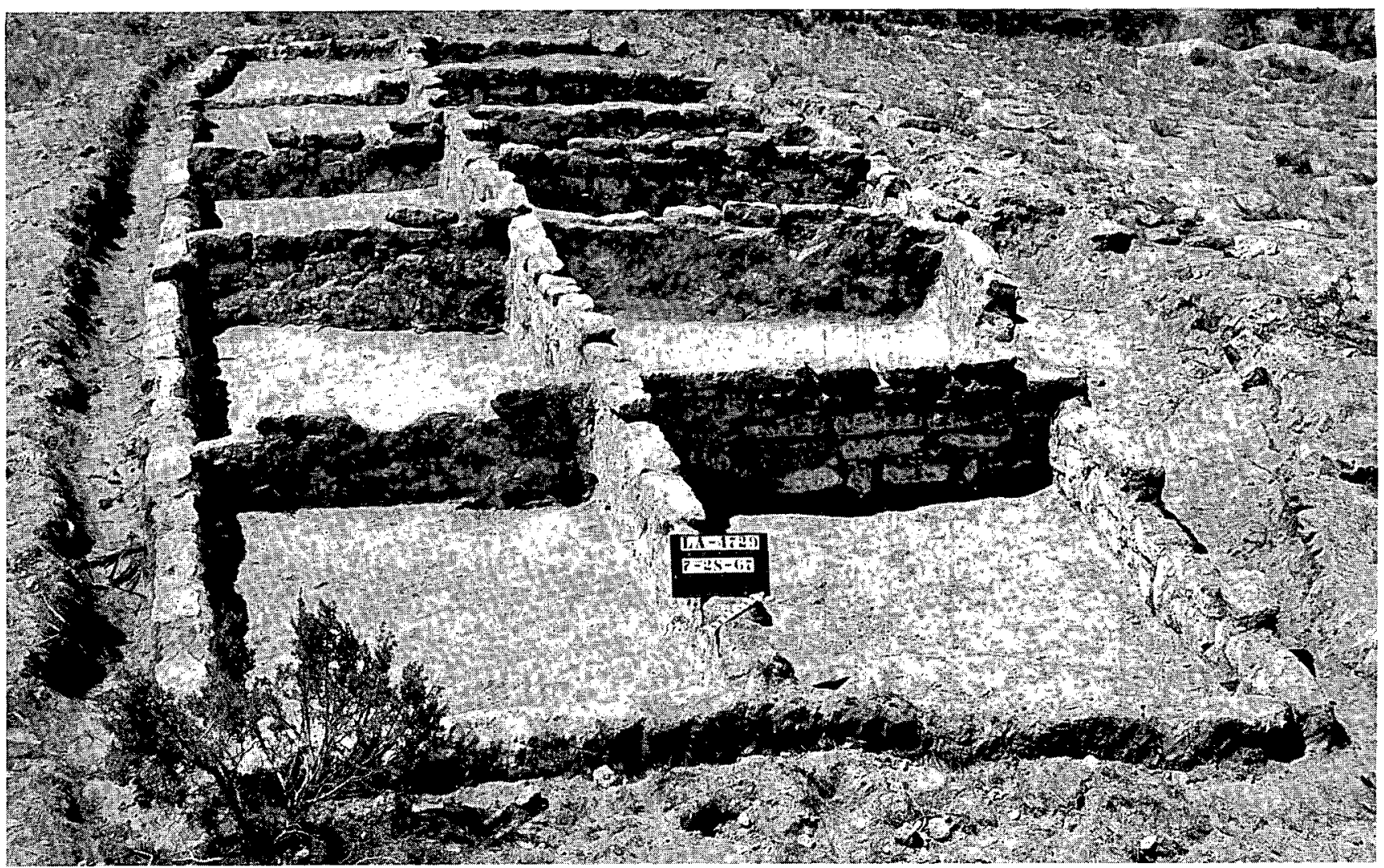

Fig. 8.

LA 4729 in Los Alamos Canyon, excavated by Worman in 1967. 


\section{H. Plaza Sites}

It was probably late in the 14th century that the Pajarito Plateau people began to gather in villages that consisted of clusters of house blocks with one dominant building, a two- or three-story structure built around a plaza. This building generally was highest on the west side, and frequently there is an indication of a rather narrow entry (ceremonial?) into the plaza through the east side. A kiva was a feature of the plaza, and in nearly every instance a second kiva was dug east of the structure and south of the entry (where a passage can be detected). The mounds that remain at this type of site measure as much as 30 by $70 \mathrm{~m}$, and the long axis invariably runs north and south. Sites LA 4693 and LA 12609, whose ground plans are shown in Fig. 9, are typical of these sites. However, aside from the fact that there were kivas in the plazas, there was no standardization. LA 4665, the PHERMEX site, was built with three plazas with a kiva in each.

Much, perhaps most, of the plaza site construction was done with masonry and shaped blocks of tuff (Fig. 10), and pottery found there indicates that these sites were contemporaneous with the earlier stages of construction at large villages such as Tshirege. Just how this kind of settlement fits into the late pre-Columbian construction pattern in the upper Rio Grande valley is not certain. Viliages with kivas in central plazas and with eastern entries are fairly common; one such was Pueblo Pindi (Stubbs and Stallings 1953), and Tyuonyi in Frijoles Canyon is a large version of this sort of village. The sites in the valley proper, like Pueblo Pindi, extended over much larger areas than those on the Pajarito Plateau. Whether the difference in arrangement of rooms had any significance other than as a reflection of a sparse population on the uplands cannot be determined at this time. The compact plaza sites on the Pajarito Plateau are quite distinctive.

Excavations have been made at only one of the plaza sites within the survey area. In 1950, Fred Worman dug three trenches at LA 4693. Unfortunately, no notes, photographs, or other records of that work have been found.

A few groups of cavate rooms, notably at LA 355 and LA 12712, are located near plaza sites and appear to be contemporaneous.

\section{The Big Sites}

The large sites, Tshirege, Otowi, and Little Otowi, which are within the survey area, and Tyuonyi, Tsankawi, and Navawi, which ase on National Park Service and San Ildefonso Pueblo lands, represent the last major phase of pueblo occupation of the Pajarito Plateau.

The plaza sites must have been contemporaneous with at least the early occupation of the large sites, yet the ground plans of only two of the latter, Tyuonyi and Tsankawi, show plazas surrounded by rooms. The others are all composed of massive house

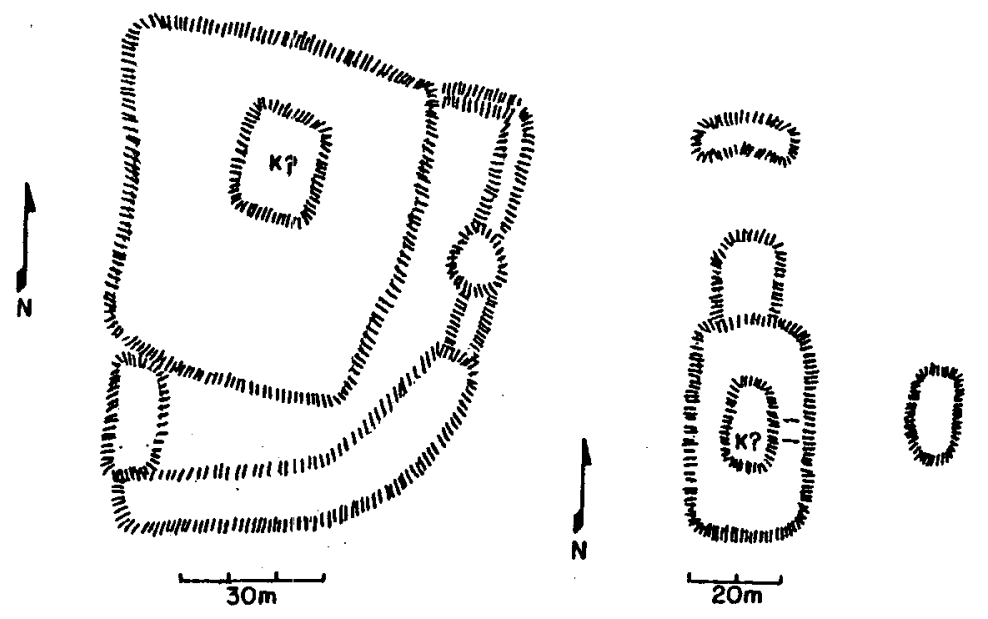

Fig. 9.

Ground plans of LA 4693 (left) and LA 12609. 


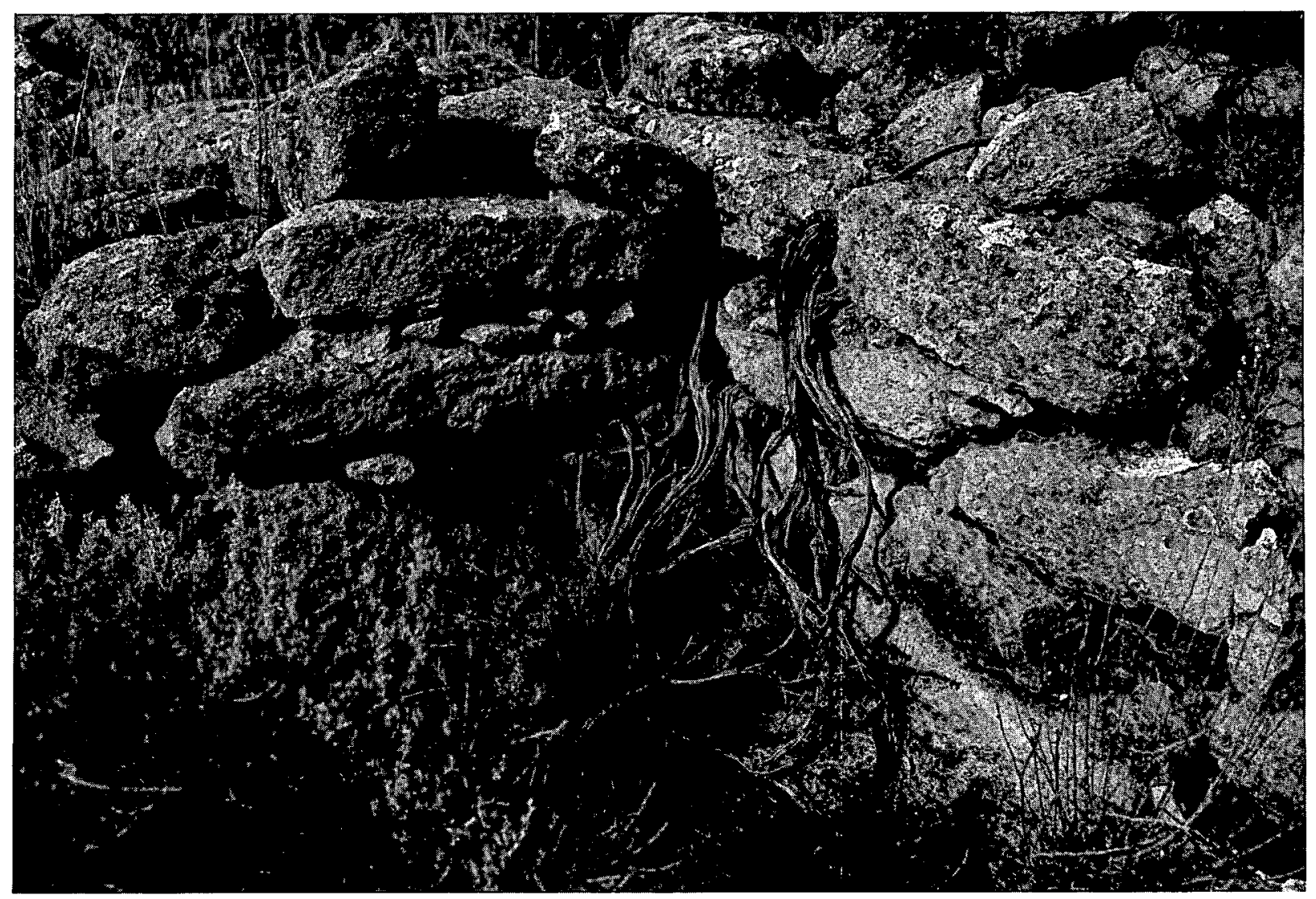

Fig. 10.

Masonry at a small plaza site, LA 4619.

blocks so arranged that they form three sides of plazas that are open to the south.

The big villages are all at lower elevations of the Pajarito Plateau (Tyuonyi at the bottom of Frijoles Canyon). It seems probable that the location of land that could be irrigated or served by water catchment devices had much to do with placement of the sites.

\section{J. Cavate Rooms}

The cavate rooms that are so prominent a feature of many of the Pajarito Plateau cliffs apparently are all of the same period as the plaza sites and large sites like Tshirege. With some exceptions, as in Ancho Canyon, the cavate rooms appear in groups near the late centers of population, and the masonry is of the late type - of shaped blocks of tuff. Pottery at the cavate room sites is scarce. Because these sites have been visible and accessible for years, surface sherds have been carried away by visitors.
The cavate rooms were dug into the soft tuff cliff faces and nearly always were actually the innermost rooms of blocks of masonry rooms built along the cliff bases (Figs. 11 and 12). The outer rooms were certainly dwellings, but in two- or three-story structures the lower and back rooms were used for storage. Many of the cavate rooms, roughly finished and unsmoked, must have been used for storing foods or family utensils and equipment.

Many, however, are well-finished, equipped with niches and firepits, and heavily smoked. A few are large, have kiva features, such as sipapus, loom supports, and ventilators, and are termed cave kivas. The other smaller, smoke-blackened rooms are generally considered dwellings. After looking at scores of these rooms, another function comes to mind - that they were small ceremonial chambers for a family, or, quite possibly, for one man. Some arguments to support this thesis are as follows. 


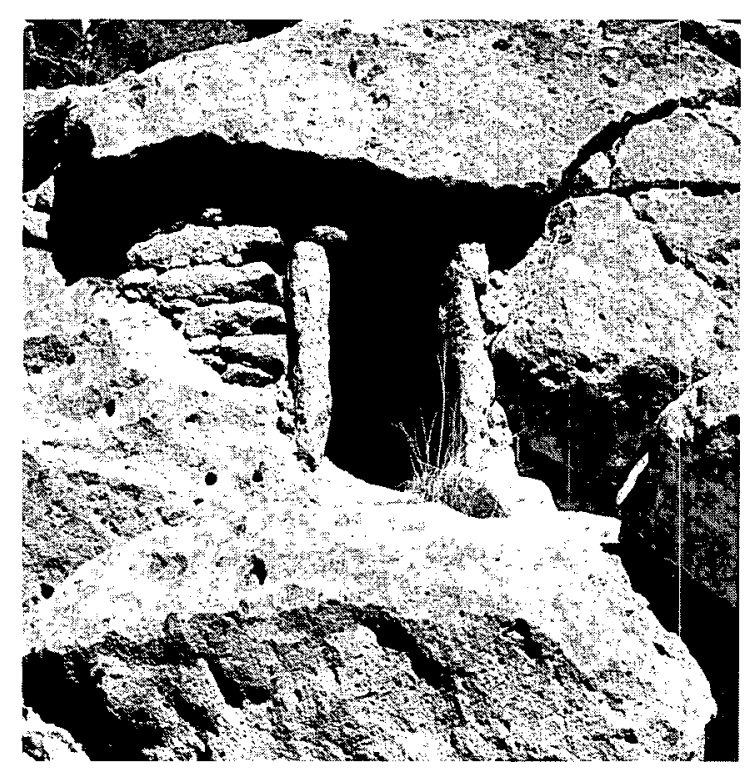

a. LA 12725, a small room with a wellpreserved masonry wall. This isolated room probably served as a shrine.

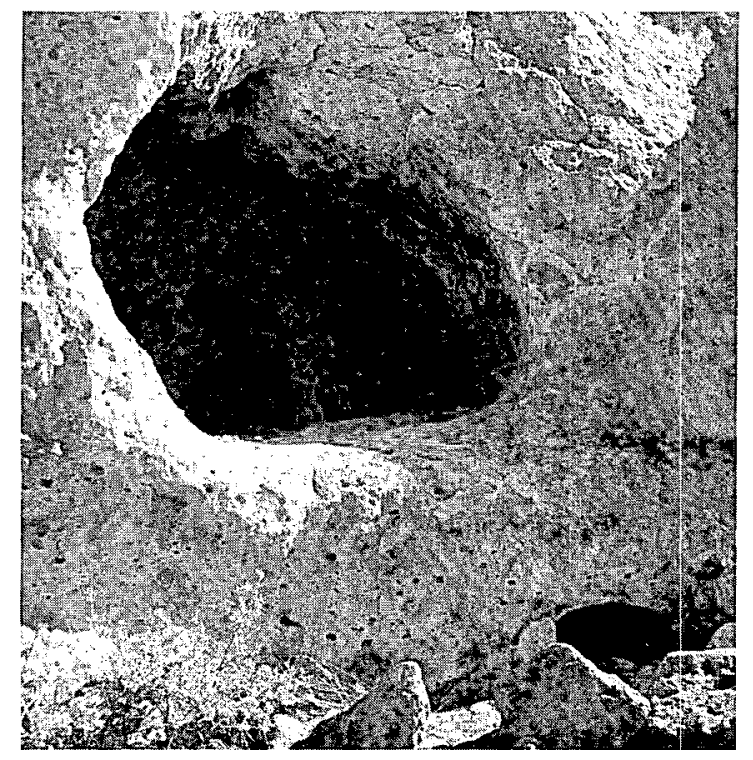

c. A cavate room, probably ceremonial, at $L A$ 12743. The front wall is gone, so the interior shows clearly. There is a large niche at floor level at the rear of the room.

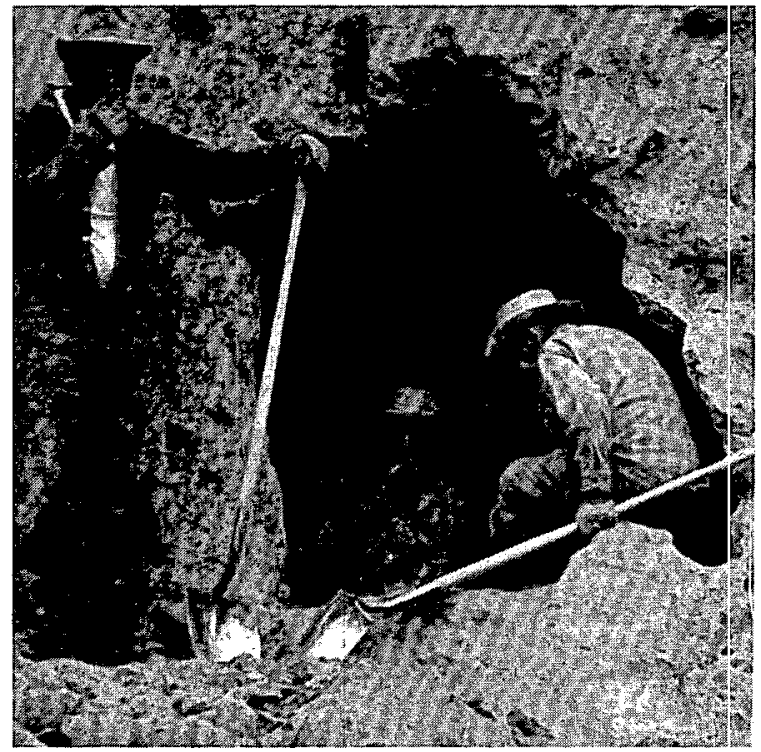

b. Frederick Worman (center) excavating at LA 12743, a group of cavate rooms in Pajarito Canyon.

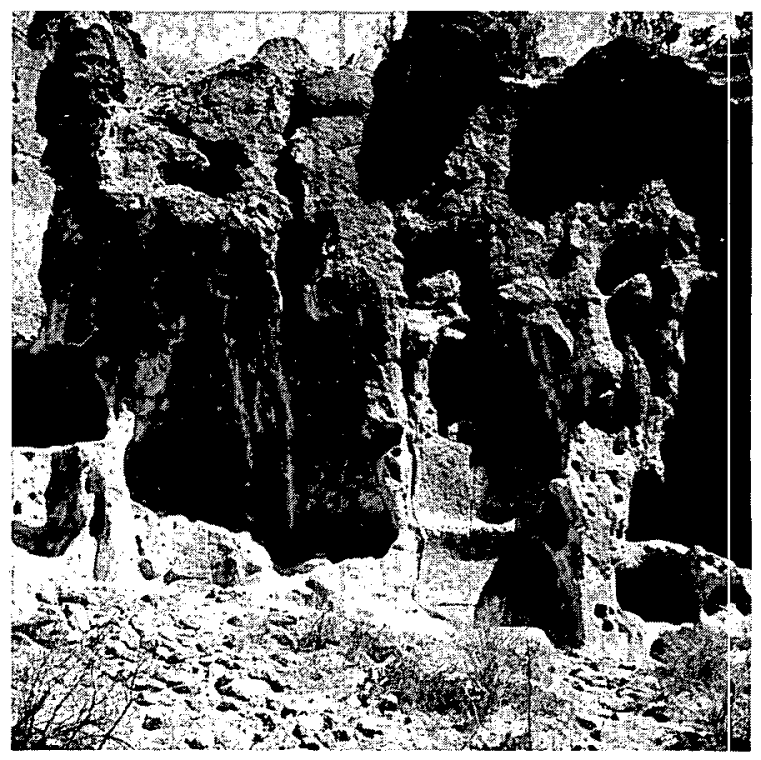

d. LA 13557 in Ancho Canyon. The masonry rooms at the base of this cliff rose three stories high. Six cavate rooms were dug into the tuff at this point; at least two were ceremonial.

Fig. 11.

Cavate rooms. 

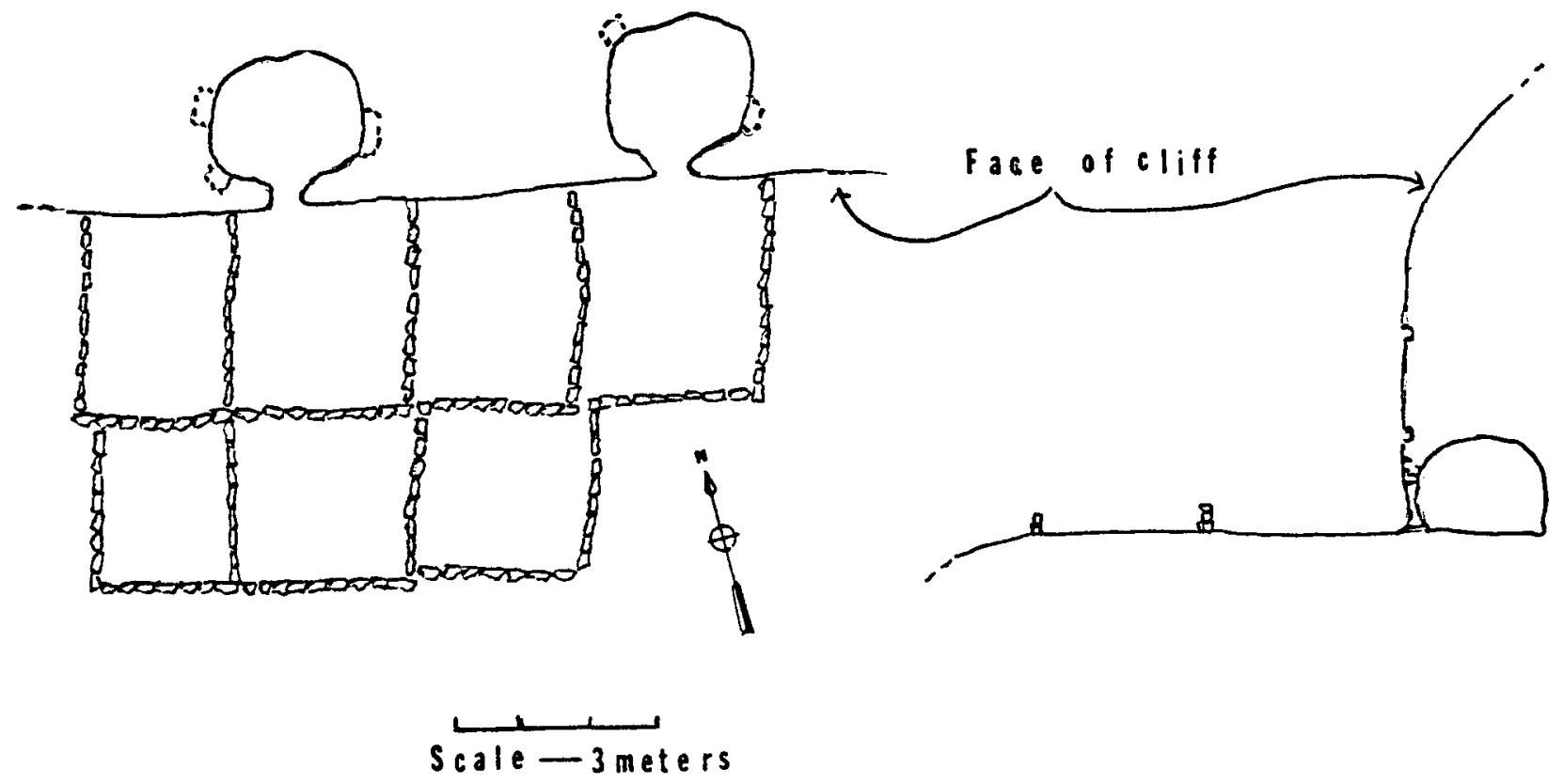

a. Plan (left) and profile of a block of masonry rooms built at the base of the cliff at Tshirege (LA 170) with two cavate rooms dug into the stone behind them. Beam sockets in the cliff face indicate that the surface rooms were two stories high.

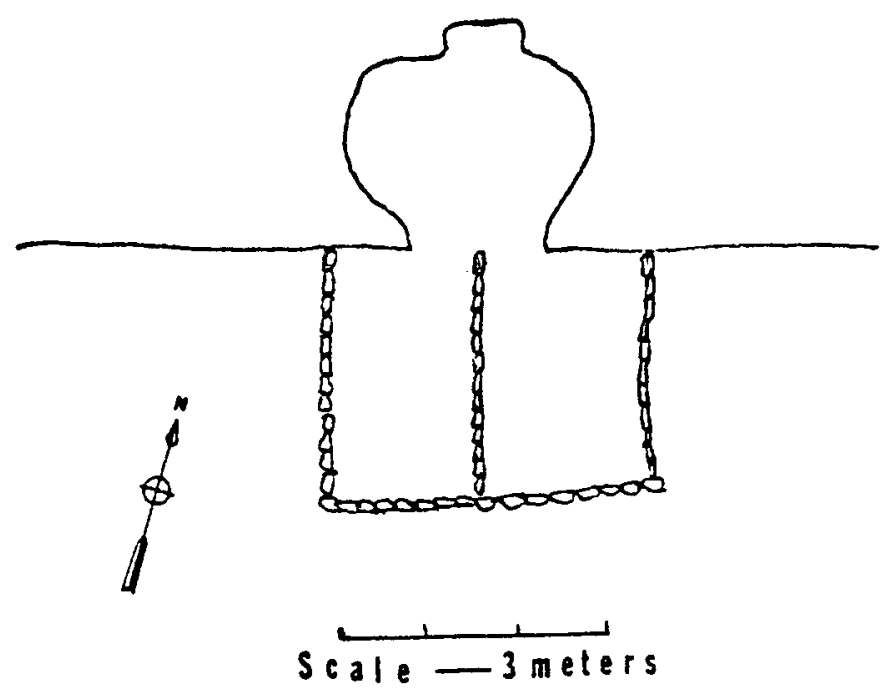

b. Ground plan of surface rooms and a cavate room at LA 12588 in Cañada del Buey. This site is unusual in that the inner room has a large natural opening that gave onto two surface rooms.

Fig. 12.

Houses with cavate rooms. 
a. The rooms are coated with uniform, dense, black soot. This is not an irregular deposit such as would occur from small cooking fires of dry wood. Chemical analysis of the carbon deposit would probably show that it is from fires of resinous wood - fires unsuited to cooking or heating in a small enclosed room. I believe that the smoke stain was deliberately applied with a single fire.

b. The fire pit is near the entrance, and there is frequently a floor-level ventilator as well as a smoke vent high in the wall. These are practical features, but their arrangement suggests those of kivas. All the rooms are round or squarish with rounded corners. The ceilings are domed.

c. The lower face of the walls from the floor to a height of as much as $0.6 \mathrm{~m}$ was smoothly plastered with adobe. The rooms were used long enough so that this surface became dirty and had to be replastered from time to time. The dirty surfaces are scarred and sooty, but the soot is thin and bluish, not the dense black of that on the wall above.

d. Many cavate rooms show at least some traces of art work, all of which seems to be of a religious nature.*

A few cavate rooms in the survey area are small and isolated and have blackened interiors. Two, LA $12689 \mathrm{C}$ in Ancho Canyon and LA 12725 on Mesita del Potrillo (Fig. 11a), are almost perfectly preserved. These must have been quiet retreats for individuals - small caves for prayer. They are roughly circular in plan and not more than $1.5 \mathrm{~m}$ in diameter.

\section{K. Shrines}

Many shrines were located throughout the survey area. Most were in rather isolated locations, but some were near houses or villages. I have formed the impression, however, that the latter shrines were not contemporaneous with the occupation but were of a later period.

No shrines of the elaborate types described by Douglass (1917) were found; that is, no cairns or stone circles with radiating arms. Douglasis did show, in his Fig. 1, the symbol for a shrine marked No. 58 , but, other than including that number in a brief paragraph on rude stone circles, he gives no description of the site. Number 58 , from its position on Douglass' map, must have been near the survey area, but in the mountains, quite possibly at the eastern rim, overlooking the Rio Grande Valley.

Two carved humanoid faces that Douglass (ibid., p. 369 and Figs 1 and 7) termed the Shrines of (towi were not recorded on this survey, nor was any search made for them.

Three types of shrines were recorded in the present survey.

1. Rough Circles (Fig. 13). At the ends of long fingers of the mesas, one is likely to encounter roughly-made circles of large stones. The circles can be $2-5 \mathrm{~m}$ in diameter and, as a rule, they are alone, but occasionally two or three contiguous circles are found, as well as arcs of stone laid on the ground. There is nothing "pretty" or symmetrical about these places; they are simply spots where, in times past, men have gone to pray. The only thing they have in common is the type of location - they are all on points of mesas. Shrines of this sort are common throughout the northern Rio Grande country.

2. Square, Open Box Shrines (Fig. 14). Some of the first sites found during this survey were oneroom structures made of finely dressed blocks of tuff. Worman dug at least three of these (LA 4637, 4638, and 4658) and termed them storage houses,

\footnotetext{
*This business of trying to separate religious from nonreligious functions or artifacts of a primitive society can be tricky. I once had occasion to ride all day up Canyon del Muerto in a wagon with Tule Baia who was, in addition to being a fine gentleman, a prominent medicine man in the Canyon de Chelly area. Sometime during our long conversation that day, I made a distinction between religious and secular activities and Tule Baia's response was prompt and forceful. "No, everything we do is religious." One must consider that just about everything a primitive person makes or does, and probably every decision he makes, is accompanied by prayer or propitiatory action to forestall any counteraction by those evil spirits who constantly try to make life miserable for him. With that in mind, Tule Baia's statement can be accepted, but in the pre-Columbian Rio Grande the walls of dwellings were not generally painted or otherwise decorated; from the 14th century on, walls of kivas were frequently decorated.
} 


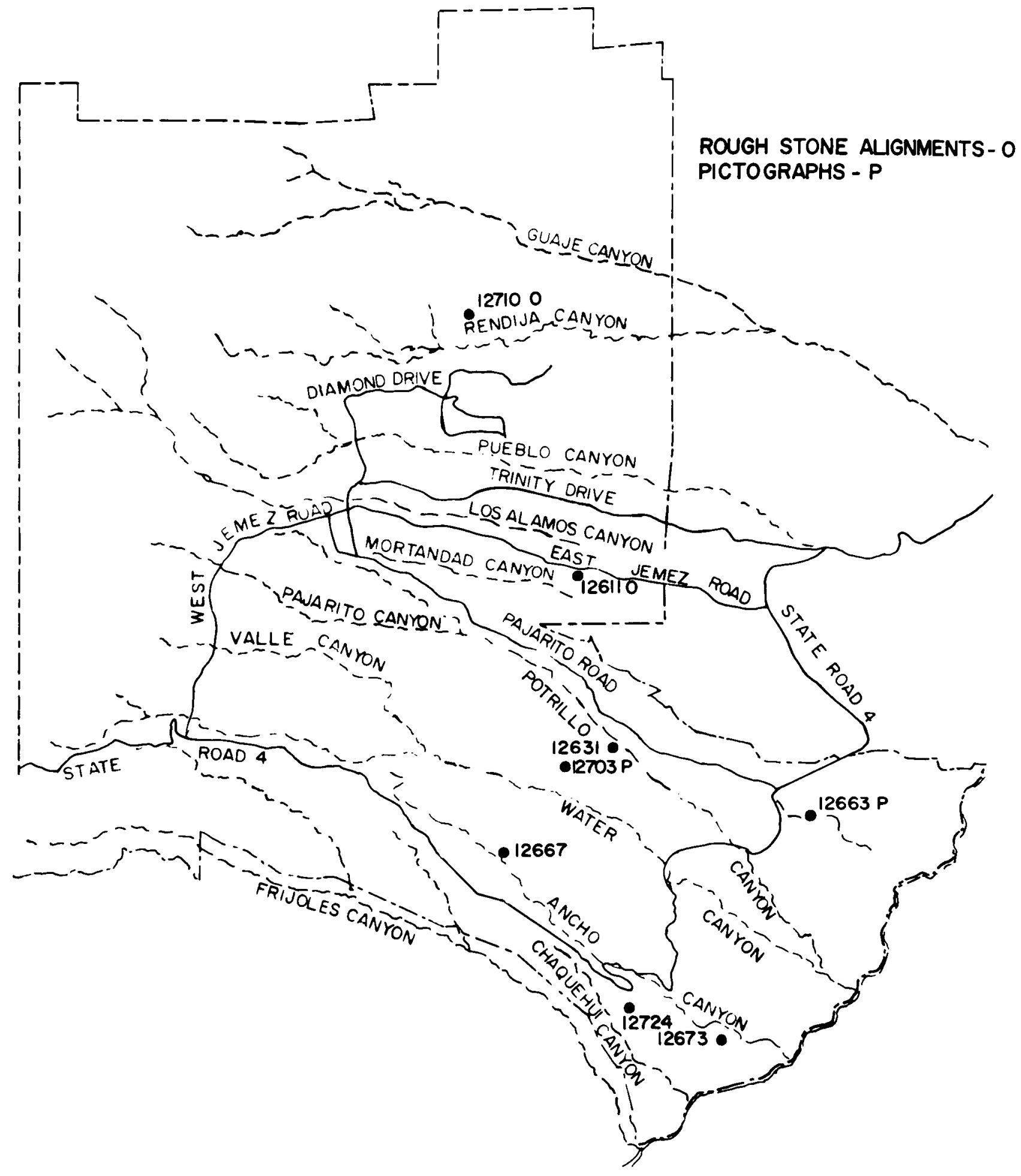

Fig. 13.

Shrines. 


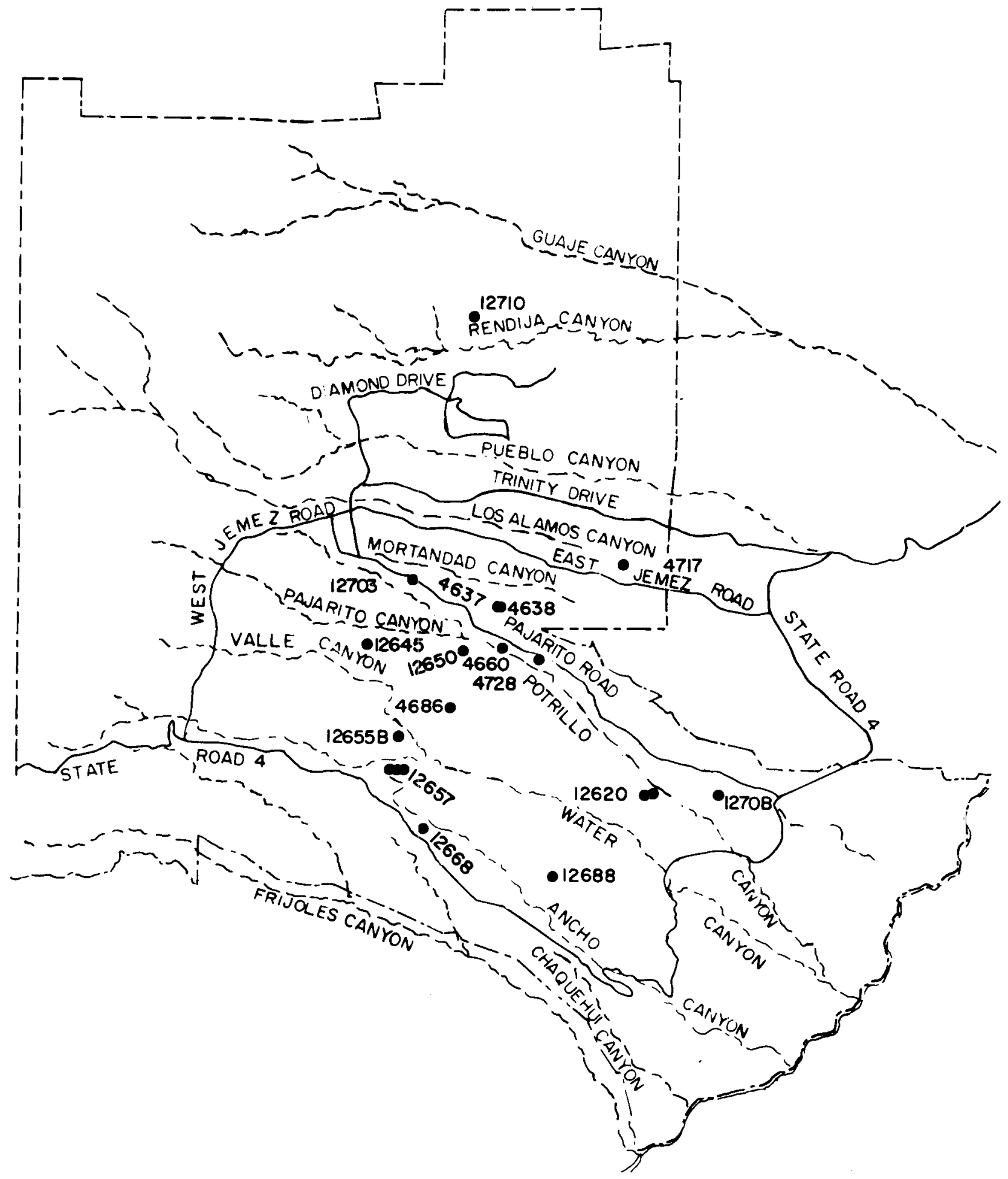

Fig. 14.

Square shrines. 
which was also my first interpretation of them. It was not until I saw two (LA 4680 and LA 4686) that had been dug and left open that I realized that they were something more than simple field storehouses.

These structures vary in size from 1 to $2 \mathrm{~m}$ on a side. The stone work of the walls is as fine as any on the Pajarito Plateau, but the quantity of stone at each site is only enough to build the walls three to five courses high. They were evidently never roofed, nor were there floors of either clay or stone. The floor of LA 13286 (see the Appendix) was $25 \mathrm{~cm}$ below the ground surface; at this site there was possibly an altar of clay in one corner. At none of these sites is there any entrance.

These small sites are to be found throughout the survey area, but they are most numerous at the higher elevations. A few are as much as a halfkilometer (quarter-mile) from the nearest habitation sites, and where the open box shrines are near farmsteads or villages the two seem to be of different periods.

These must have been places to which a man would go for purely private meditation and prayer, and probably in the 14th-15th centuries local custom decreed that it was proper to construct a fine, low masonry wall at such places. Finds of flaked stone or pottery at these sites are rare and generally seem not to be directly associated with the shrines.

3. Rock Art Shrines (see Fig. 13). The rock art of the pre-Columbian Pajaritans seems to have been inspired by religious thoughts or activities, perhaps exclusively so. Most of it is concentrated near ancient centers of population, particularly in and near kivas or ceremonial rooms.

During the survey, two pictograph sites were located in which the rock art is the primary feature and there were no dwellings nearby.

LA 12703. On the north side of Fence Canyon within Technical Area 36 (TA-36) is a panel of pictographs which includes eight Kokopellis (the hunchbacked flute player), several Awanyus (plumed serpents), a number of concentric circles and birds, and a spotted quadruped similar to those at LA 12609. There is also a set of triangles like those at LA 12663. There are no ruins in the immediate vicinity, and near the ruins on the mesa there is more good rock for art work, but no pictures. One must infer that this was a sacred area.
LA 12663. As Pajarito Creek passes through the White Rock community, its north bank is formed by a thick lava flow. There are two vents at the base of the flow from which drafts of air emerge. One of the vents (Fig. 15a) has been cleaned out in recent years, and one can enter it (stooped over) for almost $6 \mathrm{~m}$. Atmospheric pressure probably determines the direction and force of the flow, but, so far as I know, the phenomenon has not been studied at this place.

It is delightful to stand in front of the vent on a hot summer afternoon, and this is just the sort of thing to impress the primitive mind (as well as one not so primitive). Near the vents are many pictographs - nearly all geometric (Fig. 15b). It is not known whether there were ancient settlements on the lava flow. Construction at White Rock would have wiped them out, but no sites are shown on the Fulton map of the immediate area, nor are there nearby sites on the south side of Pajarito Creek.

\section{Rock Art}

As the survey began, no intensive search was made for rock art sites, but as the work went on I was a little surprised that there were not more of them. As mentioned before, all the rock art seems to be contemporaneous with the larger, later sites.

The nature of the tuff made easy work for the pictographic artist, and techniques used are more various than in most areas with pre-Columbian rock art. The most common method of creating a figure was by pecking either the outline or the whole figure. Outlines of some figures were drawn by rubbing grooves into the rock face or by abrading the entire surface. Sometimes both techniques, pecking and abrading, were used in a single figure (Fig. 16).

On the south cliff at Tshirege (LA 170) is one of the finest petroglyphs on the Pajarito Plateau - a pecked figure of Awanyu, the plumed serpent (Fig. 17). Mrs. Marjorie Lambert, formerly with the Museum of New Mexico, first saw this petroglyph in 1932 and says that at that time traces of red and green paint were visible on the figure's surface. This raises two questions - how common was it to paint the pecked and abraded figures, and did the recent Tewa venerate the old figures and repaint them? It seems unlikely that 15 th century paint would last into the 20th century on such an exposed, southfacing surface. To guess at an answer to the first question - it seems likely that many, if not all, of 


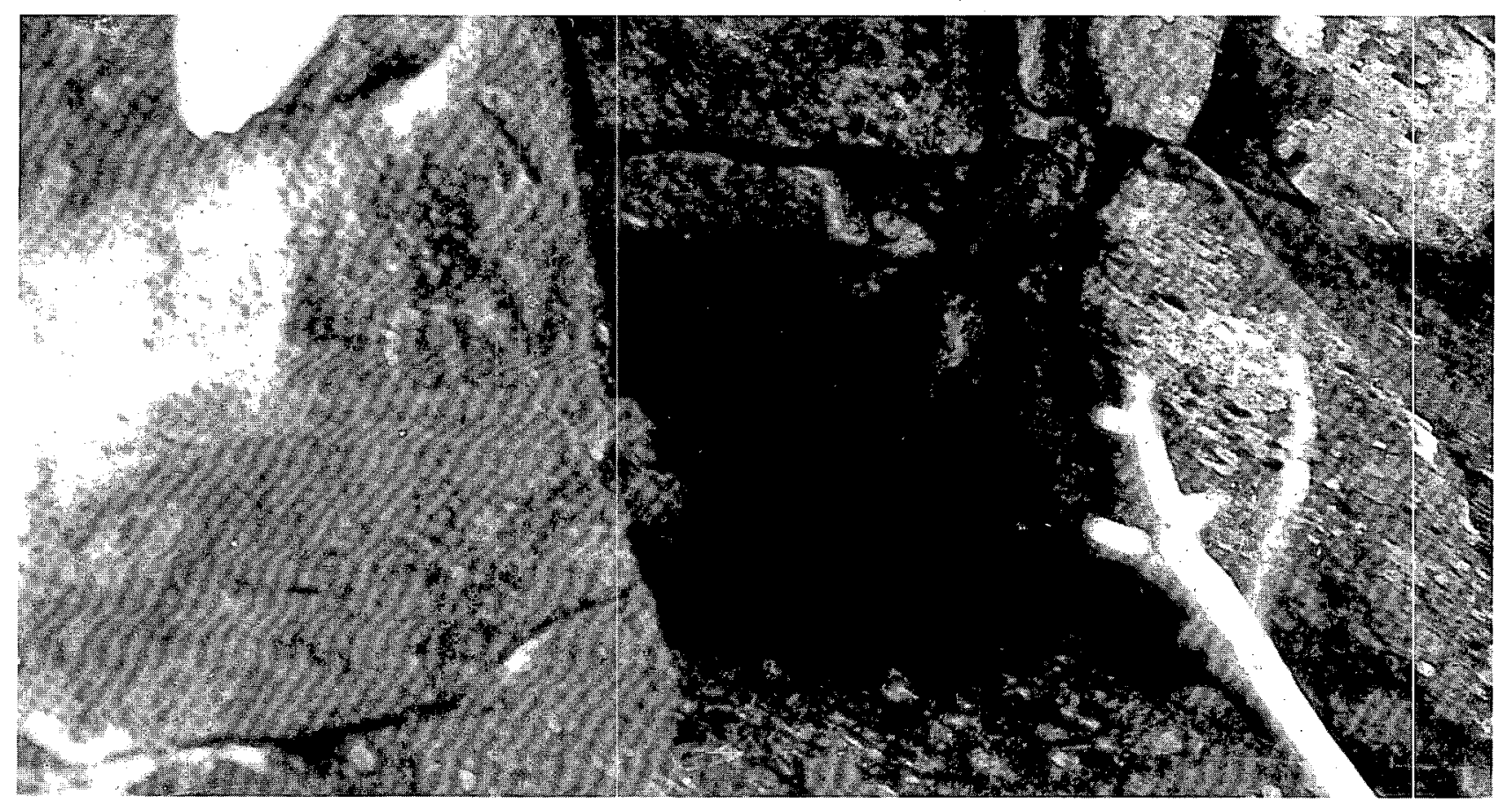

a. A vent through which air flows pass, at the base of the lava flow.

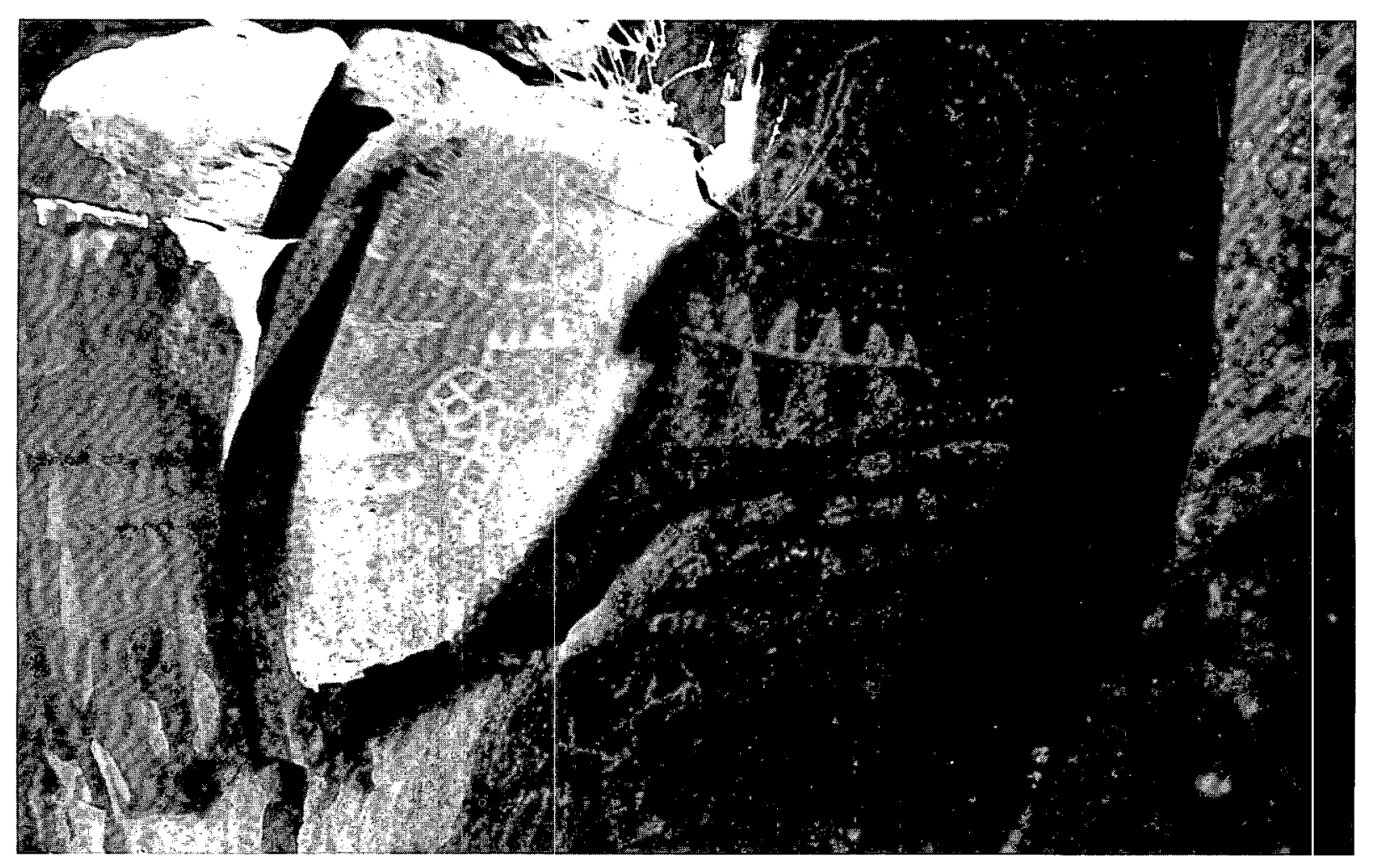

b. A panel of rock art beside the vent.

Fig. 15.

Site LA 12663. 


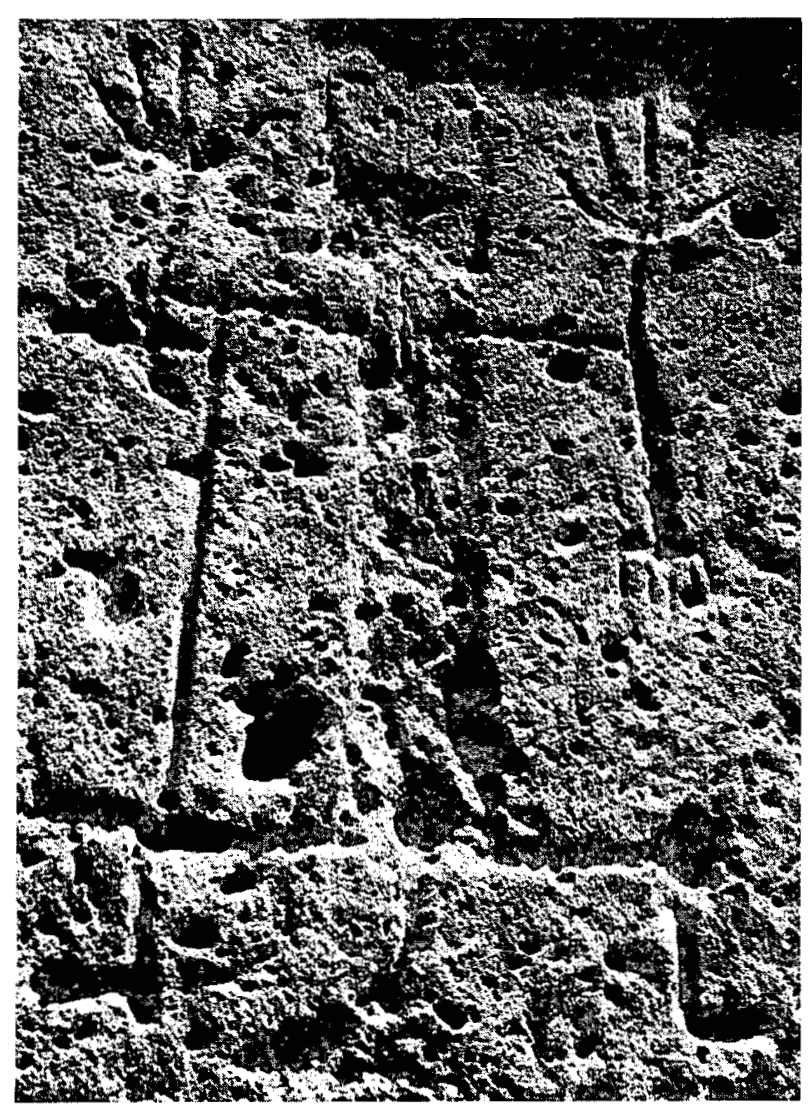

Fig. 16.

Anthropomorphic pictograph at LA 12712 in which arms, legs, and armbands were drawn by grooving the stone, and the body and part of the head were drawn by pecking.

the figures were painted at the time they were made. It also is probable that at least some notable figures like this one at Tshirege continued to serve as Tewa shrines until quite recently.

Anthropomorphic, zoomorphic, and geometric figures seem to have been made by all those who pecked away on the cliff faces, but no patterns or individual characteristics can be made out. There are, of course, some exceptions to that flat statement. At LA 12663, most of the figures are concentric circles, spirals, or solid triangles that rise from a common base line (Fig. 15b). At LA 12703, the other shrine with petroglyphs, the figures are largely zoomorphic and also include eight representations of Kokopelli. Strangely, although Kokopelli throughout the Southwest is generally ithyphallic, in the Fence Canyon petroglyphs he is most often shown without a penis.
The most interesting Pajaritan pictographs, as a class, are those associated with the small kivas or ceremonial rooms. The artists executed two styles of figures in these rooms, and I have termed them the Frijoles and Mortandad styles, using the names of the canyons in which these types predominate and in which the best examples are preserved.

1. Frijoles Style. In Frijoles Canyon, and occasionally north of it, a major part of the walls of small ceremonial cave rooms was covered with a coat of smooth mud plaster. The entire room was then smoked black. Into the black plaster surface, fine-lined figures were cut. When the work was first done, the figures must have appeared as brown lines against the black of the wall; today the lines have darkened so that often the figures are difficult to see. Chapman (1938) has described this style of rock art. It seems to be concentrated in Frijoles Canyon (I do not know whether any examples are to be found south of that canyon), and only two poorlypreserved fragments were seen during the LASL survey. Geometric patterns and lively realistic figures, $20-30 \mathrm{~cm}$ high are characteristic of this style, and life forms predominate. On one wall in Ruins Group M in Frijoles Canyon are two representations of an animal that seems to be a horse (see Fig. 5), which places this style in the historic period.

2. Mortandad Style. The almost perfectly preserved room at LA 12609 is the type site for the Mortandad style of kiva art. To create figures in this style, the artist first blackened the cave with a dense, black coat of sooty smoke (see Fig. 18). Then, with a hard point of some sort, quite possibly a sharpened stick, he cut through the soot to the light gray tuff beneath. The resultant figures are large, rather stiff and roughly done. The Kokopellis and the club swinger in Fig. 19 are the only figures in which any action is portrayed. This style was found from Ancho Canyon to Pueblo Canyon.

Few geometric figures were seen in any of the kivas; the style seems to run almost exclusively to life forms. Anthropomorphic figures, either masked men or gods, are common (see di Peso's letter below), but Kokopellis are seldom seen. The most common single figure is probably the Awanyu. Birds 


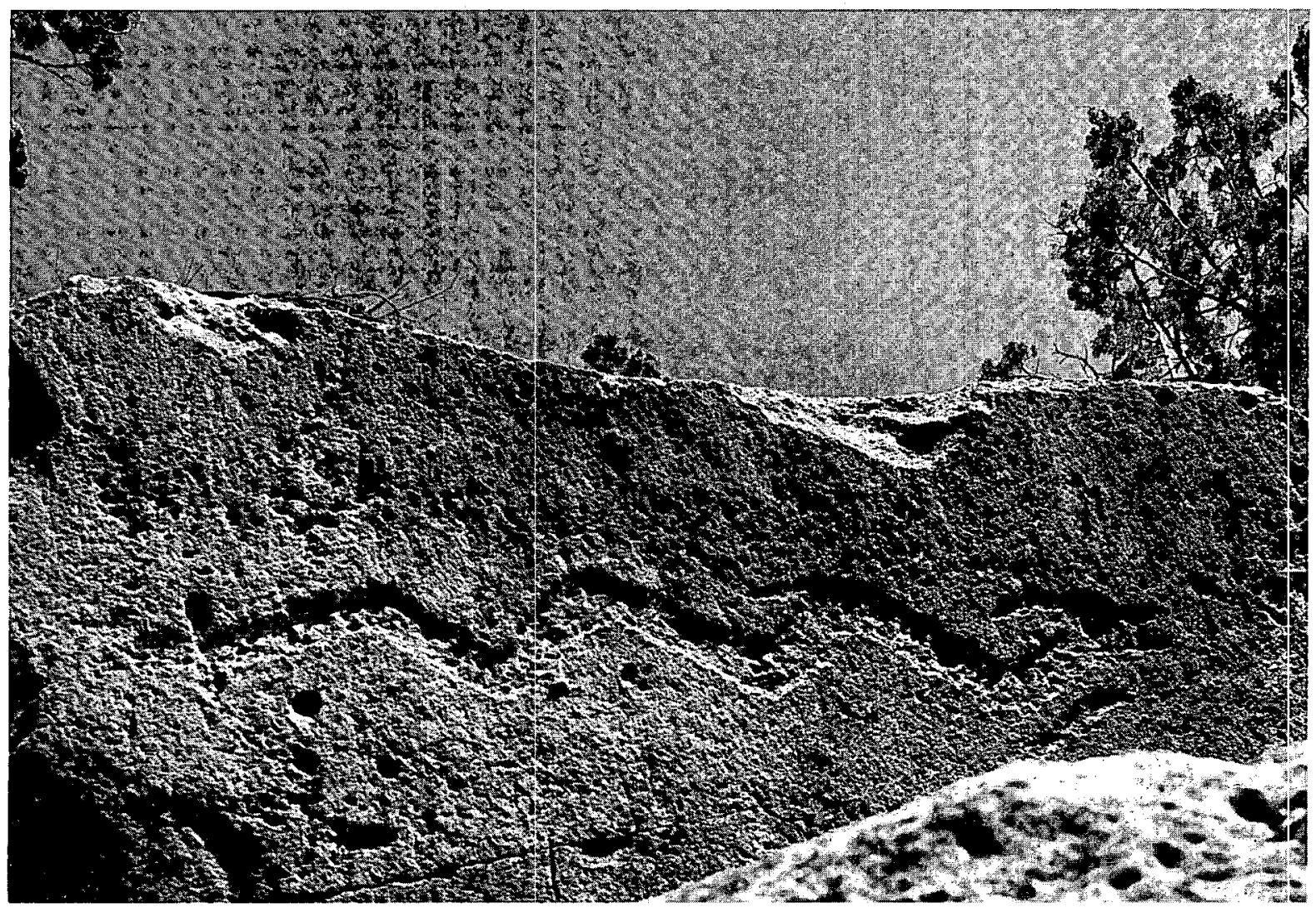

Fig. 17.

Awanyu, the Plumed Serpent, pecked on the cliff south of Tshirege ruin (LA 170). The figure is about $2.25 \mathrm{~m}$ long.

and quadrupeds are the other figures carved on the walls, and frequently they are shown in pairs in kissing position (Figs. 20 and 21).

Some of the figures seem to have a Mexican accent, so a set of photographs (Figs. 19-22) of the art work at the kiva at LA 12609 was sent to Charles di Peso of the Amerind Foundation, Dragoon, Arizona. His reply was:

"What a lot of wonderful decoration - exciting as hell and twice as much fun! Starting at the 'sunburst' kid, who occupies the area between the two entries - isn't he something! His sun body with the center cross is an iconographic form used by the Mesoamericans to represent Tonatiuh (Beyer 1965, pp. 147 and 169). In his left hand is a perfectly good 'horned serpent' and in his right, a T-shaped club. By the 14th15th century, when the kiva was in use, it is believed that Tonatiuh was submerged by the Huitzilopochtli complex (Nicholson in
Wauchope's Handbook of Middle American Indians, 10, pp. 424-426) in Mexico. If so, the Anasazi snake-in-hand portrait would resemble that of Huitzilopochtli, as depicted in the Codex Borbonicus 34 (Fig. 39).

The Kokopellis - hunched, ithyphallic flute player, and sundry sword swallowers, etc. the 'rainbow' Plumed Serpent, which was laid out as a design over the wall niche, suggests some affinity with Quetzalcoatl. Below it are the two long-tailed, spotted, kissing chanacters. They are a far cry from 'tigers,' but they are spotted and have long tails. Whether or not the one with ears or 'horns' is a male and the other a female is open to one's imagination. Further, is there a relationship between this pair and the Plumed Serpent with the bifurcated tail - it remains an interesting supposition. 


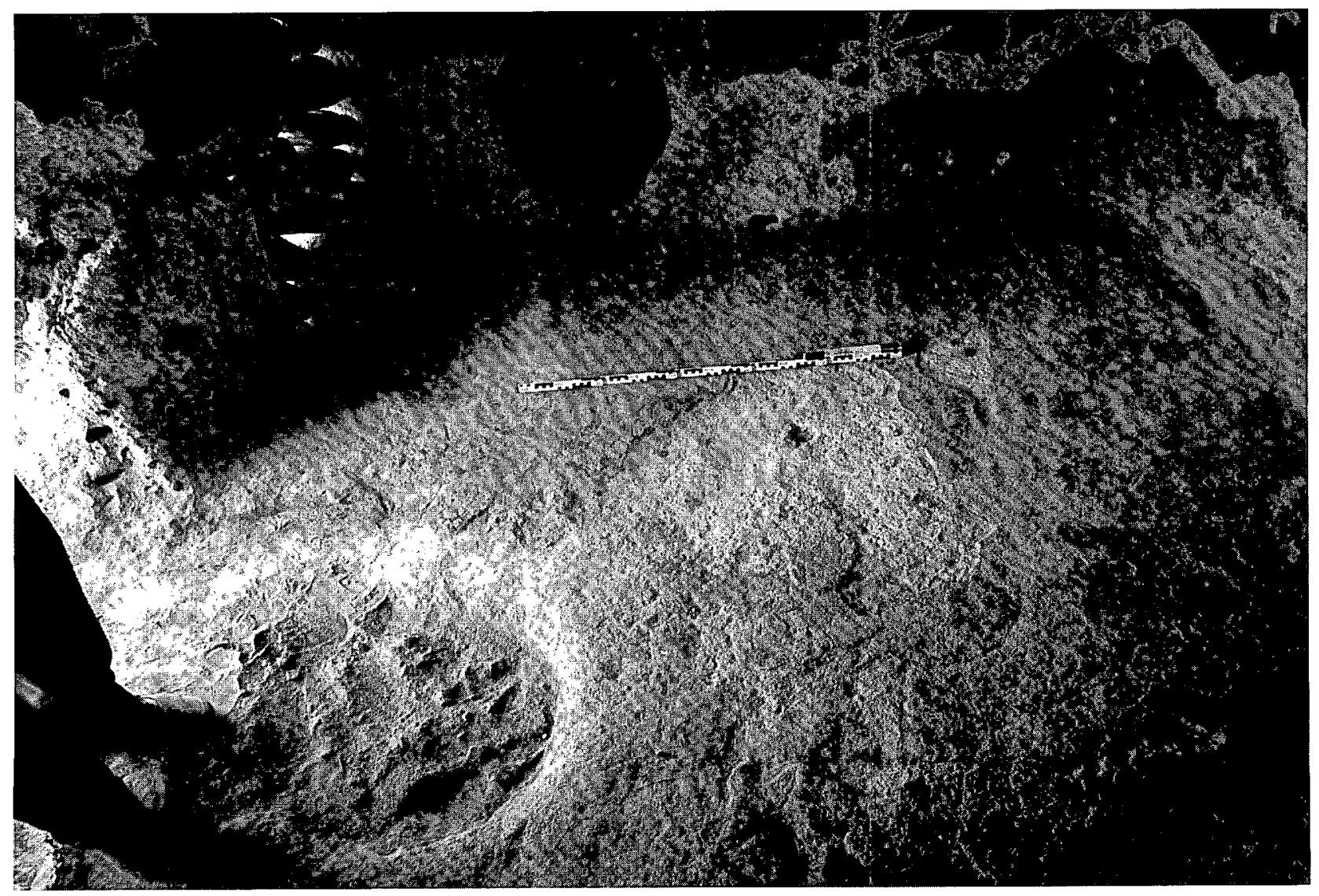

Fig. 18.

The well-preserved plaster floor at LA 12609 and, at the left, the firepit. Note the smooth, only slightly darkened surface of the plaster as opposed to the dense black of the walls in which the pictographs were carved. (Meter stick shown.)

The main character perched in the wall between the two niches seems to be carrying a shield in one hand and a club in the other. The two-horned helmet may be somehow related to the Western Pueblo and the horned gents from the West Coast of Jalisco, Mexico, which Peter Furst is so interested in (Sculpture of Ancient West Mexico, by Kan, Meighan, and Nicholson 1970, p. 70, Fig. 89).

Not much I can say about the kissing animals noted over the last niche and over the first niche where the horned helmet stands."

One must not get the impression that all the cave kivas from Ancho to Pueblo Canyon were decorated in this manner. From more than half the hundreds of cavate ceremonial rooms, the inner surface has exfoliated so that all trace of any former designs has disappeared. At other sites, the rooms were blackened but not decorated. Where the Mortandad style figures were cut into the walls, normally only one or two figures were made. We are fortunate that the best preserved kiva also contains the most figures.

\section{Game Pits}

The game pits of the Pajarito Plateau have been known since men began to search out ruins in the area. Hewett's 1904 map shows the location of several, as does Douglass' map of 1917. They are frequently referred to as deer traps. Some were certainly made as deer traps (Fig. 23), but others, just as positively, must have been used for capturing eagles (Fig. 24). The two types of pits were alike in 


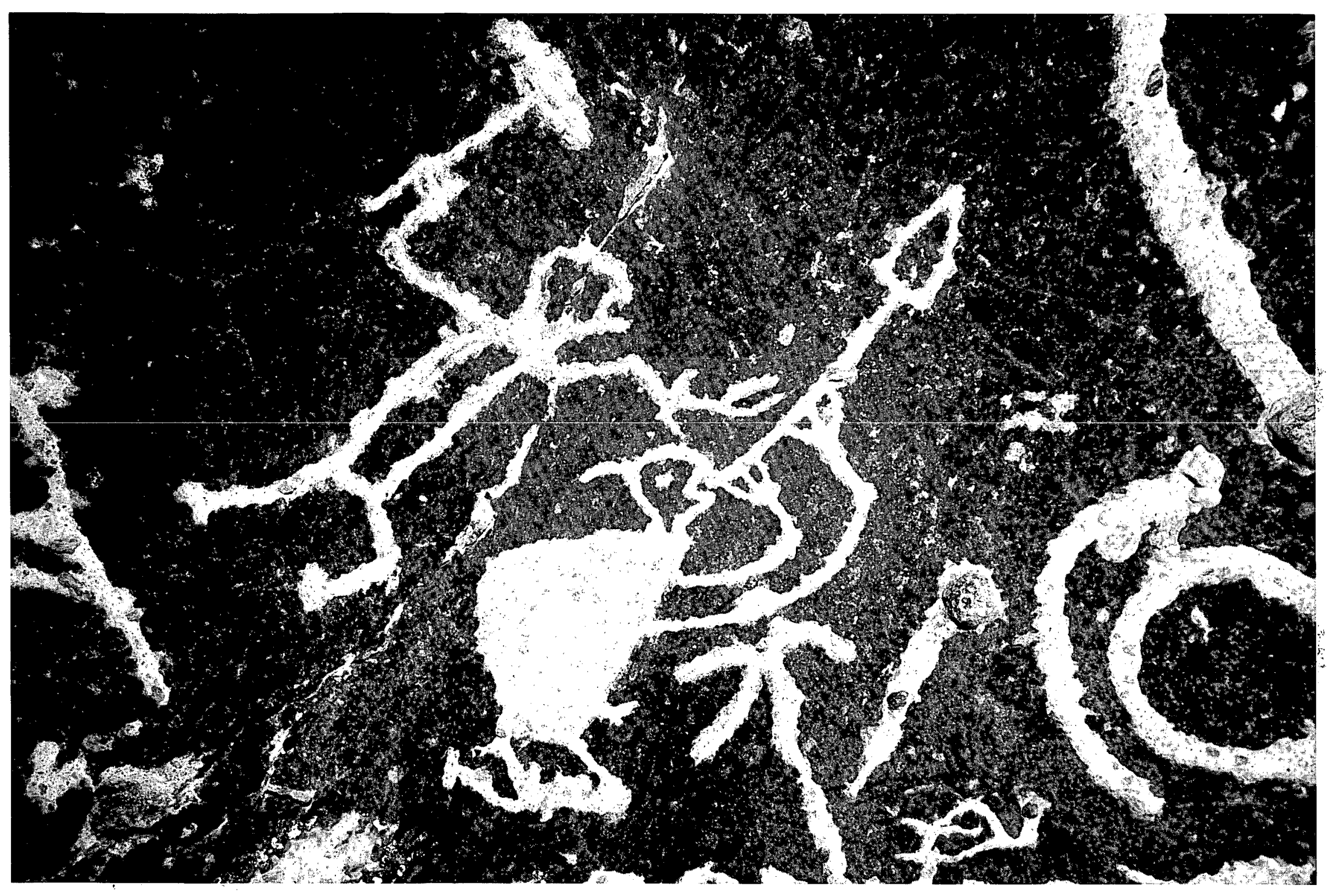

Fig. 19.

In an unusual, porhaps unique, representation of magic, Kokopelli is shoum suallouing an arroul It is not knoun whether the club swinger is aiming at the hunchback, but these are rare portrayals of action. "Sword" swallowing is a practice of a curing society at Zuñi (Stevenson, 1904, p. 444 et seq.). 


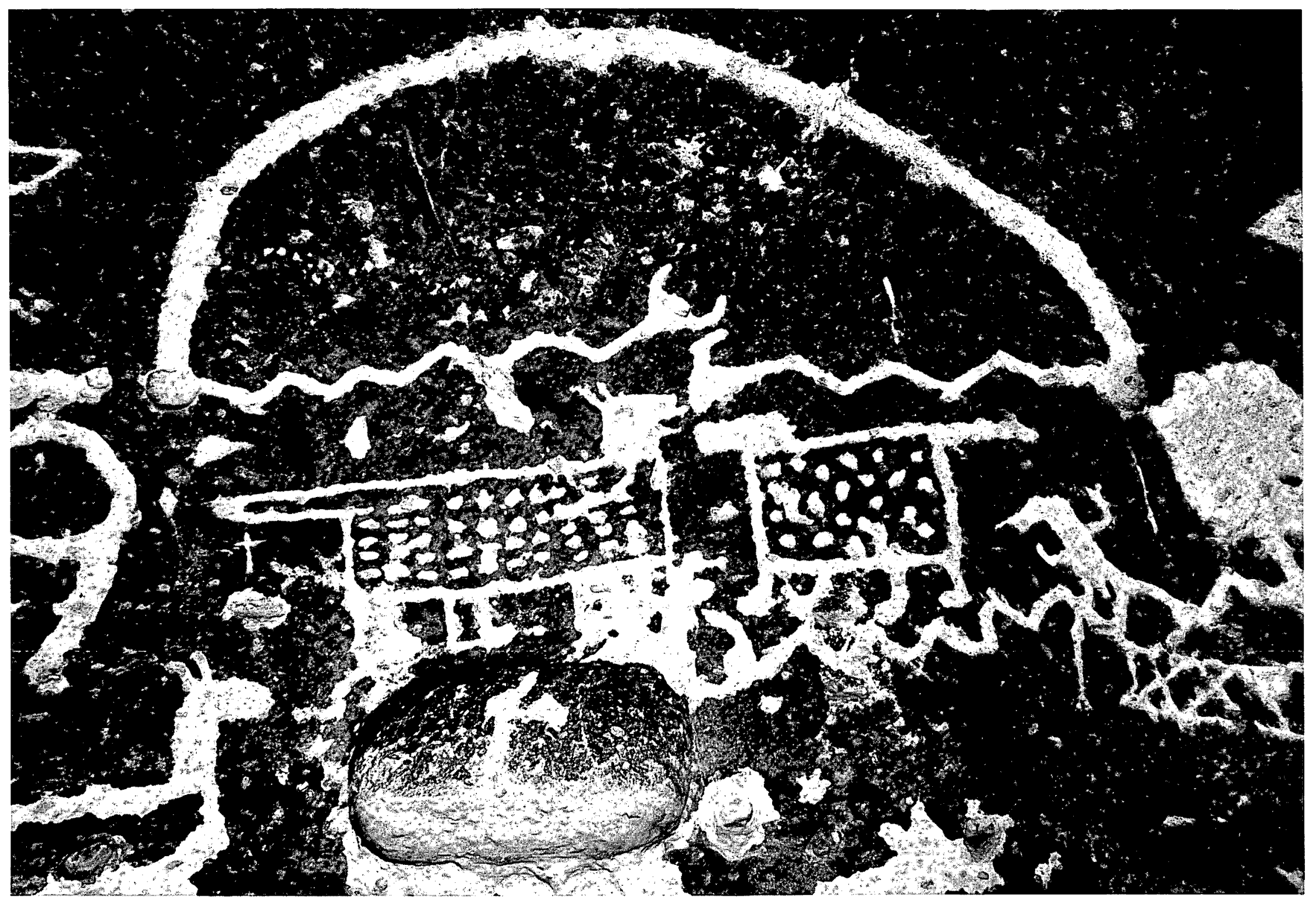

Fig. 20.

The Mortandad style of kiva art, showing the Rainbow Awanyu and two spotted quadrupeds that may be jaguars. 


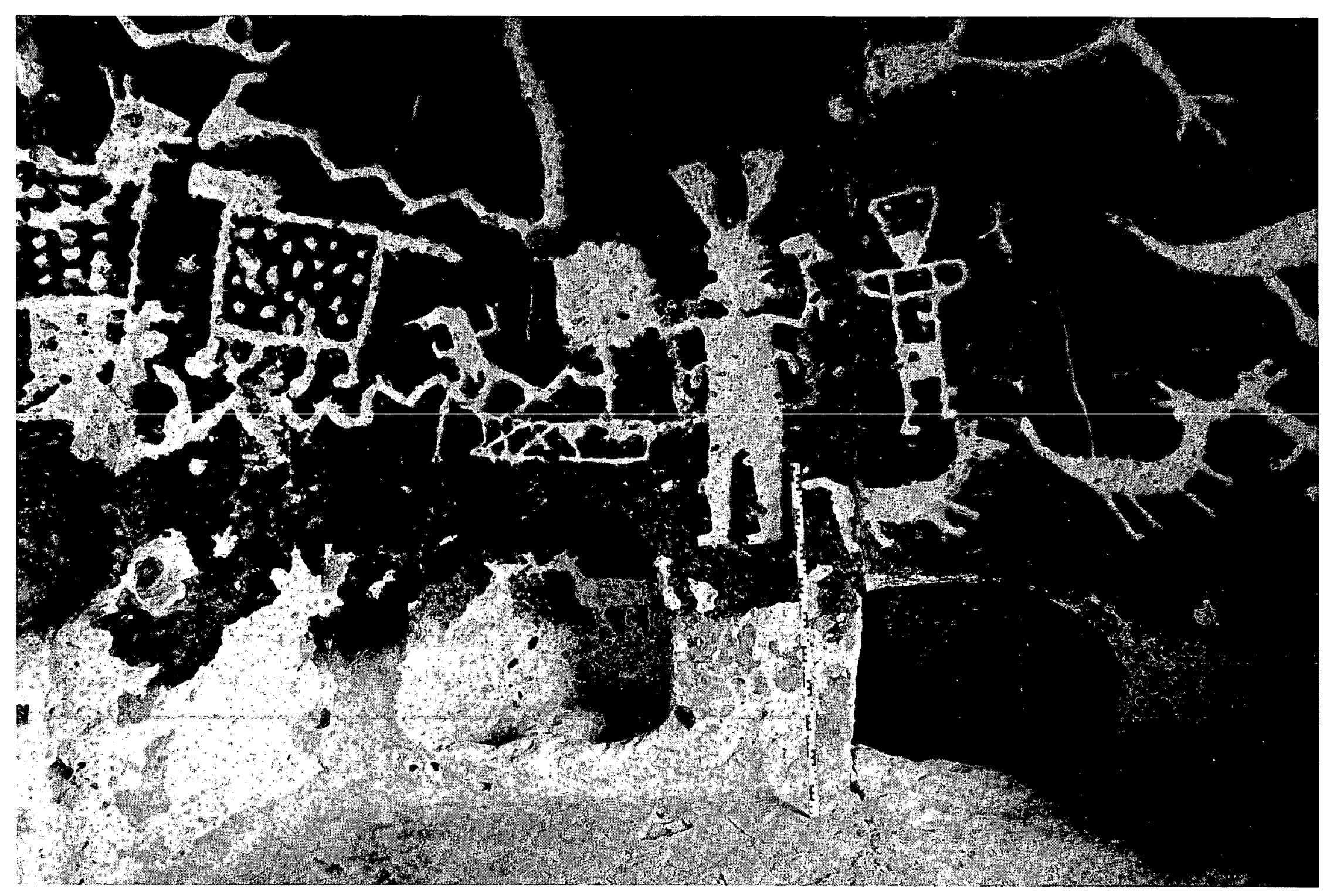

Fig. 21. 


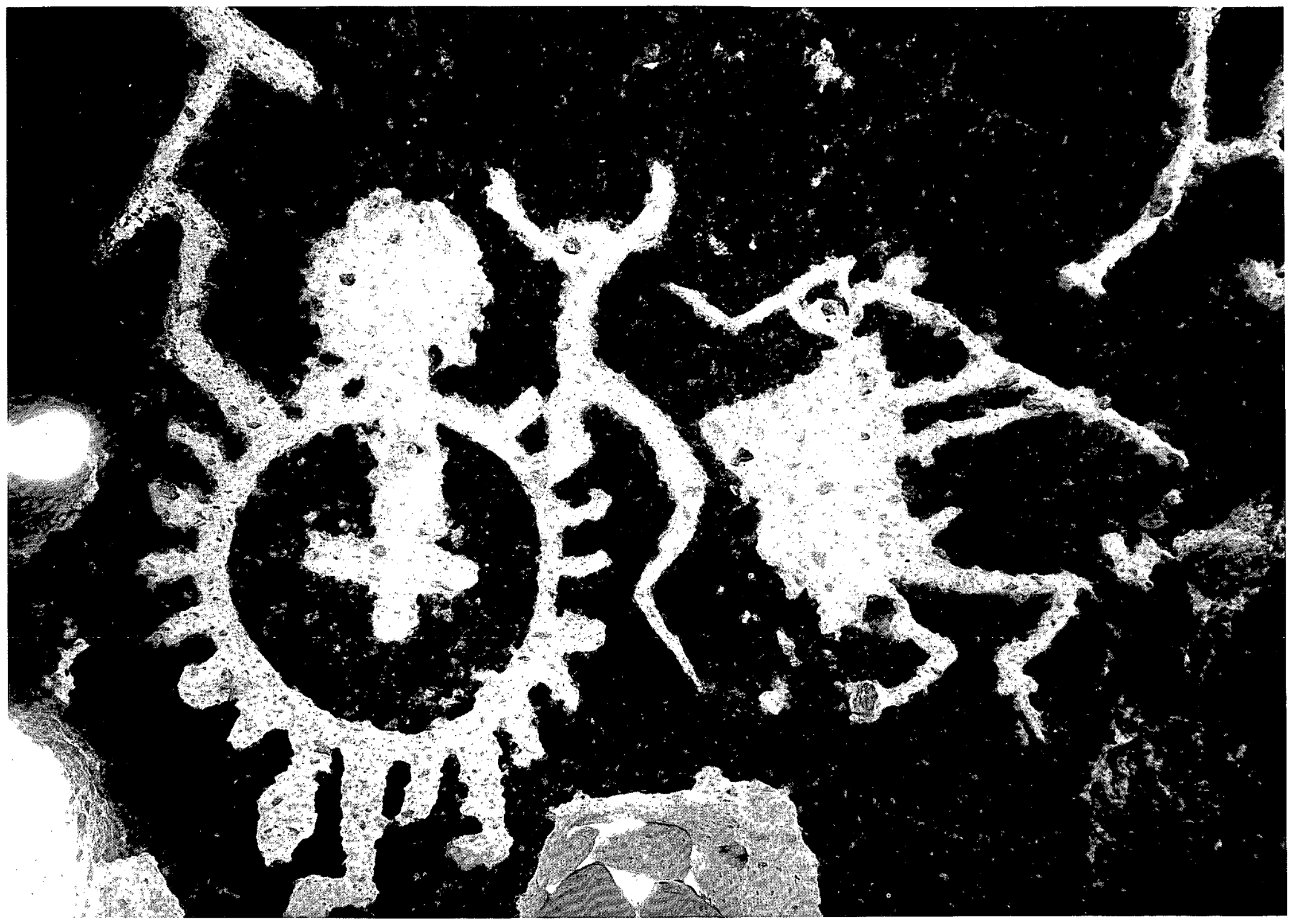

Fig. 22.

On the left is a possible representation of a Mesoamerican Sun god and, on the right, a Kokopelli. 


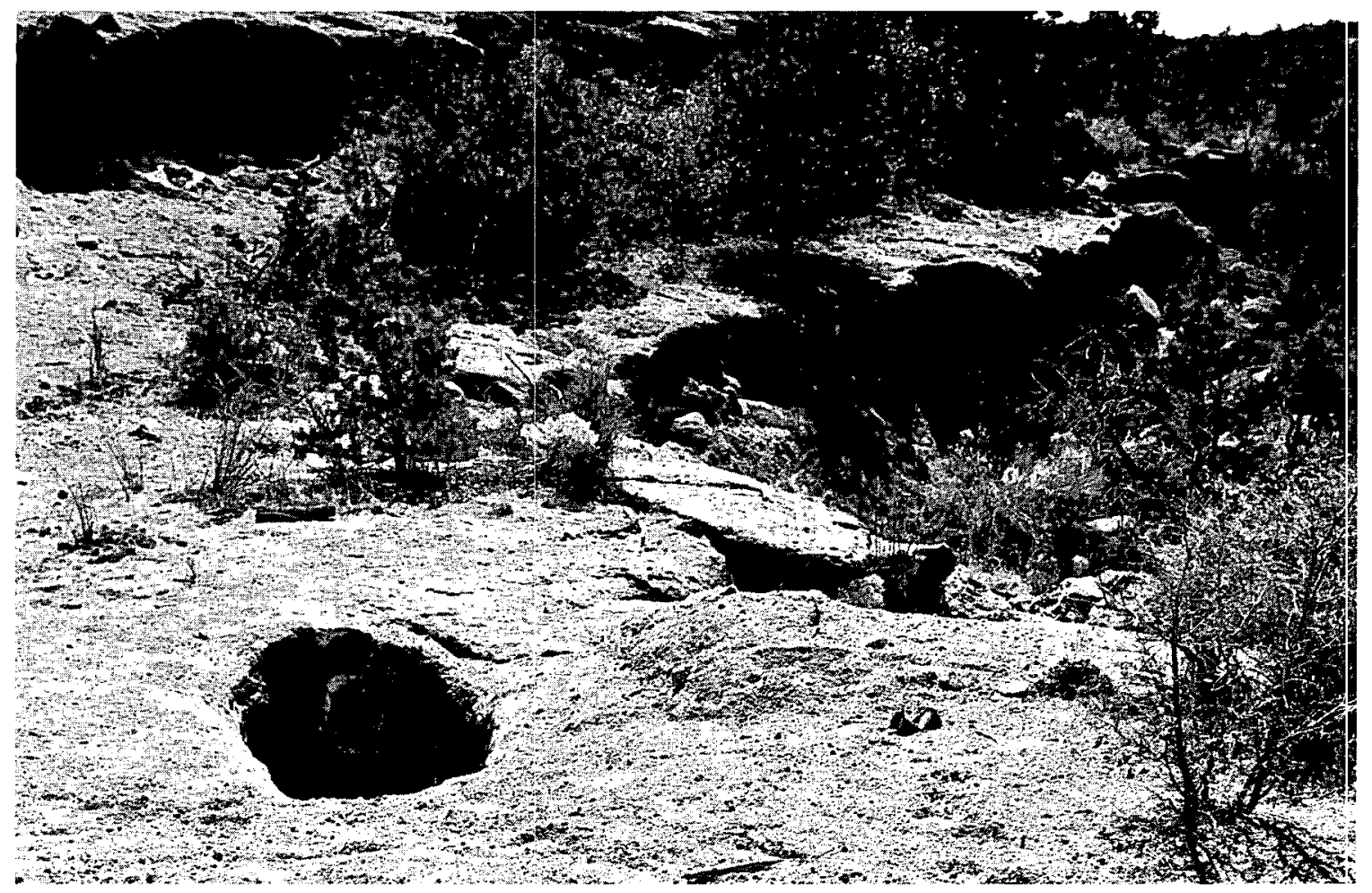

Fig. 23.

LA 12612. The deer trap at the rim of the mesa. Note the easy access to the pit from Mortandad Canyon at the right.

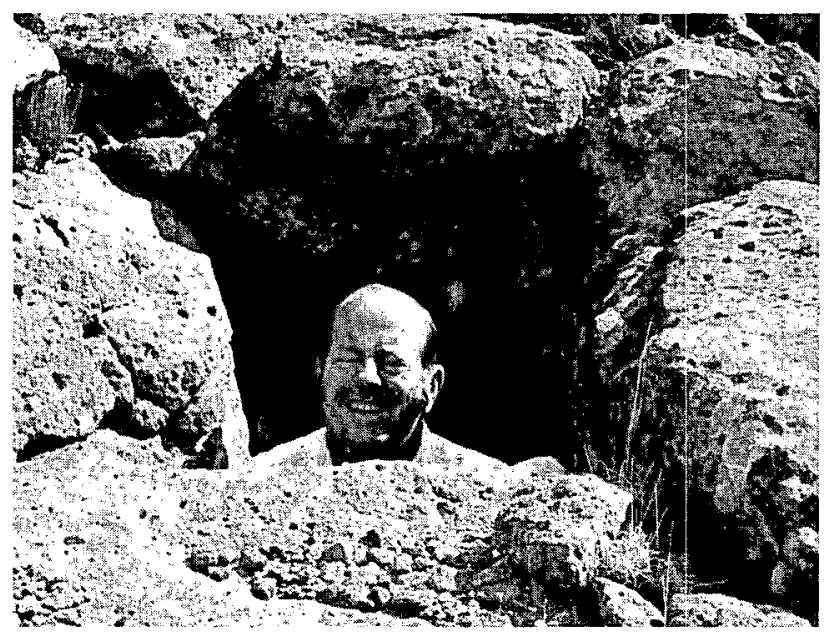

Fig. 24.

LA 12704, an eagle-trapping pit on the high mesita between Water and Fence Canyons. manner of construction and size; they differed only in the locations chosen for them. The pits were dug into tuff, at places where it had no soil covering. They were about $2 \mathrm{~m}$ long by about $1 \mathrm{~m}$ wide and were a little less than $2 \mathrm{~m}$ deep.

\section{Deer Pits}

Deer pits were dug on low saddles between canyons. They were probably hidden with a covering of light brush and given wing walls of juniper and piñon branches, so that a deer could be driven from a canyon up a slope to the saddle and forced to the pit where, hopefully, it would step on the cover, fall through, and break a leg or its neck.

Sometime during the late 1940s, I visited the game pit near Navawi ruin, and at that time there were vestiges of heavy brush wing walls on either side of the pit. 
The only game pit in the survey area which can safely be called a deer trap is that at LA 12612. It is located on a low saddle between two mesas, at the head of a rather gentle slope out of Mortandad Canyon. It could easily have made the apex of two brush wing walls and have been used to trap game driven from the canyon.

\section{Eagle Traps}

Scattered throughout the Pajarito Plateau are a few pits that could not possibly have been used for trapping deer. They are on the edges of high mesas or on very rugged points. With two men in the pit and a bait, like a rabbit, tied to the brush cover, the trap was set. The men might have to wait for a while, possibly two days or more, but, hopefully, an eagle would eventually spot the bait and swoop to capture it. It is said that once an eagle gets its talons into bait it is reluctant to let go, so the task of the men in the pit would first be to tie the bird's legs and then its powerful wings. So secured, it would be easy to carry home. Opposing sockets in the pit walls were pretty obviously meant to hold a beam, probably used for snubbing the heavy cord used to tie the eagle's legs (see Fig. 25).

Both deer and eagle traps were probably dug and used after the abandonment of the Pajarito Plateau as a site for villages. There would have been few deer nearby while Indians lived on the mesas. The

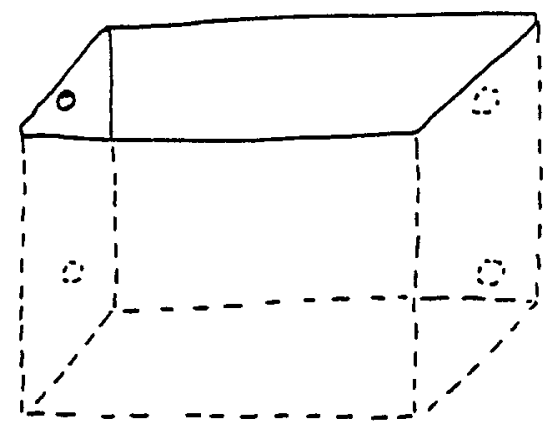

Fig. 25.

A schematic sketch of an eagle trapping pit. The upper sockets would hold a beam to support the roof, and the lower sockets would hold a snubbing post. remains of brush wing walls at Navawi indicate late nineteenth century and probably early twentieth century use, but there is no way of determining when the pits were dug. Clyde Aquero, of Cochiti, has told me that eagle traps of the sort described here were used at Cochiti until quite recent times. The modern bait was a lamb. Until the custom became illegal, most of the Rio Grande Pueblos had a captive eagle in a cage as a source of important feathers.

\section{N. Trails}

Trails worn into tuff surfaces of the mesas are prominent features on the Pajarito Plateau (Fig. 26), and they are found throughout the survey area. Most of the trails that can be seen today are short stretches where ancient paths crossed exposed rock surfaces. They are most frequently encountered on the mesa rims at points where the Pajaritans passed to and from the canyon bottoms.

The trails visible today are seldom more than 20 $30 \mathrm{~m}$ long. There is a series of trails on the long ridge above LA 12604, however, which extends for more than $150 \mathrm{~m}$. It was apparently part of the route from Tsankawi to Mesita de los Alamos. There is also a long section of trail exposed on the mesa south of Pajarito Canyon near LA 12635 and LA 12636. At this latter location, the pre-Columbian trail can sometimes be confused with wagon ruts of the old Buckman-Sawmill road that also passed down the mesita.

Where the trails dropped into the canyons, the Indians frequently pecked steps into the low cliff faces. Most commonly, the steps were irregularly placed and furnished a series of convenient footholds in crevices of the rock face or on a series of large boulders. Occasionally, sets of steps were made, as at LA 12609.

Rarely, flights of stairs were hammered into cliff faces where sloping rocks made them possible. The best preserved of these stairs was at the Guaje Site, LA 12700. Unfortunately, a rockfall during the winter of 1974-75 destroyed most of this feature of the ruin. The stairs were approximately $1.5 \mathrm{~m}$ wide and had fairly uniform risers of about $20 \mathrm{~cm}$ and treads of about $30 \mathrm{~cm}$. A second flight of stairs nearby was destroyed by an earlier rock fall. 


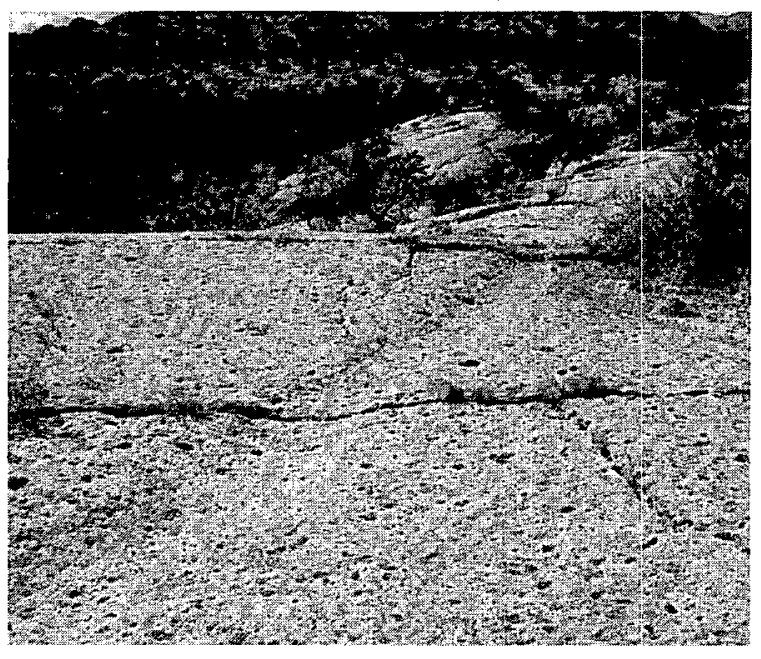

a. Trail near the east end of Mesita de los Alamos.

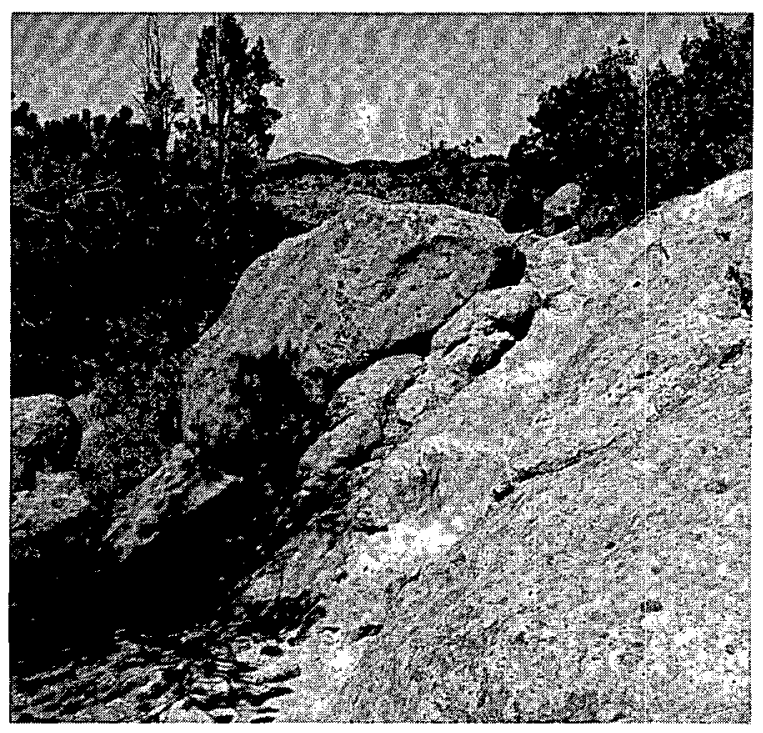

\section{b. Site LA 12609 in Mortandad Canyon.}

Fig. 26.

Ancient trails.

\section{O. Caves}

Although the tuff of the Pajarito Plateau can be cut or pecked easily to produce small artificial caves, the stone is not a cave-making formation. There are no caves as such and only a few small overhangs that can be termed rock shelters.
Only one rock shelter used by the Pajaritans was seen during the survey. It has a square floor, and the peak of the overhang is some 4-5 m high. Within the cave are roof beam holes for three small rooms, one petroglyph of a turkey track, and dozens of toolsharpening grooves. This is site LA 12589, near the rim on the north side of Jemez Canyon.

\section{P. Water-Collecting Device}

In Ancho Canyon, within TA-39, is a curved drystone wall (Fig. 27) at the foot of the cliff below a runoff channel; this is part of site LA 12689. The basin created by the wall is filled with silt and gravel carried by water running down the cliff face, and, without excavation, there is no way of determining the wall's function. A reasonable guess is that it was built to protect one or two ceramic jars placed to catch water running from the cliff during rain storms.

\section{Q. Classification of Sites Surveyed}

The following list of sites on the Pajarito Flateau is classified according to the types outlined in this section. The most numerous sites are those with one or two rows of rooms at which the predominant pottery type is Santa Fe Black on White. The later, larger sites are fewer in number, and this fact leads one to believe that the population of the Flateau probably remained fairly constant from the 13th

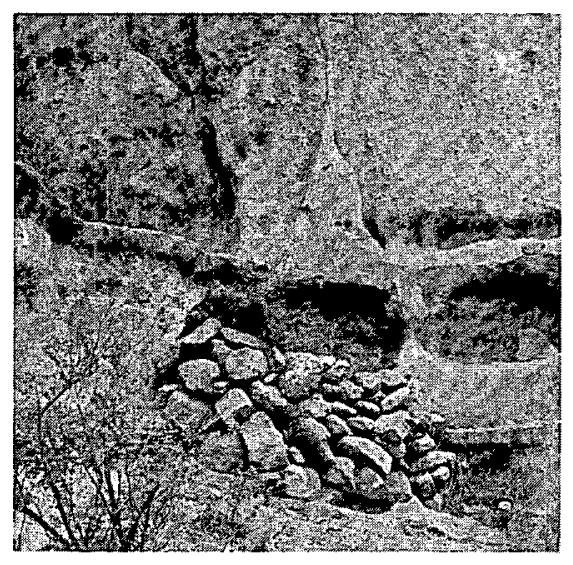

Fig. 27.

LA 12689. A drystone wall which might have served to protect water jars placed at the bottom of a runoff. 
century until the general abandonment of the area in the 16th century. Some sites are listed under two headings, and a few are shown in three classifications when the physical evidences warrant so doing. In the classification "sites with kivas," the numbers with question marks represent locations at which there is some indication, but not a clear one, of a true subterranean or semisubterranean kiva.

Three or More Rows of Rooms Santa Fe and/or Wiyo Black on White

$\begin{array}{rr}344 & 12600 \\ 345 & 12626 \\ 347 & 12617 \\ 4625 & 12618 \\ 4627 & 12619 \\ 4628 & 12647 \\ 4629 & 12665 \\ 4632 & 12669 \\ 4656 & 12682 \\ 4684 & 12685 \\ 4704 & 12688 \\ 12593 & 12716\end{array}$

\section{Sites with Kivas}

$\begin{array}{cccl}29 & 394 & 4681 & 12625 \\ 32 ? & 4601 ? & 4693 ? & 12626 ? \\ 169 & 4607 & 4697 & 12629 \\ 170 & 4610 & 4704 & 12630 ? \\ 344 ? & 4639 & 4708 & 12636 \\ 345 ? & 4612 ? & 4718 & 12655 \\ 346 ? & 4616 ? & 4721 & 12657 ? \\ 347 ? & 4617 ? & 6787 ? & 12664 \\ 350 & 4692 ? & 12598 & 12684 ? \\ 351 & 4654 ? & 12609 & 12686 ? \\ 352 ? & 4655 ? & 12612 & 12688 ? \\ 353 ? & 4659 & 12616 ? & 12694 ? \\ 355 & 4665 & 12646 ? & 12718\end{array}$

\section{One or Two Rows of Rooms} Santa Fe Black on White

$\begin{array}{lrrr}343 & 4655 & 4711 & 12644 \\ 346 & 4657 & 4712 & 12646 \\ 348 & 4660 & 4713 & 12648 \\ 349 & 4661 & 4714 & 12649 \\ 353 & 4662 & 4715 & 12651 \\ 354 & 4663 & 4726 & 12652 \\ 4602 & 4664 & 4717 & 12653 \\ 4603 & 4666 & 4722 & 12656 \\ 4604 & 4668 & 4723 & 12657 \\ 4605 & 4669 & 4724 & 12659 \\ 4606 & 4670 & 4725 & 12660 \\ 4608 & 4671 & 4716 & 12661 \\ 4609 & 4672 & 4727 & 12662 \\ 4611 & 4673 & 4728 & 12667 \\ 4613 & 4674 & 4729 & 12668 \\ 4614 & 4675 & 6786 & 12670 \\ 4615 & 4676 & 6787 & 12672 \\ 4618 & 4677 & 6788 & 12674 \\ 4620 & 4678 & 6791 & 12675 \\ 4621 & 4679 & 6792 & 12676 \\ 4624 & 4681 & 12587 & 12677 \\ 4626 & 4683 & 12590 & 12678 \\ 4630 & 4685 & 12591 & 12680 \\ 4631 & 4687 & 12592 & 12681 \\ 4633 & 4688 & 12594 & 12683 \\ 4634 & 4689 & 12595 & 12684 \\ 4635 & 4690 & 12596 & 12687 \\ 4636 & 4691 & 12597 & 12688 \\ 4637 & 4692 & 12598 & 12691 \\ 4638 & 4694 & 12599 & 12692 \\ 4639 & 4695 & 12601 & 12695 \\ 4640 & 4696 & 12603 & 12697 \\ 4641 & 4697 & 12607 & 12699 \\ 4642 & 4698 & 12608 & 12700 \\ 4643 & 4699 & 12611 & 12705 \\ 4644 & 4700 & 12613 & 12706 \\ 4645 & 4701 & 12614 & 12710 \\ 4646 & 4702 & 12615 & 12713 \\ 4647 & 4703 & 12628 & 12717 \\ 4648 & 4705 & 12632 & 12719 \\ 4649 & 4706 & 12634 & 12720 \\ 4650 & 4707 & 12637 & 12721 \\ 4651 & 4709 & 12641 & 12722 \\ 4652 & 4710 & 12642 & 12723 \\ 4653 & & 12643 & \\ & & & \end{array}$


Sites with Cavate Rooms and Rock Art

$\begin{array}{rrrr}170 & 12604 & 12689 & 12707 \\ 355 & 12609 & 12700 & 12725 \\ 12588 & 12612 & 12702 & 12743\end{array}$

\section{Cave Site}

12589

Historic Period Rock Alignment

12602

Water Collection Device

12689

Rock Art but no Structures

12663

12703

\section{Agricultural Sites}

$\begin{array}{rr}354 & 12698 \\ 12605 & 12701\end{array}$

Parallel Rows of Rooms with Extension to Make an L- or U-Shaped Pueblo

$\begin{array}{rrrr}338 & 4659 & 12623 & 12657 \\ 352 & 4718 & 12624 & 12664 \\ 394 & 4719 & 12625 & 12671 \\ 4601 & 12714 & 12627 & 12686 \\ 4612 & 12715 & 12630 & 12690 \\ 4616 & 12606 & 12633 & 12694 \\ 4617 & 12610 & 12635 & 12696 \\ 4619 & 12616 & 12636 & 12700 \\ 4622 & 12620 & 12638 & 12709 \\ 4623 & 12621 & 12639 & 12714 \\ 4654 & 12622 & 12640 & 12715\end{array}$

\section{Plaza Sites}

29
32
350
351
355
4607
4610

4639
4665
4681
4694
4708
4721
12609

12625

12629

12636

12655

12664

12700

12718

\section{Large Sites}

169 Otowi

170 Tshirege

\section{Box Shrines}

$\begin{array}{rr}4658 & 12654 \\ 4680 & 12658 \\ 4699 & 12679 \\ 12645 & 12708 \\ 12650 & 13286\end{array}$

\section{Game Pits}
12612
12631
12658
12693
12704

Large Boulder and Cairn Shrines

$\begin{array}{ll}12601 & 12663 \\ 12631 & 12673 \\ 12642 ? & 12710 \\ 12650 & 12724\end{array}$




\section{AGRICULTURE ON THE PAJARITO PLATEAU}

The Pajaritans were agriculturalists. Many corn cobs have been recovered from sites over the $\mathrm{Pa}$ jarito Plateau; desiccated cobs from cavate rooms and charred cobs from open sites give ample evidence for the principal crop - maize. Excavations have also yielded cucurbit seeds and shells in some abundance. A rather spectacular find of a pottery bowl filled with cleaned cotton a few years ago (The Atom, November 1964, Harlow 1965) suggests that if cotton was not grown on the plateau, which it probably was not, it was cultivated nearby at lower elevations. No beans have been reported from the plateau, but there is no reason to doubt that the frijol, the third member of the triad of principal native American cultigens (maize, squash/pumpkins and beans) was grown here. One other domesticated plant is known from the area; tobacco has been identified from excavations at Frijoles Canyon (Hendron 1946).

To judge by the distribution of the earlier sites on the Plateau, those at which Santa Fe Black on White is the dominant pottery type, the entire area suitable for farming was in use. At the upper reaches of the inhabited zone, all farming must have been done on the mesa tops. The canyons there are too narrow, steep, and cold to permit crop growing. Only at lower elevations, where the canyons are shallow and wide and there is ample alluvial soil are there indications of primitive farming along the stream courses.

A picture of the Pajarito Plateau in the 14th century would probably show lines of widely dispersed houses, of 4-20 rooms each, strung along the crest of each mesita. The houses would have been surrounded by fields extending across the mesitas from a line where the soil became deep enough for farming along one rim to a similar line on the other rim. The low forest cover that is the dominant feature of the Pajarito Plateau landscape today would not be in the picture. It would take only a few years for the Indians to strip the mesitas of their trees - the need for timbers for construction and wood for fires, added to land-clearing for fields would have quickly destroyed whatever cover the Plateau supported. However, it seems safe to assume that the prePajaritan forest was essentially the same as that which now covers the plateau.
The soils of the mesitas are thin. Made up of decomposed tuff, they lie on tuff beds and are from zero to less than $1.5 \mathrm{~m}$ deep. At site LA 4630, the soil was only $0.30-0.35 \mathrm{~m}$ deep, and at LA 4722 it was 0.9 $\mathrm{m}$ deep. Primitive farming methods are hard on any soil and would be particularly so on that of the $\mathrm{Pa}$ jarito Plateau.

The usual primitive American Indian method of harvesting was to pull the entire plant, no matter what the crop, and take it home. At the house or in some nearby sheltered spot, a hard-packed clay floor served as a platform on which the harvest (ears of corn, cut-up squash, or beans) was spread to dry before being stored for the winter. All vines, leaves, and stalks were then piled near the house to serve as tinder.

With such a harvest system, and with no fertilizer applied to the fields, plant nutrients in the soil would be quickly exhausted. The evidence of site distribution indicates that at about the time Wiyo Black on White came into style the upper elevations of the mesas were largely abandoned and the population was concentrated below $2000 \mathrm{~m}(6700 \mathrm{ft})$. Villages remained on the mesa tops where undoubtedly the soil was no better than at higher elevations, but from there on to the east there were broad canyon bottoms and gentle talus slopes that could be put under cultivation.

It is in this part of the plateau that one finds traces of check dams across drainage channels (both on the mesas and in the canyons). Where there are basalt exposures, as at LA 354 and LA 12698, the heat-retaining properties of the stone were utilized and small, irregular terraces were constructed. The check dams and terracing seem to belong to the later period of occupation of the Pajarito Plateau; that is, from Wiyo Black on White times into the glaze paint pottery period.

The most extensive agricultural plot seen during the survey was not on the Plateau, but on a terrace of the Rio Grande in White Rock Canyon, the Pajarito Springs site (LA 12701). Garden plots, terraces, and a few one-room field houses extend for approximately $1 \mathrm{~km}$ on the sand and gravel terrace. A stone-lined ditch, much of it still intact, took water from Pajarito Creek to the vicinity of the fields, and smaller stone-lined ditches distributed the water to the crops. Rory Gauthier cleared a short section of one of the ditches in 1974. It was nearly $2 \mathrm{~m}$ wide and about $40 \mathrm{~cm}$ deep; the bottom of the ditch was 
flat and also floored with slabs. There is a possible remnant of a diversion dam across Pajarito Creek which could have thrown water into a series of ditches to water the terrace.

\section{Erosion}

Frequently the question arises as to how much erosion the surface of the mesitas has suffered since it was occupied by the Indians. I believe that the answer must be, "Negligible."

In some places, there has been serious channel cutting, and it still goes on. The mesa tops and drainages between Pajarito and Fence Canyons and just west of State Highway 4 are extensively cut by erosion, and I can see no cause for it. A second area of extensive erosion is on the lower end of Frijoles Mesa (within TA-33), where it apparently was started by movements of heavy tracked vehicles during World War II. Elsewhere on the mesas, channel cutting has been minor, and nearly everywhere erosion scars are now being covered by new growth.

A second type of erosion, frequently termed "sheet erosion," is a general lowering of the surface because of runoff. There is no evidence for any appreciable amount of this type of erosion, either. The end stones of 14th-15th century check dams across drainage channels are set into the sides of the channels in the same positions in which one would place them today to anchor a similar structure. In most cases the centers of the dams have been washed away, but the ends remain in place.

At both LA 4630 and LA 4722, the floors, or apparent floor levels, of rooms were just below the present ground level - just below the sod. Midden deposits built up adjacent to the houses feathered out to a level just below the sod line. Similarly, the intact rim of the small storage pit on the west side of LA 4630 lay just under the modern sod. All these facts add up to strong evidence that there has been no significant change in the ground level of the plateau since the pre-Columbian occupation.

\section{SOME IMPORTANT AND INTERESTING RUINS}

A few ruins, and groups of ruins on LASL lands deserve more than ordinary protection. Three ruin groups have been nominated for the National
Register of Historic Places. They are LA 32 and LA 169 (Little Otowi and Otowi), LA 170 (Tshirege), and LA 12609 and LA 12612 (the cavate rooms, deer trap, and plaza site on the north side of Mortandad Canyon). All these are large ruins groups with a high potential for yielding important data for Rio Grande archaeology. When they are placed on the Fiegister, their importance will be recognized and they will be protected from damage by any activity in which Federal funds are involved.

\section{LA 32 and LA 169}

Little Otowi (LA 32) consists of two large house blocks with a plaza between. The site is so covered by a dense growth of sage brush that it is difficult to see features. The mounds are high, and it seems likely that the buildings were two stories high.

A large part of the Otowi ruin (LA 169) has been excavated but, as one of the largest sites on the plateau, it probably remains one of the most important.

\section{LA 170}

Tshirege is the largest village site on the Pajarito; it is estimated to contain about 600 rooms within the house blocks on the mesa, and there are many cavate rooms in the low cliffs on the south sicle of the mesa. There are many striking examples of preColumbian rock art on the cliff, including the great figure of Awanyu shown in Fig. 17.

\section{LA 12609 and LA 12612}

These two numbers have been given to the assemblage of cavate rooms, plaza site, trails, and deer trap strung along the north side of Mortandad Canyon. The cave kiva previously described and illustrated in Figs. 18-22 is a unit of this group. Two survey numbers have been allotted to the sites, because the deer trap (Fig. 23) and one group of cavate rooms are separated by almost a kilometer from the larger group of cavate rooms and the plaza site.

In addition to the sites listed above are other ruins or groups of ruins that warrant special interest. These are as follows. 


\section{LA 12655}

In his 1906 paper "Antiquities of the Jemez Plateau," Edgar Lee Hewettt wrote of this site (his site number 18), "...the best preserved ruin in this region." It still is the best preserved site in the region. The village had about 50 rooms, all apparently only one story high, built around a rectangular plaza (Fig. 28). It could be classified as one of the plaza sites, except that it is not so symmetrical as the other sites of that sort and it differs also in having no satellite ruins.

What makes it very distinctive is that the masonry is so excellent (Figs. 29 and 30) and that, unlike those of the other sites on the Plateau, the walls have not collapsed into mounds of rubble.
Aside from being interesting and photogenic, the ruin is also a puzzling one. It lies at the point of a mesita and was built on bare rock. There are two possible kivas (Fig. 28), but the surface evidence is not clear and, if the kivas are there, they were cut into the rock surface. Further, the village is about $200 \mathrm{~m}$ distant from the nearest soil that could be farmed, and this is unusual among Pajaritan setttlements, for they usually were located so that they were surrounded by arable land.

This site could be presented as an example of a village in a defensive location, but I believe that such a proposal could not be defended easily. True, the village's position on a high point of rocks above the junction of Canyon del Valle and Water Canyon at first appears to be defensive, yet the mesita above

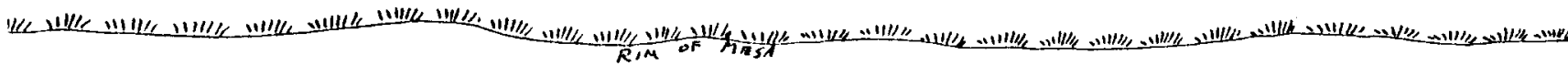

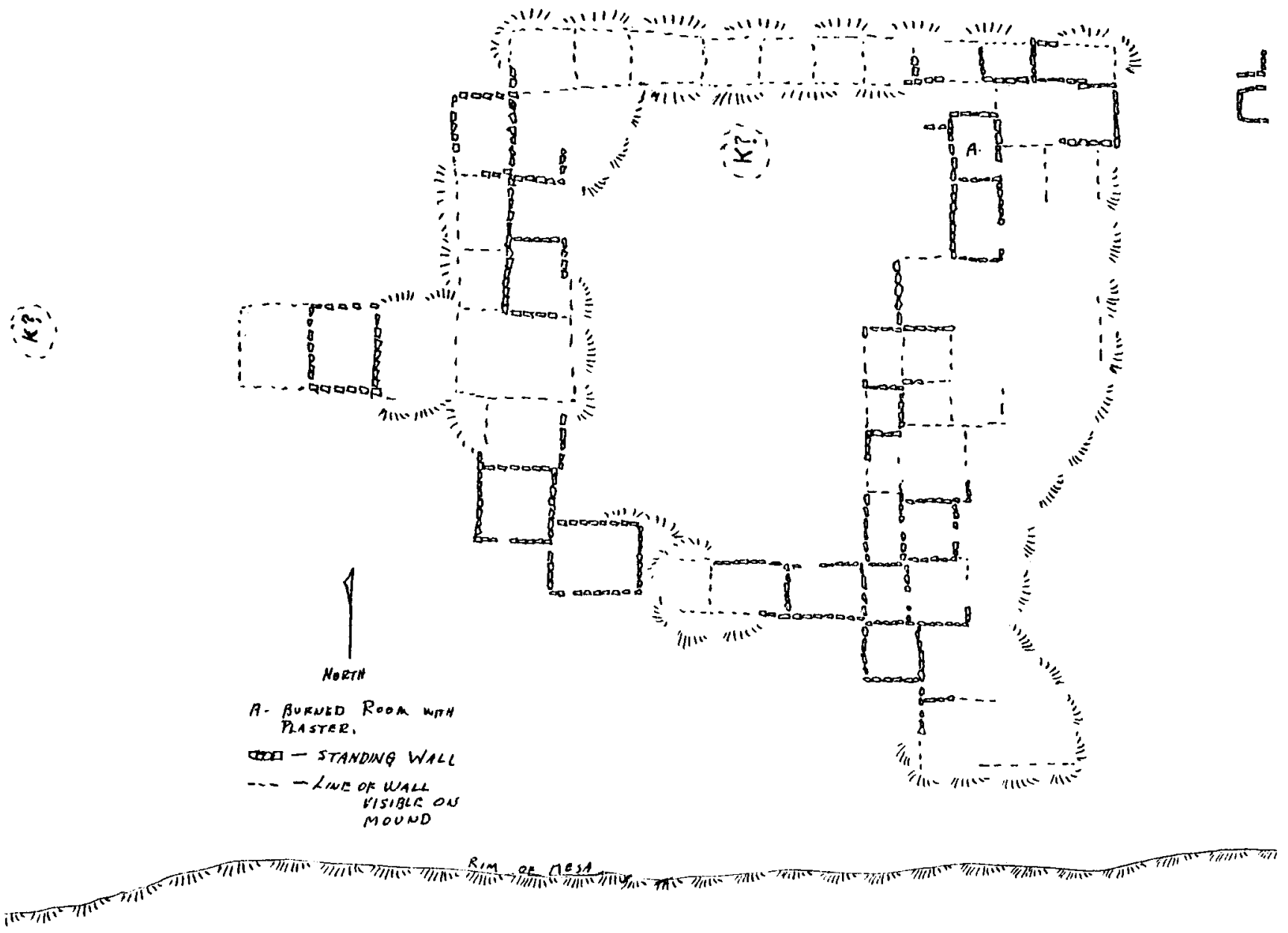

Fig. 28.

LA 12655 ground plan. 


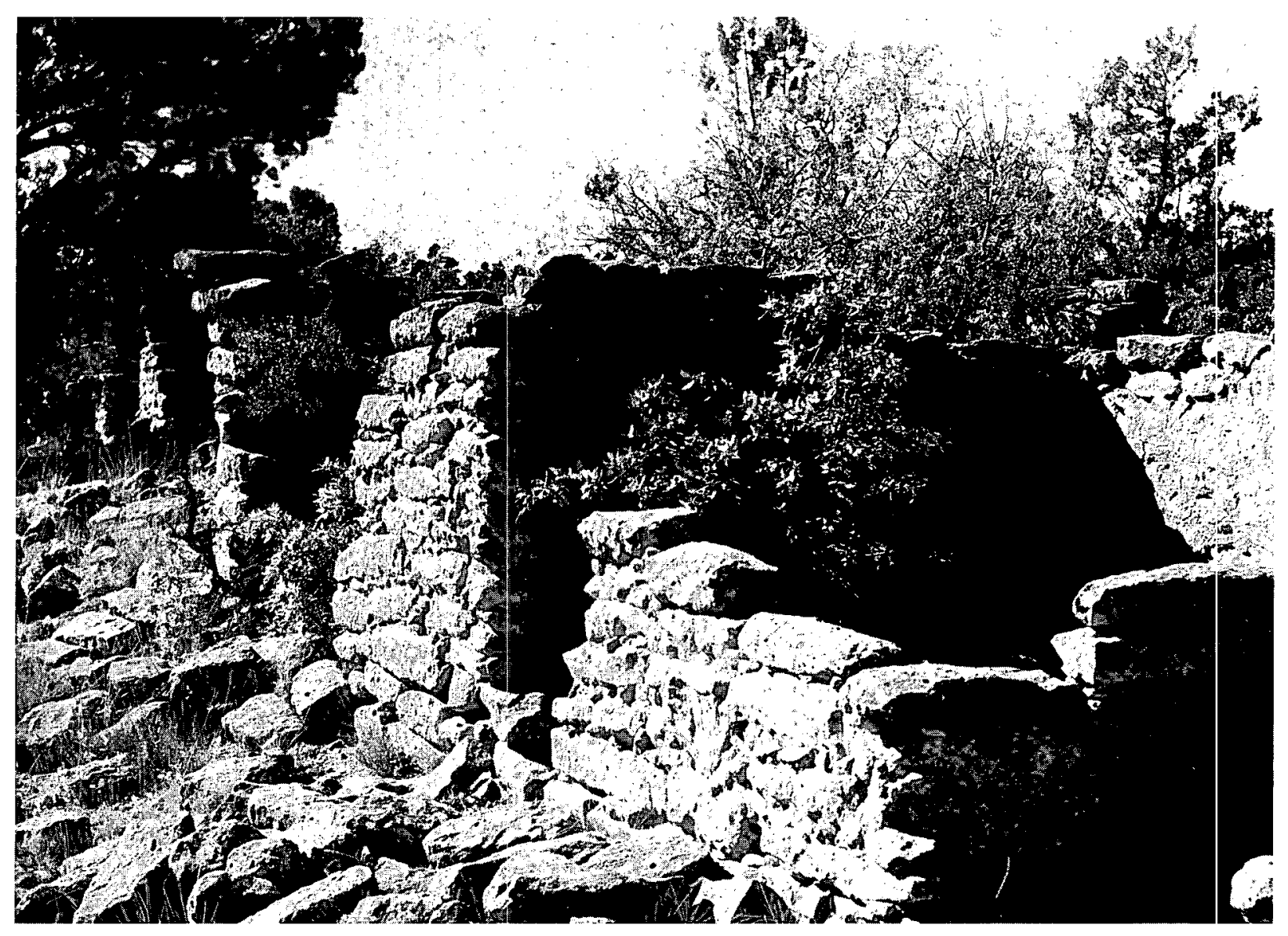

Fig. 29.

The walls of LA 12655 are of well-shaped stones laid in adobe mortar and chinked with spalls of tuff. Photograph by James R. Ditto.

the ruin to the west allows easy access to it, and there is no sign of any defensive work west of the site. The reasons for its location and its remarkable state of preservation are unknown.

In the room marked " $\mathrm{A}$ " in Fig. 28 is a large amount of wall plaster that shows finger marks of the person (presumably a woman) who applied the mud plaster. The reason for the preservation is that the roof of that room burned and the plaster was transformed into a low-grade ceramic. Even though exposed to the weather, the plaster has withstood the rigors of some 600 winters, but it seems to be deteriorating rapidly now. In the autumn of 1975 patching plaster was applied to the upper edges of the old plaster in an effort to slow the advance of erosion.
Little pottery is to be found at the site, but a few sherds of Santa Fe Black on White, Wiyo Black on White, and biscuit ware (Abiquiu and Bandelier Black on Gray) were gathered there.

\section{LA 4607 and Seven Other Sites}

Near the east end of the mesita south of Niortandad Canyon and near the point where Puye Drive drops into the canyon, is a line of eight ruins strung along the crest of the mesa. The largest of the sites, numbered LA 4607, is a plaza site. The mound of LA 4607 stands more than $2 \mathrm{~m}$ above the surrounding surface, and its plaza is more clearly delineated than those of most. (Most plazas seem to have been 


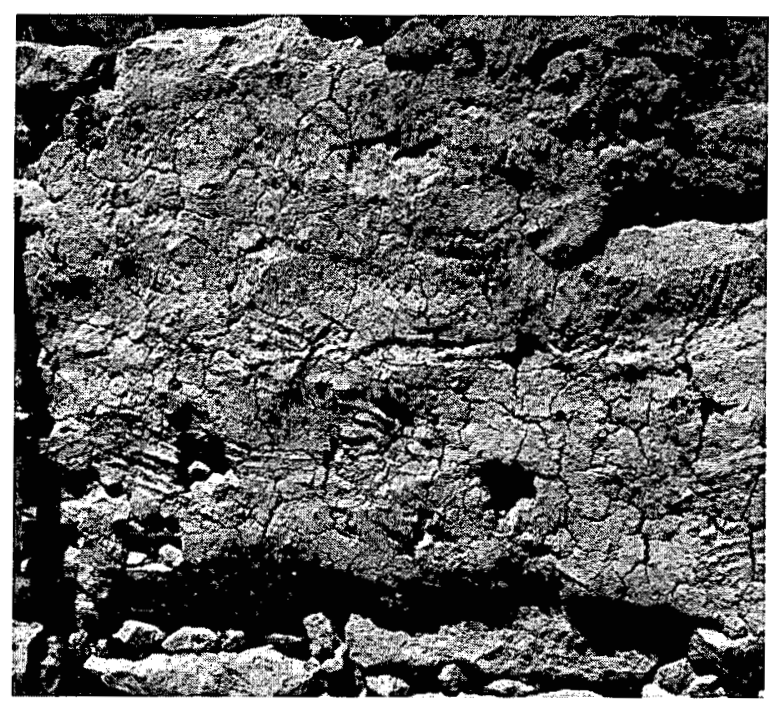

Fig. 30 .

The roof of one room burned, and the heat transformed the mud plaster into a low-grade ceramic that has preserved the finger marks of (presumably) the woman who plastered the wall.

cluttered with small rooms added after the main structure was completed.) There is a possible entry through the eastern section of the pueblo, a kiva within the plaza, and a possible kiva outside the structure near the southeast corner.

LA 4610, another ruin in this group, is either a plaza site or a U-shaped pueblo open to the south. The features are not so clear as at LA 4607. The other ruins in the group are those of small pueblos of one to three rows of rooms aligned, roughly, northsouth.

Only one ruin of this group, LA 4603, has suffered any major damage; construction of Puye Drive destroyed the nothern part of the site.

The sites appear to be contemporaneous and they form the largest, most complete plaza site complex within LASL lands.

\section{LA 4665 (PHERMEX Site)}

Within TA-15, adjacent to the PHERMEX facility, is a massive plaza site - perhaps the largest. The mound rises a little more than $3 \mathrm{~m}$ above the mesa top and it has three plazas - with a possible kiva in each (Fig. 31). The big site formerly stood in a cluster of several small dwelling units, but most of them have been damaged or destroyed by

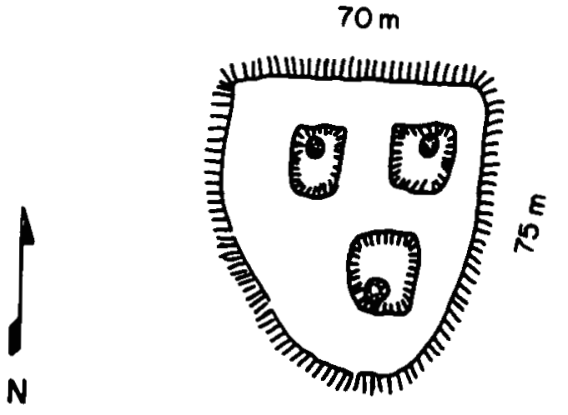

Fig. 31.

Ground plan of the PHERMEX site.

construction. Traces of several small sites can be seen, and Hewett (1906, p. 25) listed the PHERMEX site as his Site 17 and said "it was once the center of numerous small sites."

The masonry at LA 4665 is exceptionally good, and on the west side the building probably stood three stories high. A peculiar feature is that the rooms are much smaller than is usual on the $\mathrm{Pa}$ jarito Plateau.

\section{LA 12700 (Guaje Site)}

An extensive group of ruins lies on the high mesa north of Guaje Canyon and east of the Pajarito Trail. It consists of at least seven ruins (the actual count depends on the person counting) which are strung out for about $550 \mathrm{~m}$ along the crest of a narrow high mesa.

Figure 32 portrays the layout of the ruins. As one approaches from the west, the first three groups of houses present no particularly interesting features. At the ruin marked "D," however, one meets a real puzzle. In plan, this ruin is somewhat like a dam and there is a small wet weather pond in the angle. The ruin lies at the crest of a narrow ridge, however, and there is little drainage into the angle formed by the walls. The exposed masonry of this structure is excellent, and of dressed stone. There appear to be no cross walls within the structure; it is probably a thick structure faced with excellent masonry and with a rubble fill. A real puzzler!

East of that is ruin E, a U-shaped pueblo open to the east; F, a large plaza site with three rock-cut kivas; and G, which can be considered either another U-shaped structure open to the south or another plaza site. There are also two rock-cut kivas in $\mathrm{G}$. 


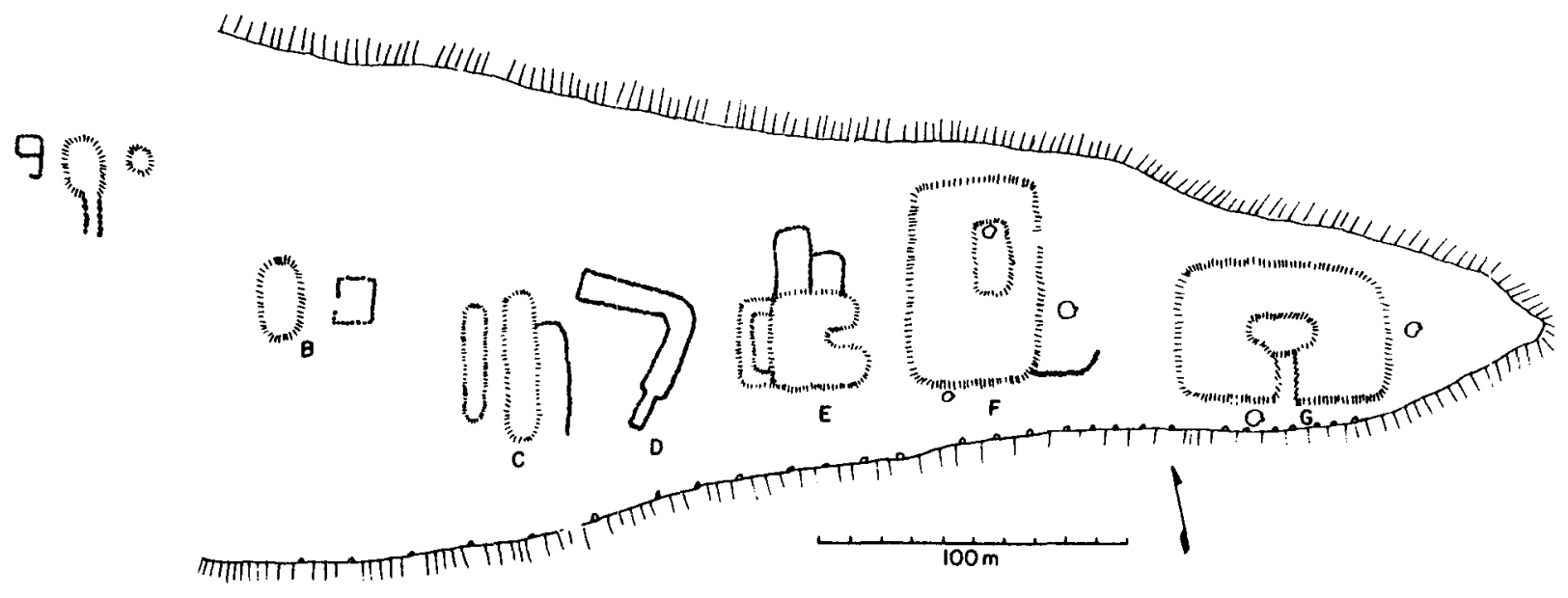

Fig. 32.

Ground plan of LA 12700.

At the base of the low cliff that borders the site to the south is a string of perhaps 50 cavate rooms. At least half seem to have been ceremonial rooms. Passage between the mesa-top structures and the houses on the slope below was made by several toehold steps and by at least two wide flights of stairs (see Fig. 26). Unfortunately, recent rock falls have almost completely destroyed the stairs.

A strange thing about this site is that it is at an elevation of more than $2275 \mathrm{~m}$ (more than $7400 \mathrm{ft}$ ), it is in a forest that is largely ponderosa pine, on a mesa top that has little arable land, and much of it is probably above an elevation where garden crops can be grown. Yet a population of at least a couple of hundred people must have lived here.

This site is within the Santa Fe National Forest, and the Forest Service is making a study of the area between LASL lands and the Santa Clara reservation to determine whether to create an archaeological protection zone there.

\section{SOME THOUGHTS ON PAJARITAN ARCHAEOLOGY}

A question about Pajarito archaeology which arises early is that of the population. Why, after what was probably several thousand years of casual and intermittent use by parties of hunters, was there an apparently sudden influx of Puebloan Indians onto the Plateau in very late Pueblo III times - about or slightly before $\mathrm{AD} 1300$ ?
In the San Juan Basin (the heartland of A.nasazi cultural development), the drought-ridden 13th century was over. The puebloan population there had shrunk drastically during the last half of the century. Large areas were abandoned, and the remaining population was concentrated west of the Chuska Mountains and in the present day Hopi country. At the same time, the peoples of the Rio Grande were expanding rapidly - both in numbers and in occupied area.

The 13th century drought was not so severe in the Rio Grande drainage as farther west, and the 14th century saw a period of optimum conditions for primitive farmers in the Rio Grande Valley and on the southern plains.

There was a spurt of building activity in previously unoccupied or lightly inhabited zones within the valley (Wetherington 1968), and pueblo settlements moved eastward onto the Rocky Mountain piedmont and the plains. In some areais, they mingled with settlers from the Republican River Valley who were also attracted to the southern plains by favorable climatic conditions (Krieger 1946).

Pueblo III pottery of the upper Rio Grande was strongly influenced by that of the San Juan and Little Colorado Valleys. In the modern Tewa area, the styles were patterned after the Mesa Verde Black on White, and in the Queres and Tiwa area, parent styles are to be found in the Zuñi and Gallinas districts. A number of southwestern archaeologists 
argue from these facts that late in Pueblo III times there were migrations of people from the San Juan to the Tewa part of the Rio Grande, and from the Gallinas drainage to Queres and Tiwa country.

Among those who have suggested such population movements to help explain the quick expansion of Rio Grande peoples in the late 13th and early 14th centuries are Reed (1950 and 1951), Wendorf and Reed (1955), and Ellis (1964). Their studies were based primarily on distribution of pottery types and gave little consideration to other cultural traits.

It must be recognized that the ceramic craft, and the decoration of pottery vessels, is an art form that can be passed quickly and easily from one cultural group to another. No movement of people, other than a few individuals who could be traders, is necessary to transmit a trait of this sort.

For a population to move from one area into another that is already occupied ensures conflict. Ellis (1964) says that some of the Pueblo IV sites in the vicinity of Nambe were fortified, and there are Nambe stories of attacks on them but no word about the identity of the attackers. As a general rule, Puebloan sites in the Rio Grande are not fortified, and on the Pajarito Plateau there is no single village location that seems to have been chosen for defense.

Mera (1934) classified some Rio Grande villages as being in defensive, semidefensive, or unprotected positions. Tshirege, for instance, is listed as semidefensive, presumably because it is located on a mesa top. The mesa is a low one and the site is readily approached from every direction, including the long slope of the mesa west of the ruin. In addition to the house blocks on the mesa top is the long, almost continuous line of masonry houses and cavate rooms that stretch along the low cliffs on the south face of the mesa. These houses, as much a part of the ancient village as the houses on top, would have been fully exposed to any attack.

The impression one gets is of a wide-spread community that had few troubles with peoples outside the Rio Grande. Trade relations with other southwestern areas, notably with the San Juan and Zuñi-Gallinas areas, must have been free and open to account for the ready acceptance of art styles from the west. A long, critical look at the locations of the ruins on the Pajarito Plateau fails to reveal any real defensive position. Even sites such as LA 12655 and LA 12700 which are in high positions, seem to have been placed where they are for some reason other than defense.

The rapid expansion of population, and the extension of areas occupied by the Rio Grande pueblos must be explained by causes other than an immigration of new people. The cause offered here is what we call today a "population explosion" triggered by favorable economics brought on by climatic conditions that allowed the Rio Grande peoples to carry on nonirrigation farming in previously uncultivated areas. In periods of plenty, populations tend to expand rapidly, just as, when famine and disease are prevalent, an area's people rapidly dwindle in number.

There are two strong indications that the rapidly expanding Rio Grande population grew from the indigenous settlements along the river.

1. In Pueblo II times, a distinctive type of construction was developed in the Rio Grande. It was the sort of building described in the Appendix as adobe. This became the standard construction method along the upper Rio Grande throughout the Pueblo III period and it persisted into Pueblo IV. Near the end of Pueblo III, the Indians of the Mesa Verde, who have been nominated as a possible foreign element in the 13th and 14th century Rio Grande population, were building with a distinctive and rather sophisticated form of masonry. When Pueblo Indians settled on the Pajarito Plateau, they built their homes of adobe. There is no hint of Mesa Verde masonry on the Pajarito Plateau, or in the Rio Grande Valley, for that matter; building was done entirely in the local tradition.

2. The design of kivas or ceremonial rooms also was home-grown. In the Mesa Verde cultural area, Pueblo III kivas were distinctive and standardized. A kiva's position in a village or house block was predictable; a kiva, either subterranean or partly so, was generally surrounded on three sides by dwellings and storage rooms. The block of rooms with a kiva was usually open on the south or east side.

The Rio Grande ceremonial room, on the other hand, frequently has no kiva features, and until well into Pueblo IV times it was built entirely above ground. Frequently the only feature that indicates a room of more than ordinary household use is that a room in a house block is somewhat larger than the others, or, most frequently, has a curved wall that makes it D-shaped (see room plans for Site LA 4715 in Worman and Steen). 
As stated above, these rooms sometimes have no features that indicate ceremonial use, but usually there is an extra-large fire pit, a masonry altar, or some other feature of unexplained use, so they are commonly called ceremonial rooms. This, it must be remembered, was at a time when kivas farther west had most distinctive features. Apparently, the kiva cult was not introduced into the upper Rio Grande until well into Pueblo IV times, when ventilator shafts, sipapus, foot drums, and other kiva features were built into semisubterranean kivas. The earlier structures, those built at the time of the great expansion, were simple rooms built entirely above ground as Rio Grande ceremonial chambers had been for the preceding two hundred years or more.

There is always a danger in making such flat statements. Snow (1974) excavated a Mesa Verde type kiva at Salt Bush Pueblo in Frijoles Canyon. The dominant painted pottery at Salt Bush Pueblo was Santa Fe Black on White. Nothing like that has been found on the Pajarito Plateau north of Frijoles Canyon, and the question of linguistic, tribal, and cultural boundaries must be considered. As Bandelier (1890-92), Lange (1959), and others have pointed out, Queres and Tewa legends agree that Queres people lived in Frijoles Canyon and in the region to the south, whereas Tewa-speaking peoples lived north of Frijoles. The kiva at Rainbow House (Caywood 1966) has no Mesa Verde characteristics, and other kivas in Frijoles Canyon, all of which were later in time than the Salt Bush kiva, were dug early in this century so there are no adequate records of their features. There are no records of excavated kivas on the Pajarito Plateau south of Frijoles Canyon, so we do not know if the Mesa Verde features at Salt Bush Pueblo were duplicated at other Pueblo III sites in Queres Territory.

\section{ACKNOWLEDGMENTS}

A project of this sort cannot be carried through to completion without material assistance from many people. Almost the entire staff of the Envirormental Studies Group (H-8) of LASL's Health Division participated to some degree in the survey. Other LASL staff members who contributed time and advice and shared their knowledge of the Pajarito Plate:au were William Davis, James R. Ditto, Gary D. Doolen, Paul R. Franke, Jr., Henry J. Fullbright, Carroll B. Mills, Barton W. Olinger, John B. Ramsay, and Raymond N. Rogers. To all these people I am grateful. 


\section{APPENDIX \\ SITES EXCAVATED ON THE PAJARITO PLATEAU \\ 1950-1974}

This Appendix contains the available information about sites known to have been dug by Worman and others between 1950 and 1974, except those reported in Worman 1967 and Worman and Steen, in press. Notes on some of these excavations are sparse, and for a few the only data have been garnered from photographs made at the time of digging. For most of the sites, the LASL Engineering Department made ground plans which are reproduced here. In two instances, there are discrepancies between the Engineering Department plan and rough sketches in a Worman notebook. The differences apparently result from an additional room's being dug after the engineers had left the site - for those sites, both drawings are reproduced here.

The LASL drawings are gathered into 13 numbered sheets, ENG-R-4443 through ENG-R4455. They include one sheet (ENG-R-4443) of the Los Alamos grid which shows the locations of all the sites that Worman surveyed.

In addition to the sites that Worman dug, this Appendix also includes descriptions of two sites, LA 170 and LA 8681, dug by the Los Alamos Archaeological Society and of three small sites, LA. 4630, LA 4722, and LA 13286, that I dug in 1974 and 1975.

\section{Wall Construction}

This is probably the best place to describe briefly the types of wall construction used by the Indians of the Pajarito. One type is termed "adobe" hereafter, and a second type is called "masonry" with qualifying descriptions of the type of stone used.

Adobe. The Pajaritans used no molded bricks. The most common way to build a wall in the 13 th and 14th centuries was first to dig a shallow construction trench the width of the projected wall and then to make a form of pise or rammed earth. A row of rough tuff boulders was placed in the trench, and then mud was slapped and pressed in place around them to form the base of the first course of the wall. The first course, and subsequent courses, were usually $30-40 \mathrm{~cm}$ high. When the first course was dry, others were added and each was allowed to dry until the desired wall height was reached. Frequently chunks of tuff were placed at random in the wall, probably to help get the wall up quickly and save work. Some walls were built without laying the row of stones in the construction trench.

Masonry. The evidence now available indicates that the earliest masonry walls were of unshaped pieces of tuff laid in adobe mortar. Later, probably beginning late in the 14th century, much of the masonry was of finely shaped pieces of tuff (see Fig. 29) wedged or chinked with spalls of stone and laid with adobe mortar.

Except for the apparent difference in the times at which the types of masonry were introduced, there seem to have been no restrictions on construction methods. In later times, both earthen and stone walls are found in the same structures; sometimes stone walls were added to adobe, and, just as frequently, adobe-walled rooms were added to masonry structures.

\section{DETAILED SITE DESCRIPTIONS}

\section{Site LA 170 (Tshirege Cave)}

Location: Cavate rooms and talus houses or south face of Tshirege Mesa.

Excavated by: Los Alamos Archaeological Society, in 1956-57. 
The ruin: Thirteen masonry-walled rooms and six cavate rooms were dug. There is a manuscript report by Dwight Young (1957), and Maxon (1968) reported on the dig at length.

Pottery: Maxon listed and discussed the pottery recovered from this site. It ranges in type and time from Santa Fe Black on White to the glazed paint wares.

Ground plan: None available.

\section{Site LA 4611}

Location: SE1/4, SE1/4, Sec 22, T.9N, R.6E. The site was on the mesa between Mortandad Canyon and Cañada del Buey, at the location of the transformer station on Puye Drive.

Excavated by: Frederick C. V. Worman, April 1617, 1968.

The ruin: This was a structure of five rooms (Fig. A-1), one of which was remodeled to make a narrow room with a rounded end. A fireplace was found in only one room; it consisted of four large stones placed on the floor in the northwest quadrant of the room. Except for the remodeled room, the walls were of adobe. The later wall was of masonry that contained both shaped and unshaped stones, as though they had been gathered from two or more earlier sites. An ash lens lay under the east wall of Room 1 (Fig. A-2).

Pottery: Santa Fe Black on White and Abiquiu Black on Gray.

Stone artifacts: Broken manos and metates, floor anvil.

Drawing: LASL ENG-R 4447. This is one of the sites for which there is a discrepancy between Worman's sketch and the Engineering Department drawing (Fig. A-3).

Site LA 4630

Location: In Area G, TA-54, lower (east) end of Mesita del Buey in quadrant S8 E14 of the Los Alamos grid.

Excavated by: Charlie R. Steen, June 3 and 4, 1974.

The ruin: LA 4630 was a small two-room structure on Mesita del Buey. Frederick Worman located and

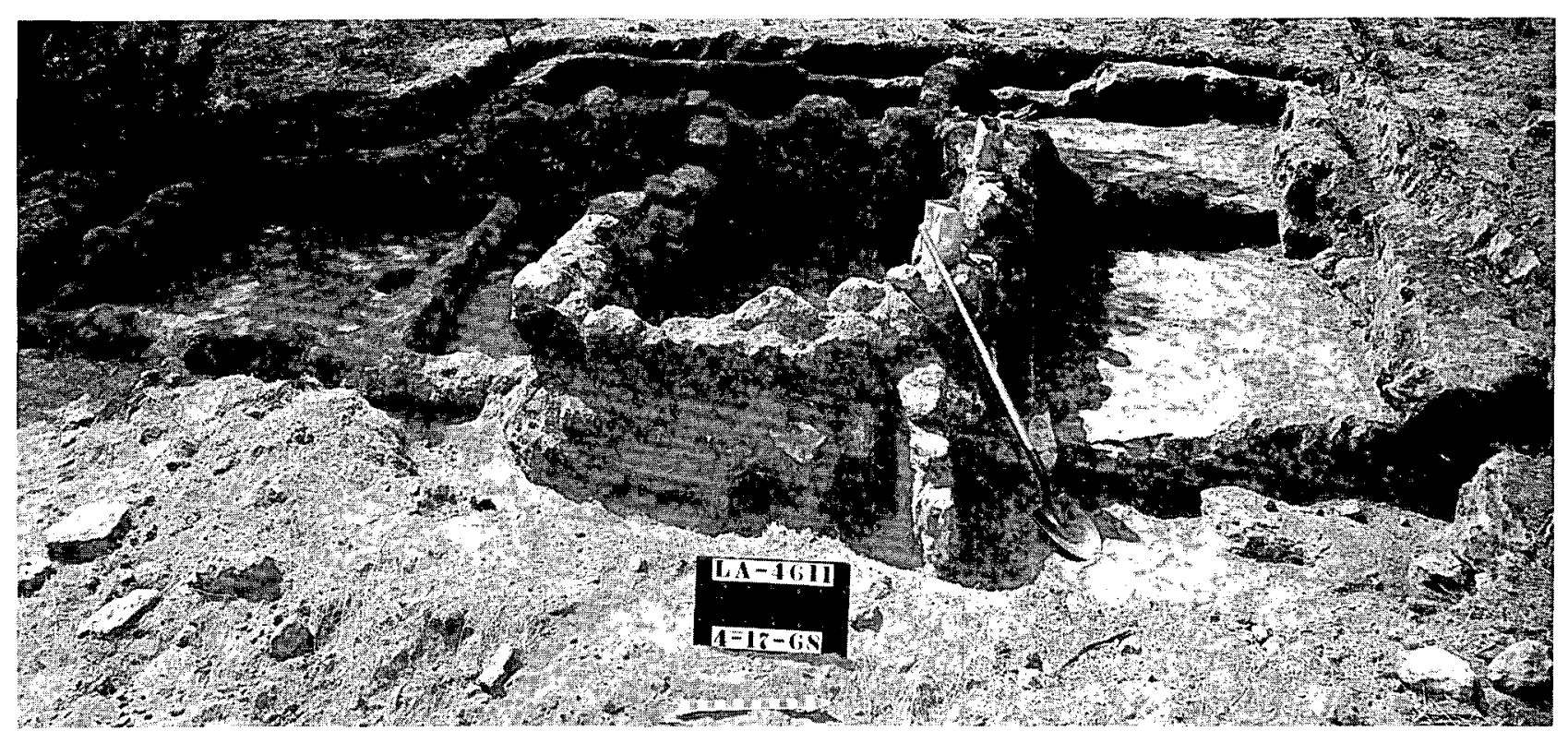

Fig. A-1.

Site LA 4611. 


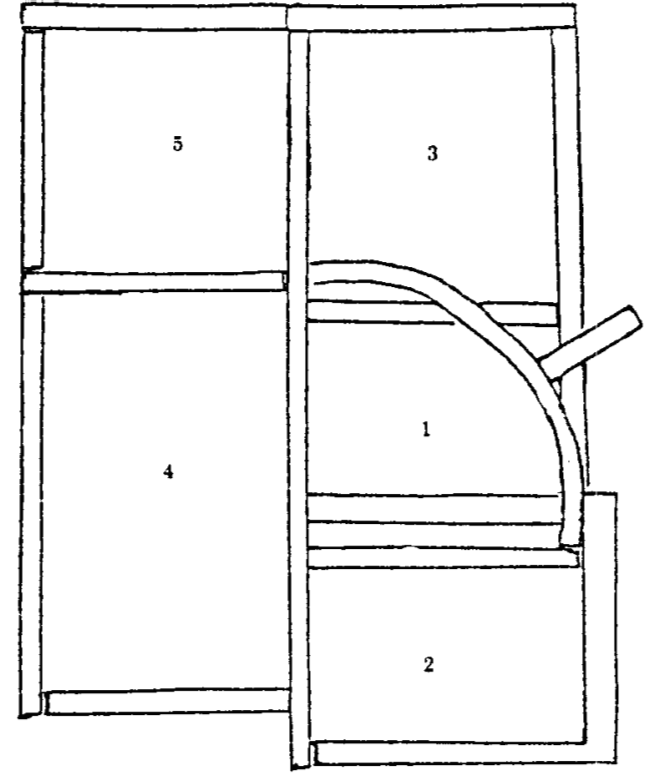

Fig. A-2.

LA 4611 sketch for Worman's notebook.

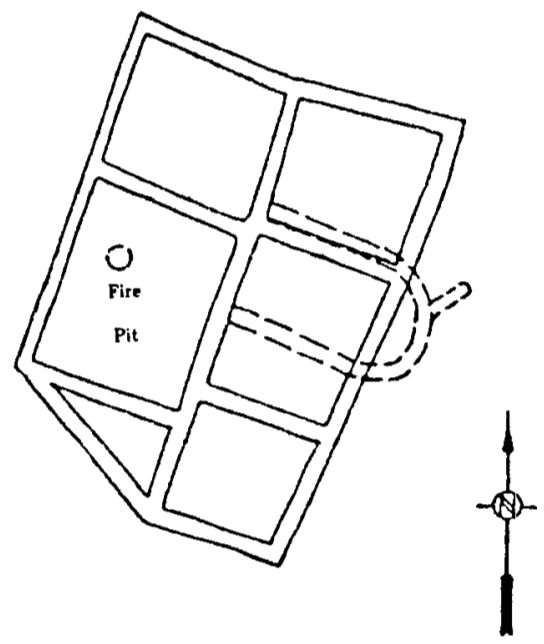

Fig. A-3.

LA 4611 drawing prepared by LASL Engineering Department.

numbered it in 1957 during a survey of the mesita, and, later that year, he dug four sites in the vicinity as an archaeological salvage project (Worman 1959, 1967). LA 4630 was near the sites dug in 1957 , but it was not then in the path of construction. It was not until the summer of 1974 that extension of the facilities on Mesita del Buey made it necessary to excavate the site.
Two rooms were found by the excavations; formerly there may have been one or two additional rooms but they were obliterated, probably by Indians during pre-Columbian times. Neither room had a firepit or a well-defined floor. The walls were somewhat unusual for a small Pajarito farmstead of the time when Santa Fe Black on White was the dominant ceramic type. They were built of finely shaped blocks of tuff - a style that apparently did not become common on the Pajarito until near the end of the 14th century. One cannot be too sure of the masonry type because the walls at the time of excavation were only one course high, as though the stone had been pirated for construction elsewhere. To support this argument, in each room was ca small group of masonry blocks lying at floor level as though they had been taken from the walls but not hauled away to another site.

Adjacent to the west side of the building was a bowl-shaped pit a half-meter in diameter and the same measure in depth (Fig. A-4). The soil within the pit was impregnated with charcoal, but the only object found in it was a single sherd of Wingate Black on Red. Two meters west of the building was an arc of small stones that may once have served as the base for a windbreak of brush (Fig. A-5).

The mesa topsoil in this vicinity is only $0.3-0.5 \mathrm{~m}$ deep.

Pottery: Only 58 sherds were recovered from this site. They were:

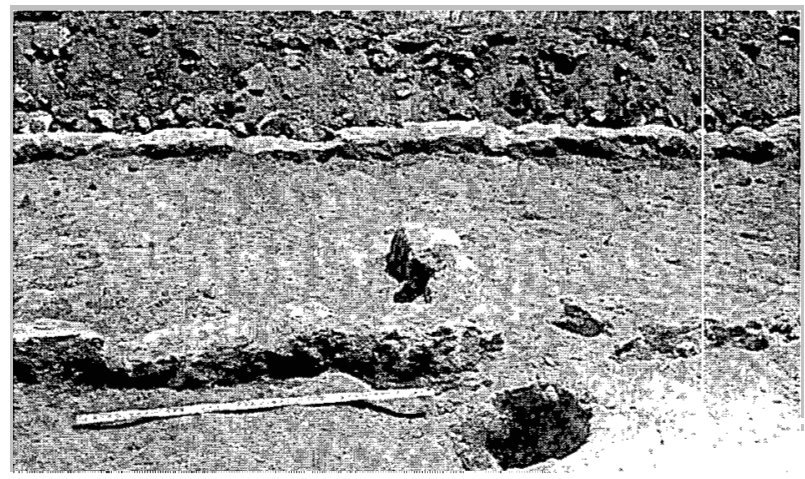

Fig. A-4.

Part of LA 4630, looking east and showing the position of the pit near the west wall. (Meter stick included.) 
Santa Fe Black on White

With thin white slip

Without slip

bowls 13

Wiyo Black on White

Wingate Black on Red

bowls 3

bowls 1

bowls 1

Rio Grande Corrugated jars 40

Stone artifacts: Stone artifacts were as sparse as potsherds. Three tools were found:

1 scraper/plane of light gray quartzite

1 crude scraper of traprock

1 chopper of a dark chert.

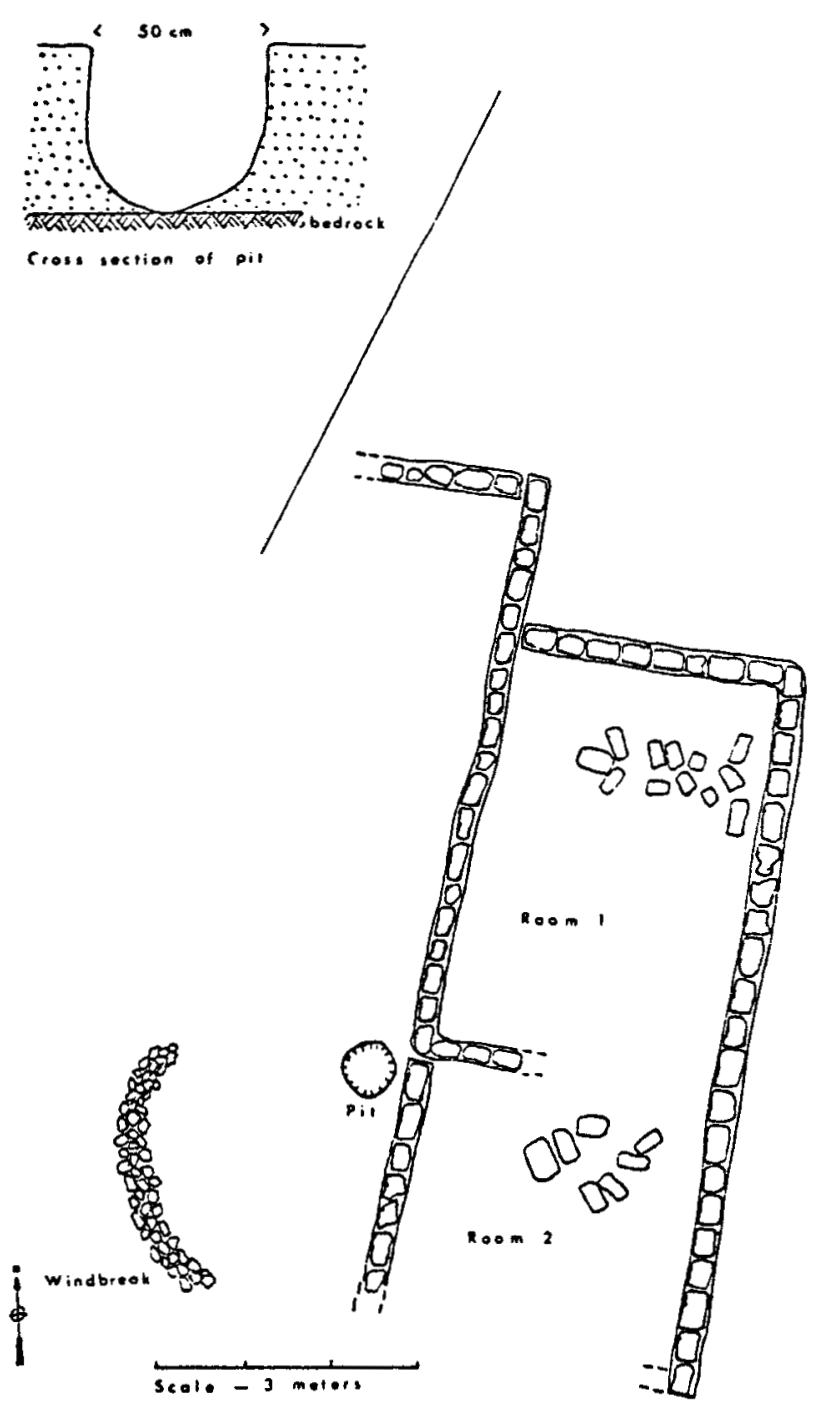

Fig. A-5.

Plan of LA 4630 with profile of pit.
Site LA 4634

Location: Within TA-46. In quadrant N 1 E8 of the Los Alamos grid.

Excavated by: Frederick C. V. Worman, July 29August 2, 1963.

The ruin: This was an eleven room site with two parallel rows of five rooms each and one room projecting from the east side (Fig. A-6). At least two rooms had walls of adobe, but most of the walls were of masonry. The masonry was of large unshaped tuff blocks. One room had a flagstone or stone floor. Four rooms probably had firepits; the pits were all round in plan, 15-18 in. in diameter and 3-8 in. deep. They had flat plastered bottoms, and the rims were raised about two inches above the floor level (Fig. A-7).

Pottery: Photographs of two probable Santa $\mathrm{Fe}$ Black on White bowls were taken at the time of the excavation. One incomplete bowl had a diameter of $7 \mathrm{in}$. The second bowl's rim had been pressed into a square shape (Fig. A-8), about $5-1 / 2$ in. to a side. No sherd count was made at this ruin.

Stone artifacts: Broken metates and manos, including one heavy trough metate and several broken thin slab metates, two tapered tuff plugs for holes in walls, a full grooved maul, and a possible pebble hammerstone, can be identified from the photographs (see Fig. A-9).

Drawing: LASL ENG-R 4447 (Fig. A-10).

\section{Sites LA 4637 and LA 4638}

Location: Near Uhtrex Facility on Puye Drive. In quadrant N3 E7 of the Los Alamos grid.

Excavated by: Frederick C. V. Worman, September 5, 1961.

The ruins: These were one-room structures; each had a single course of well-shaped stones as a basal course and a few small unshaped tuff blocks used as fillers in adobe walls. There seemed not enough of the latter to carry the walls more than $15-20 \mathrm{~cm}$ higher than the base course. These may have been box-type shrines. 


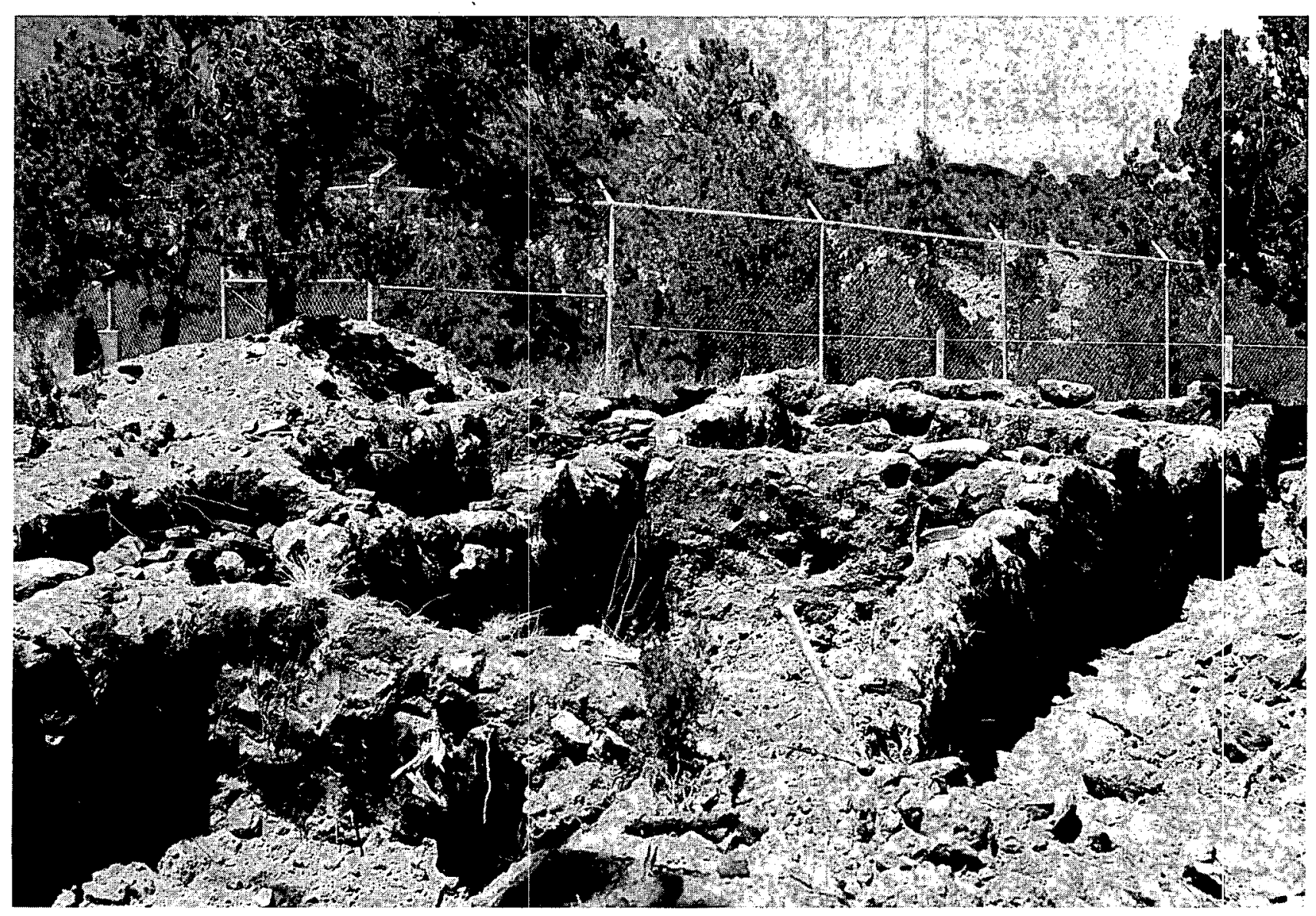

Fig. A-6.

Excavated rooms at LA 4634.

Pottery: None reported.

Stone artifacts: None reported.

Drawing: Only rough sketches by Worman were made; they are not reproduced here because Figs. A11 and A-12 show the features of the sites very well.

\section{Site LA 4658}

Location: At the upper end of Mesita del Buey in quadrant N1 E7 of the Los Alamos grid.

Excavated by: Frederick C. V. Worman, June 8, 1964.

The ruin: This was a one-room structure with three courses of well-laid masonry of shaped tuff blocks (Fig. A-13). Enough stone lay around the room to carry the masonry up one or two more courses. There were no other features. This may have been a boxtype shrine.

Pottery: A surface collection included Santa Fe Black on White, Wiyo Black on White, intermediate Wiyo-Bandelier Black on Gray, and an early glaze.

Stone artifacts: None reported.

Drawing: LASL ENG-R 4449, labeled LA 4659 (Fig. A-14).

\section{Site LA 4659}

Location: At the upper end of Mesita del Buey, probably in the right-of-way of Pajarito Road.

Excavated by: Frederick C. V. Worman in June 1964. 


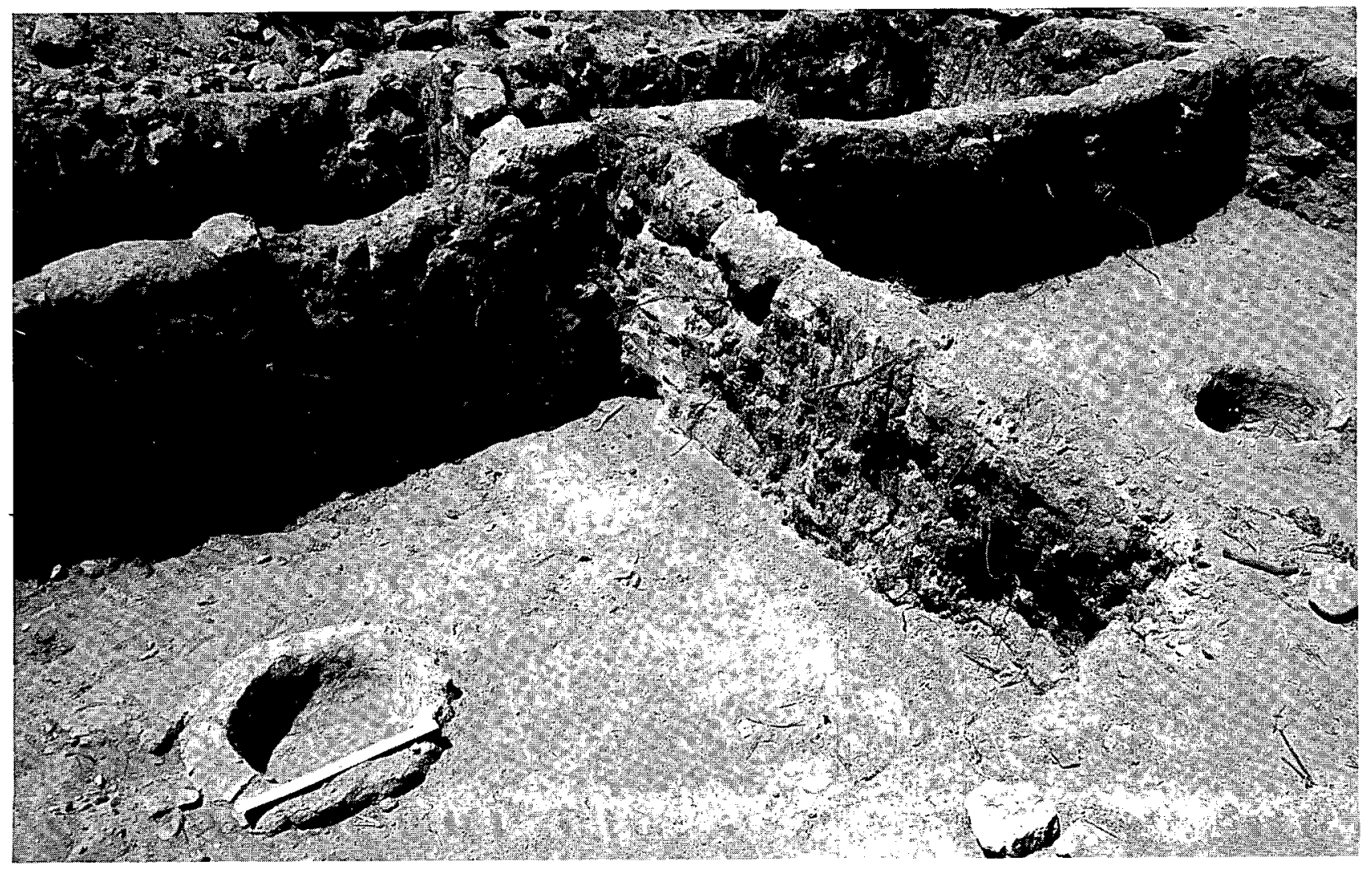

Fig. A-7.

Excavated rooms at LA 4634, showing firepits.

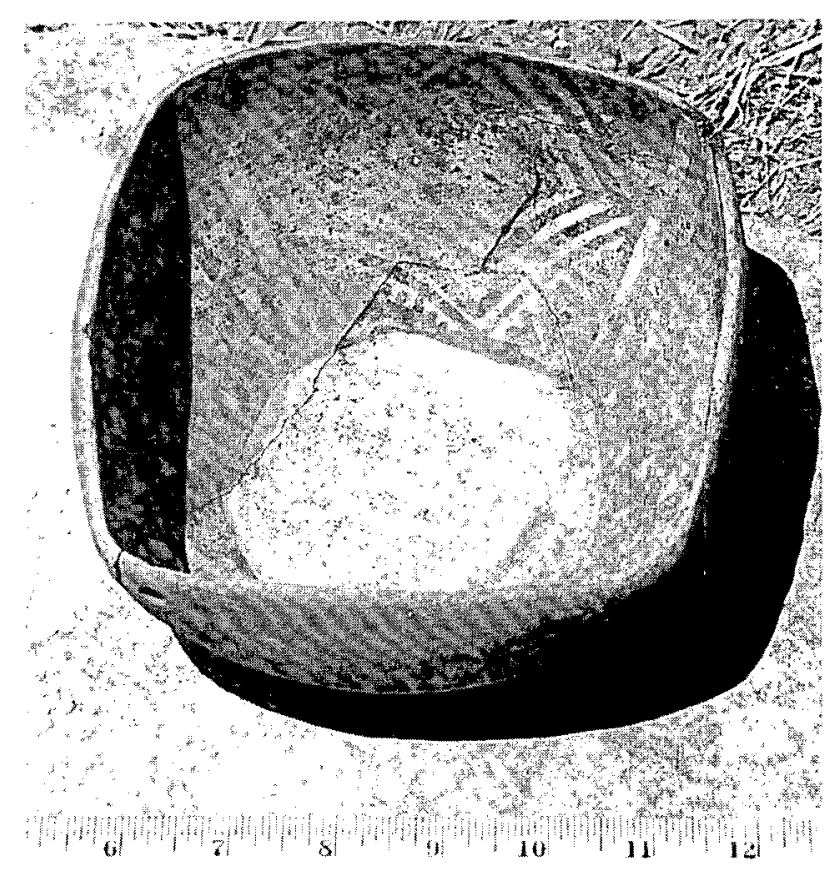

Fig. A-8.

Santa Fe Black on White bowl from LA 4634. 


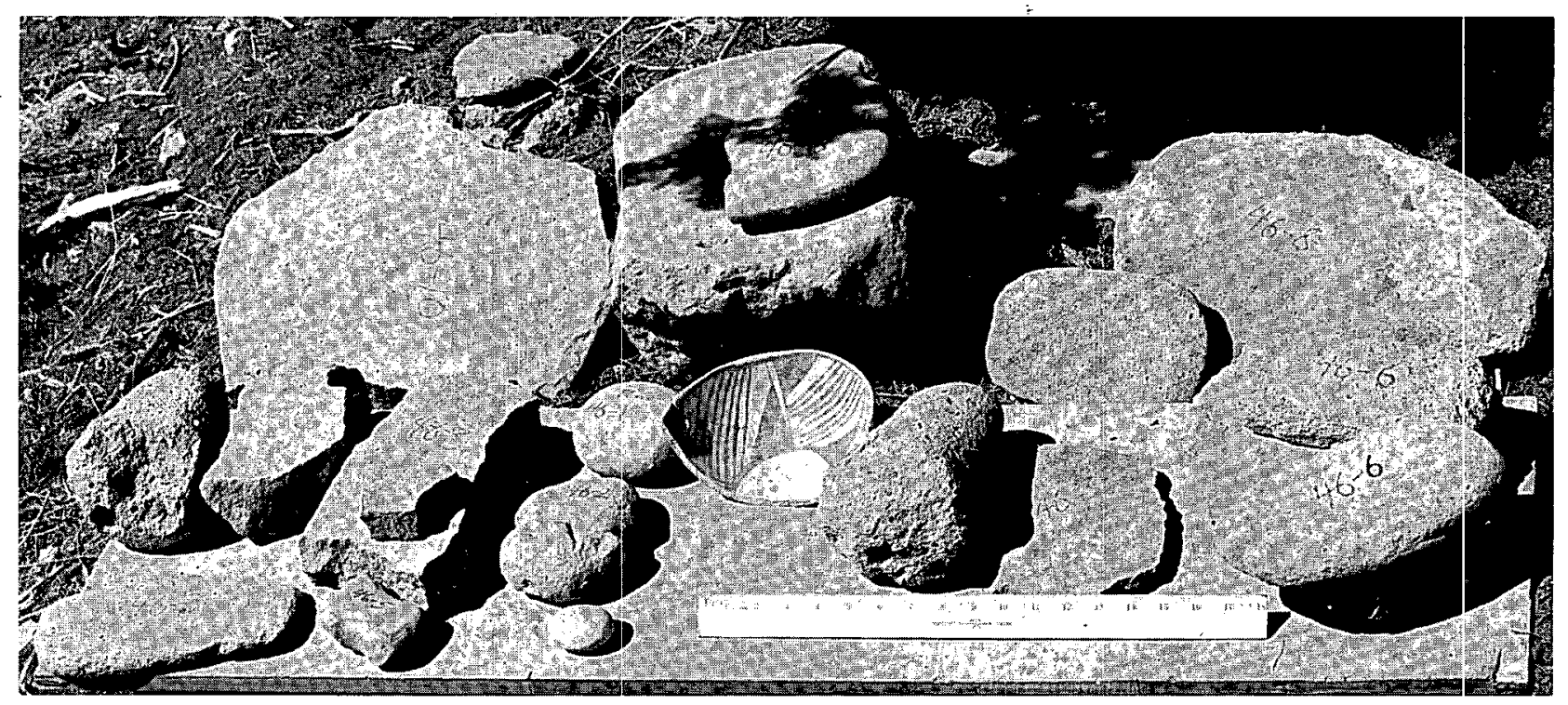

Fig. A-9.

Artifacts recovered from $L A 4634$.

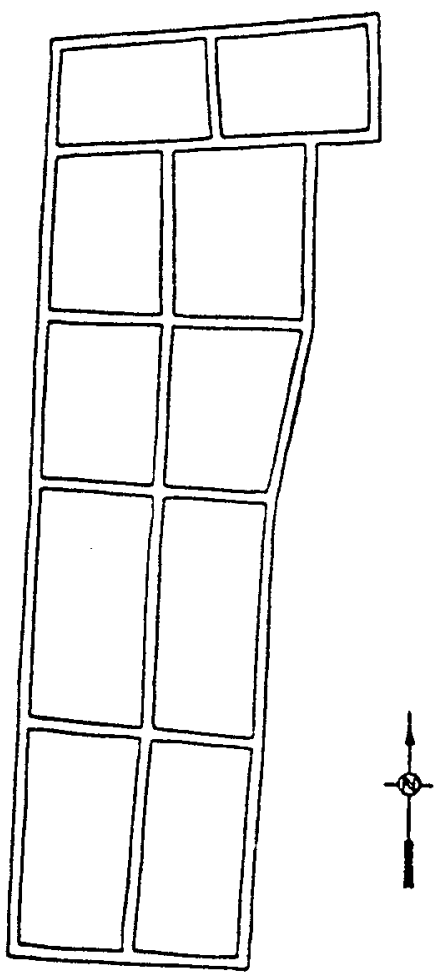

Fig. A-10.

LASL Engineering Department drawing of LA 4634 showing only 10 rooms.
The ruin: This was a 16 -room pueblo, with a kiva included in the room count (Fig. A-15). Some walls were adobe, and some were tuff block masonry; the blocks were large and unshaped. A vent and a blocked doorway between rooms are shown in Fig. A-16. A firepit in room 10 was filled (with earth?) and plastered over (Fig. A-17). There was no ventilator in the kiva (Fig. A-18).

Pottery: None recorded.

Stone artifacts: None recorded.

Drawing: The ground plan of this site is shown in ENG-R 4448 as LA 4658 (Fig. A-19).

\section{Site LA 4660}

Location: The original survey sheet for this site said it was in "Pajarito Canyon - north side canyon bottom." Photos taken during excavation were wellplacarded and show the site on top of a mesa. It was probably destroyed by construction of Pajarito Road.

Excavated by: Frederick C. V. Worman, June 8, 1964. 


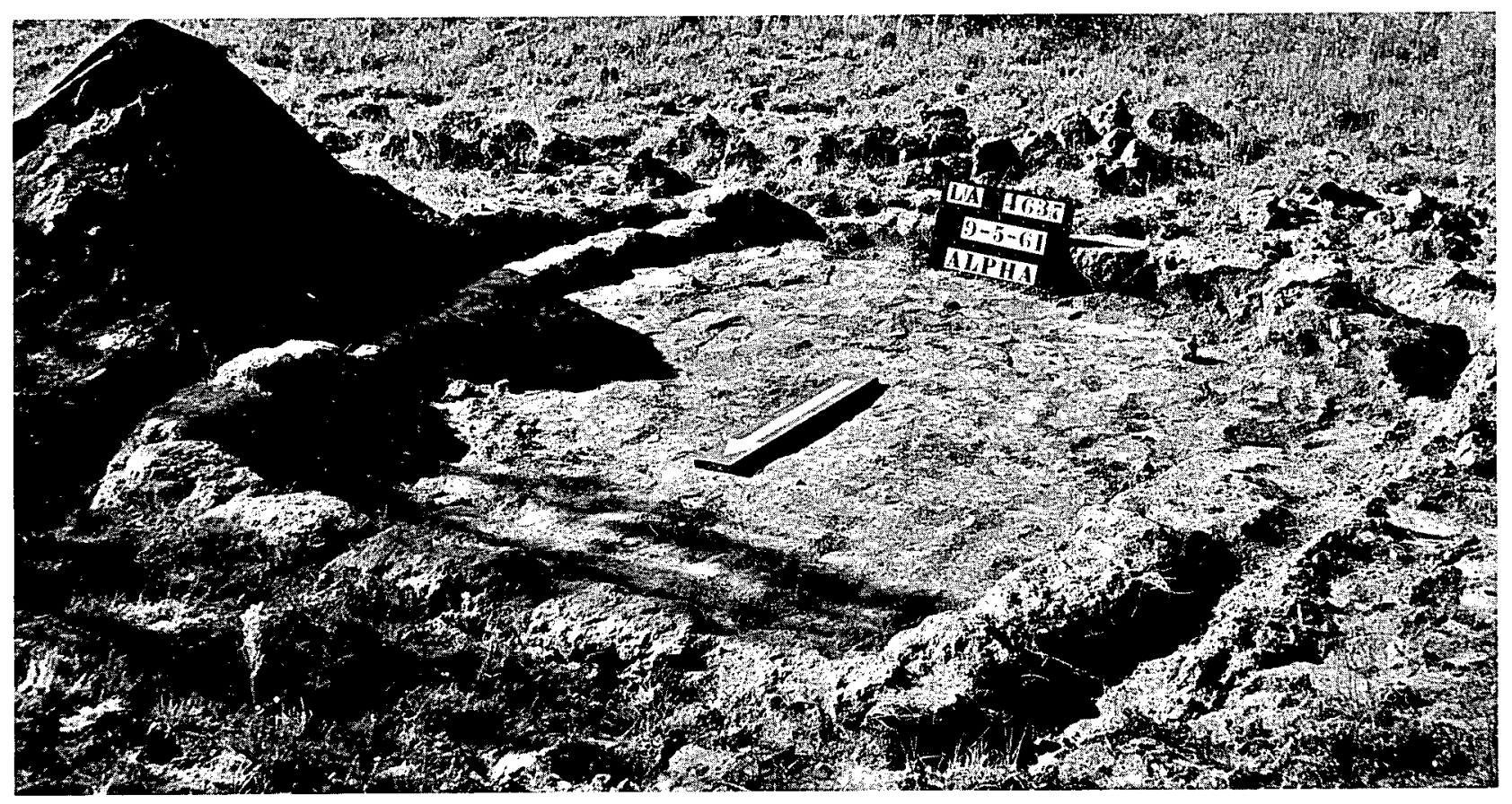

Fig. A-11.

LA 4637 after excavation.

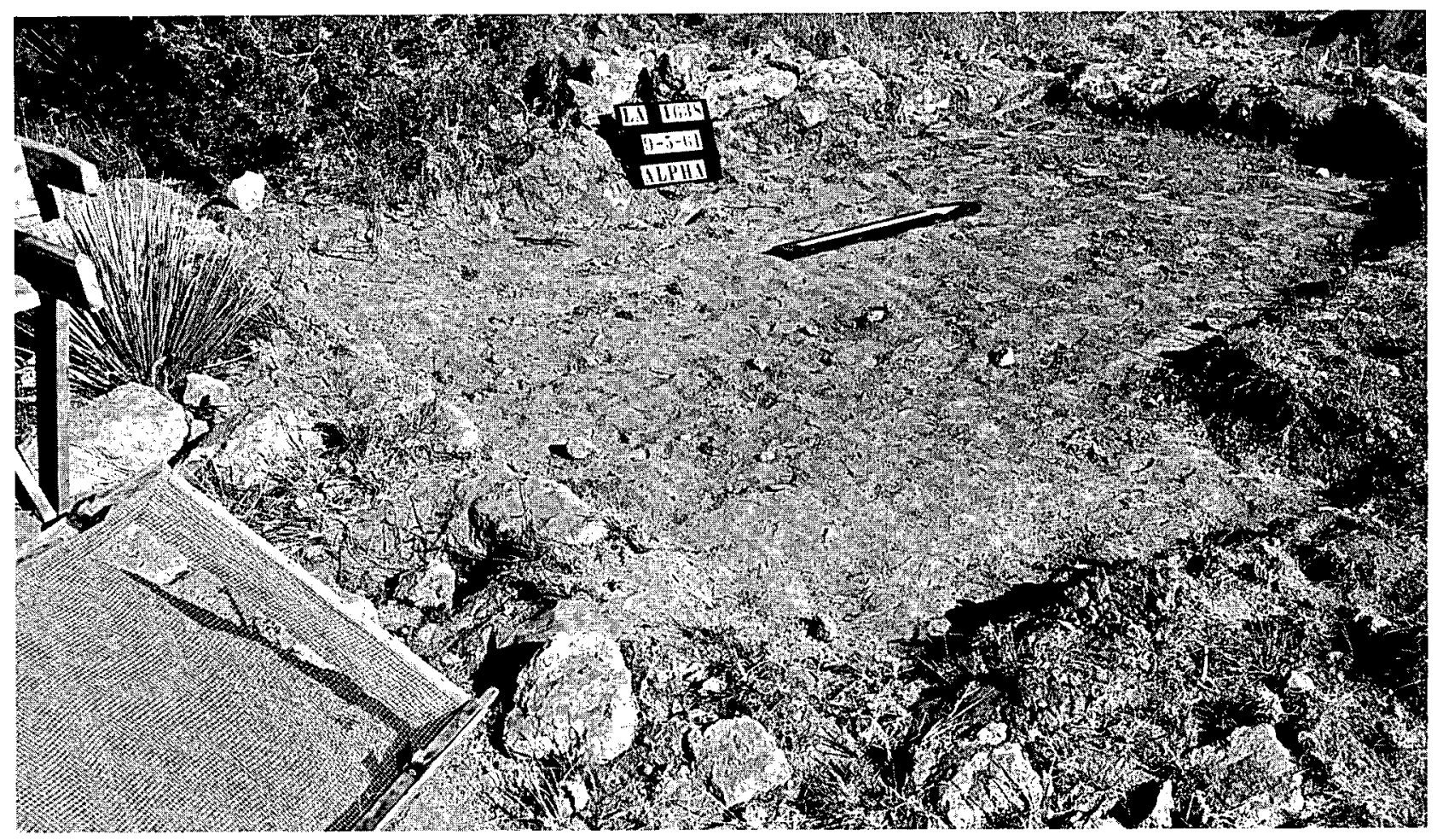

Fig. A-12.

LA 4638 after excavation. 


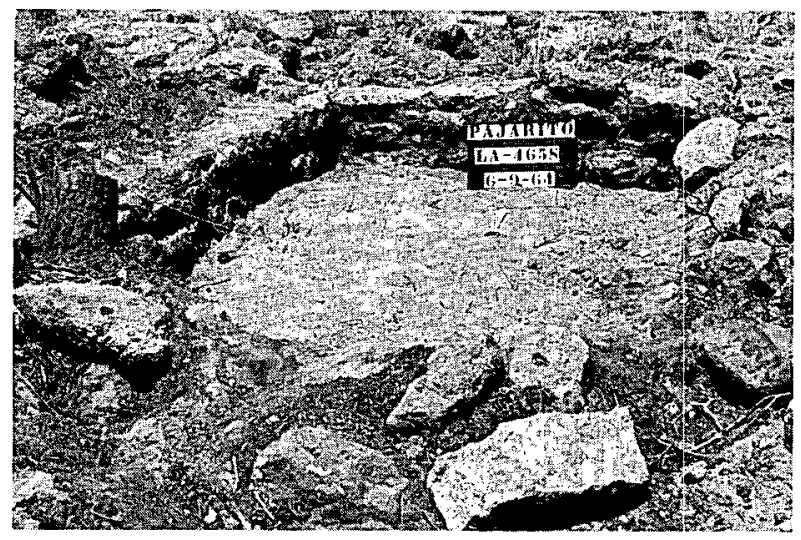

Fig. A-13.

LA 4658 after excavation.

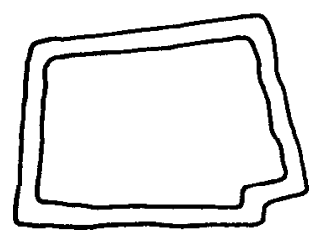

Fig. A-14.

LA 4658 (shown as LA 4659) on LASL drawing ENG-R 4449.
The ruin: This was a two-room site whose walls were indicated by tuff stones placed on edge probably indicating adobe walls. No other festures were noted or can be seen in photographs (Fig. A$20)$.

Pottery: None recorded.

Stone artifacts: None recorded.

Drawing: LASL ENG-R 4449, Fig. A-21.

\section{Site LA 4664}

Location: At the Betatron site in quadrant S7 E4 of the Los Alamos grid.

Excavated by: Charlie R. Steen, September 5, 1974.

The ruin: It is possible that the site had only two rooms; it was severely damaged by construction at the Betatron facility and, where the walls were found, only a single course of masonry remained.

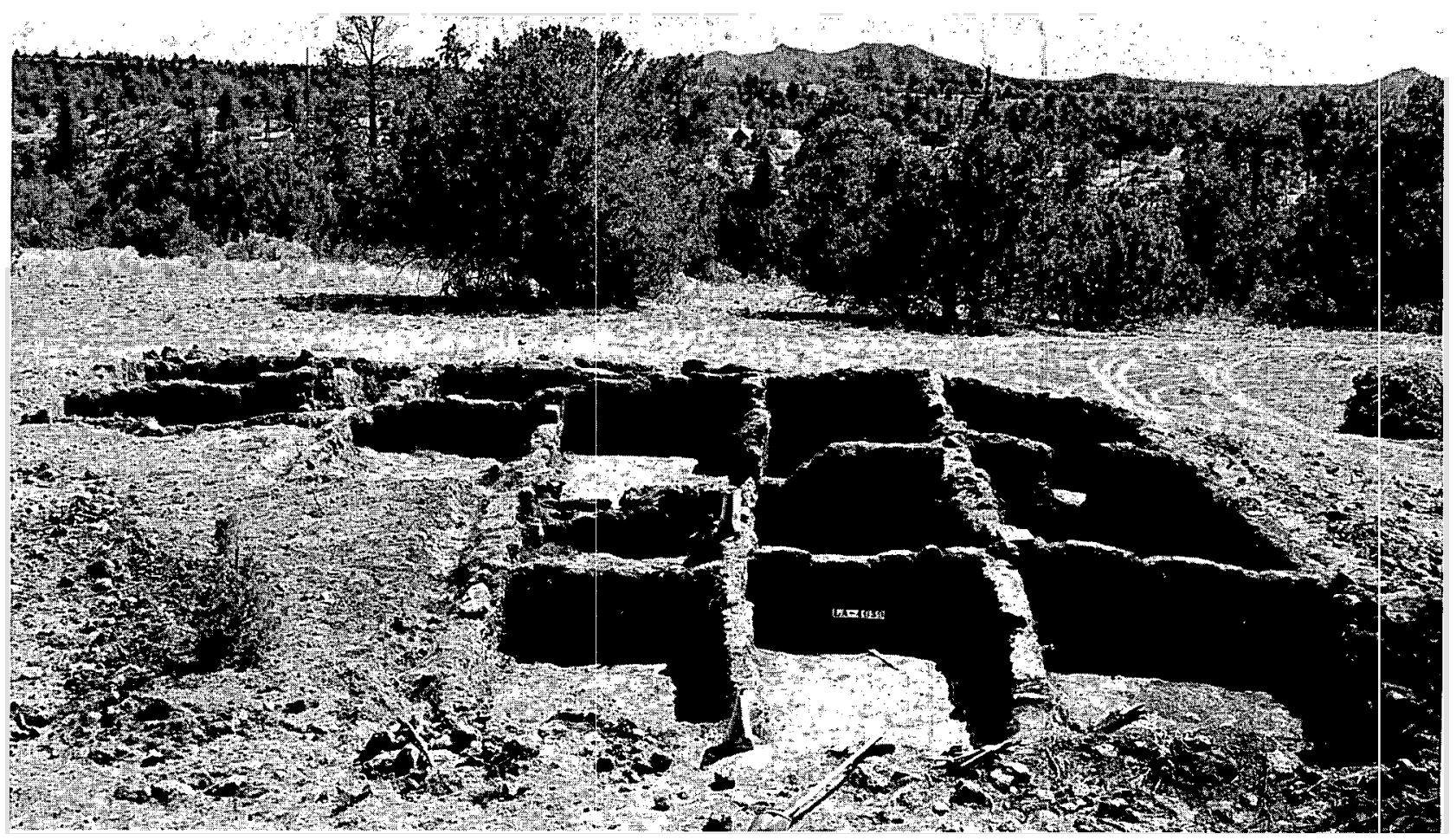

Fig. $A-15$.

A general view of LA 4659 from the east. 


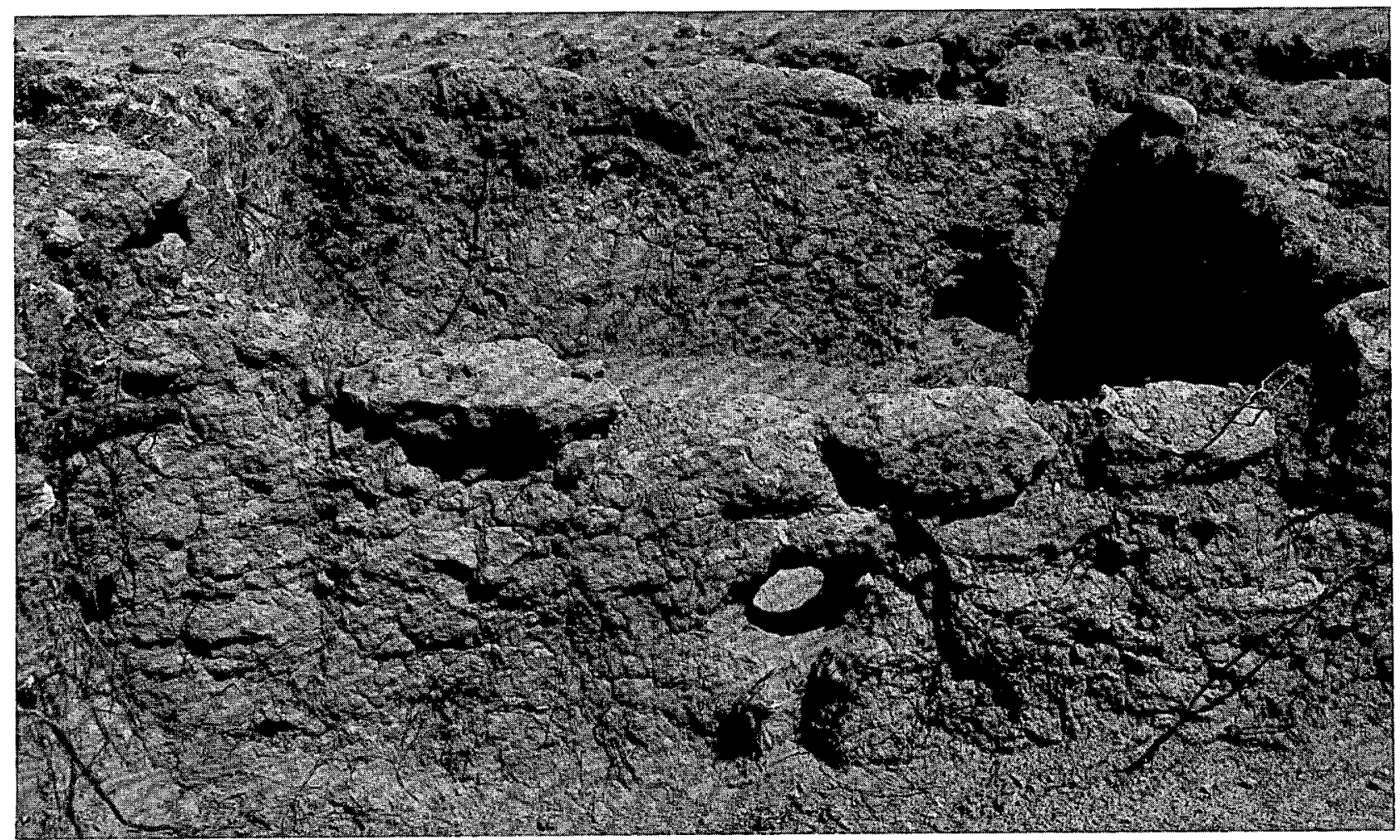

Fig. A-16.

Vent in wall of LA 4659.

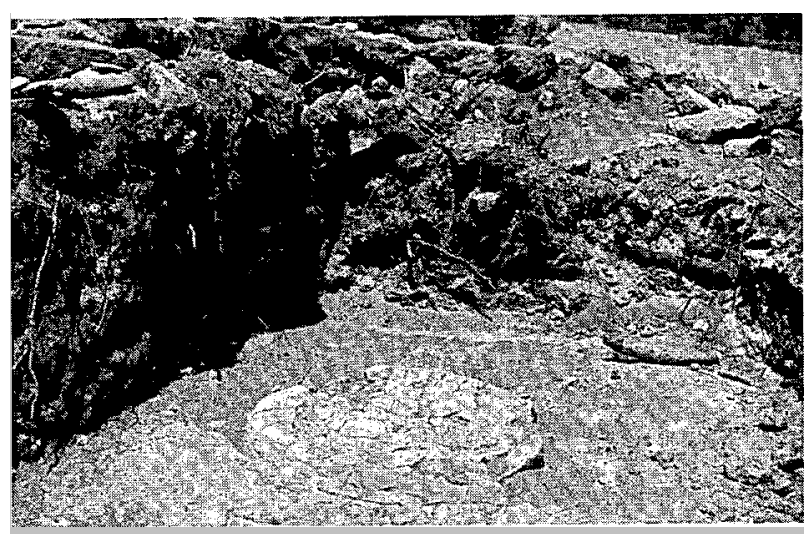

Fig. A-17.

The firepit in Room 10, emptied of ashes, filled with earth, and plastered with clay.

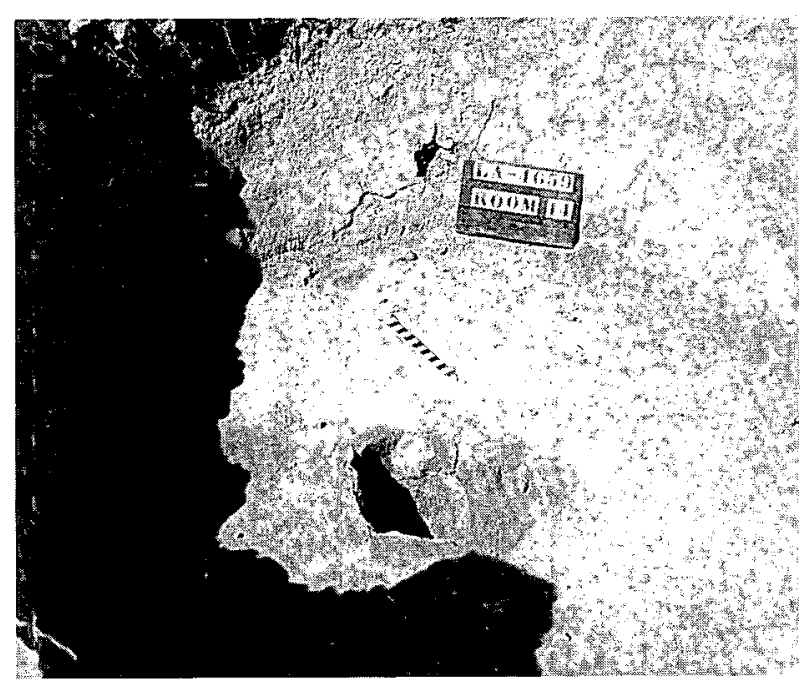

Fig. A-18.

The floor of the circular ceremonial room or kiva at LA 4659. 


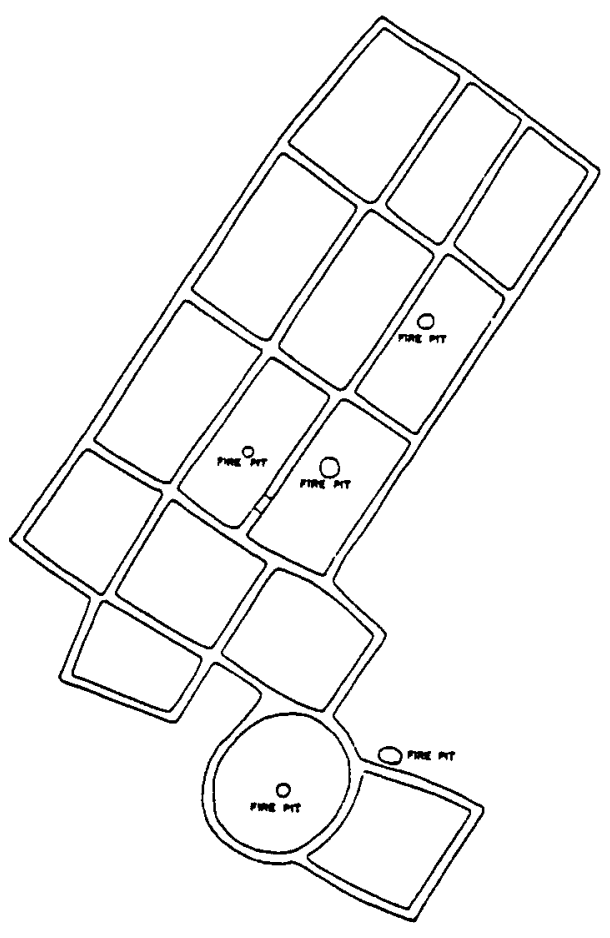

Fig. A-19.

LA 4659 (shown as LA 4658) on LASL drawing ENG-R 4448.

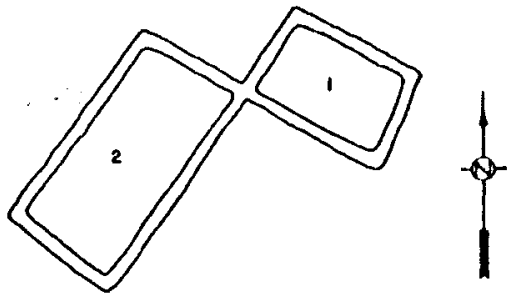

Fig. A-21.

$L A$ 4660, LASL drawing ENG-R 4449.

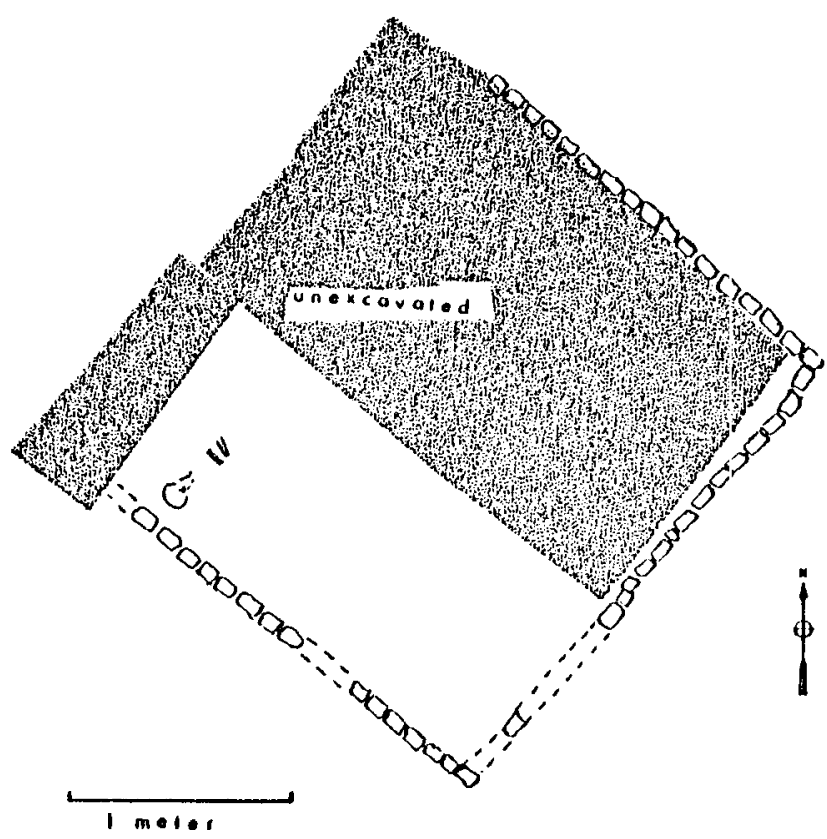

Fig. A-22.

LA 4664 excavation sketch showing position of burial.

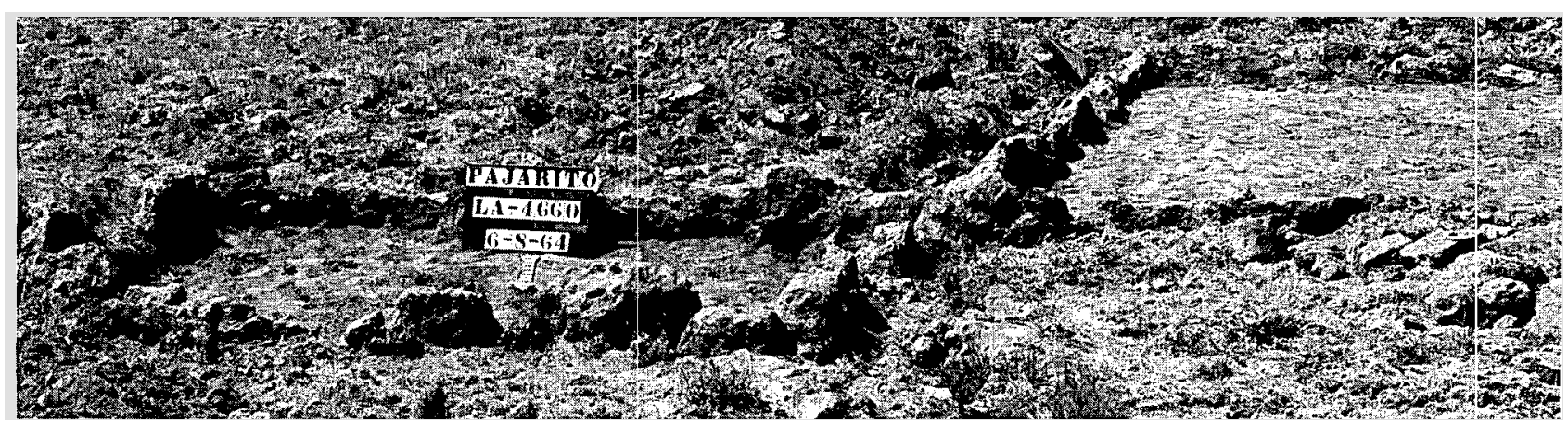

Fig. 20.

LA 4660 after excavation. 
Excavation was made here because, in early September 1974, an employee in TA-15 picked up some bones that proved to be frontal and facial bones of a human skull, probably of a young adult female.

The body apparently had been placed on or near the floor of an abandoned house, then covered with stones from the wall. The body was flexed with the head laid to the south, and no artifacts were found with it. Other than the bones originally found, the excavation uncovered only a few splintered long bones. Some piece of heavy equipment once plowed a furrow through the soil of the site and destroyed all other traces of the body.

Approximately one-fourth of the room was dug. The stones of the wall were only a single course high. On the east side of the room, the floor was found 15 $\mathrm{cm}$ below the surface. There was $30 \mathrm{~cm}$ of fill on the west side where the bones were found.

Pottery: Through some peculiar set of circumstances about one-quarter of the room was cleared without finding either a potsherd or a flake of stone.

Stone artifacts: Similarly, a search of the disturbed area surrounding the ruin produced no artifacts.

Drawing: Sketch made at time of excavation, Fig. A-22.

\section{Sites LA 4680 and LA 4686}

Location: Both sites are within TA-15; LA 4680 is in quadrant S5 E6 of the Los Alamos grid, and LA 4686 is in quadrant S5 E5.

Excavated by: Unknown persons within the recent past.

The ruins: LA 4680 was a one-room structure of large well-dressed stones. There is stone enough for only four or five courses. There is no entry into the "room" which is $2 \mathrm{~m}$ square.

LA 4686 is a similar one-room structure of large well-dressed stone, and it also has no entry. It is approximately 2 by $3 \mathrm{~m}$ in size. The south wall has fallen and shows the height of the wall - five courses.

Both were probably box-type shrines.

Pottery: None seen.
Stone artifacts: None seen.

Ground plan: None available.

\section{Site LA 4710 (DP East Site)}

Location: Within TA-21, at the site of the DP East building.

Excavated by: Frederick C. V. Worman during November 1963 and March 1964.

The ruin: An eleven-room structure whose rooms were arranged in two rows, aligned north-south (Figs. A-23, 24, and 25). Some walls were of adobe and some of masonry with large unshaped tuff blocks. A few walls were made of adobe to a height of $2 \mathrm{ft}$ and of masonry above that. Three rooms, all on the east side, had firepits. The firepits were round and more than a foot in diameter, and two had heavy adobe rims (Fig. A-26). One, without a rim, was apparently filled with earth and plastered over. Room 10, which is not shown on the sketched ground plan, had a storage pit in its southeast corner. The roof of room 11 had burned, and Worman thought the fire was caused by lightning.

Pottery: None recorded.

Stone artifacts: A heavy slab metate was found in room 2 .

Ground plan: A rough sketch from a Worman notebook is reproduced as Fig. A-27.

\section{Site LA 4722}

Location: The site is on Mesita de los Alamos near the ruins that Worman dug in 1967 (Worman and Steen). It has now been destroyed by construction at the Meson Facility.

Excavated by: Charlie R. Steen, June 5-18, 1974.

The ruin: LA 4722 was a seven-room structure (Fig. A-28) that was built, occupied, and then dismantled, all probably during the early 14 th century. It was a farmstead, typical of many contemporaneous settlements on the Pajarito Plateau. 


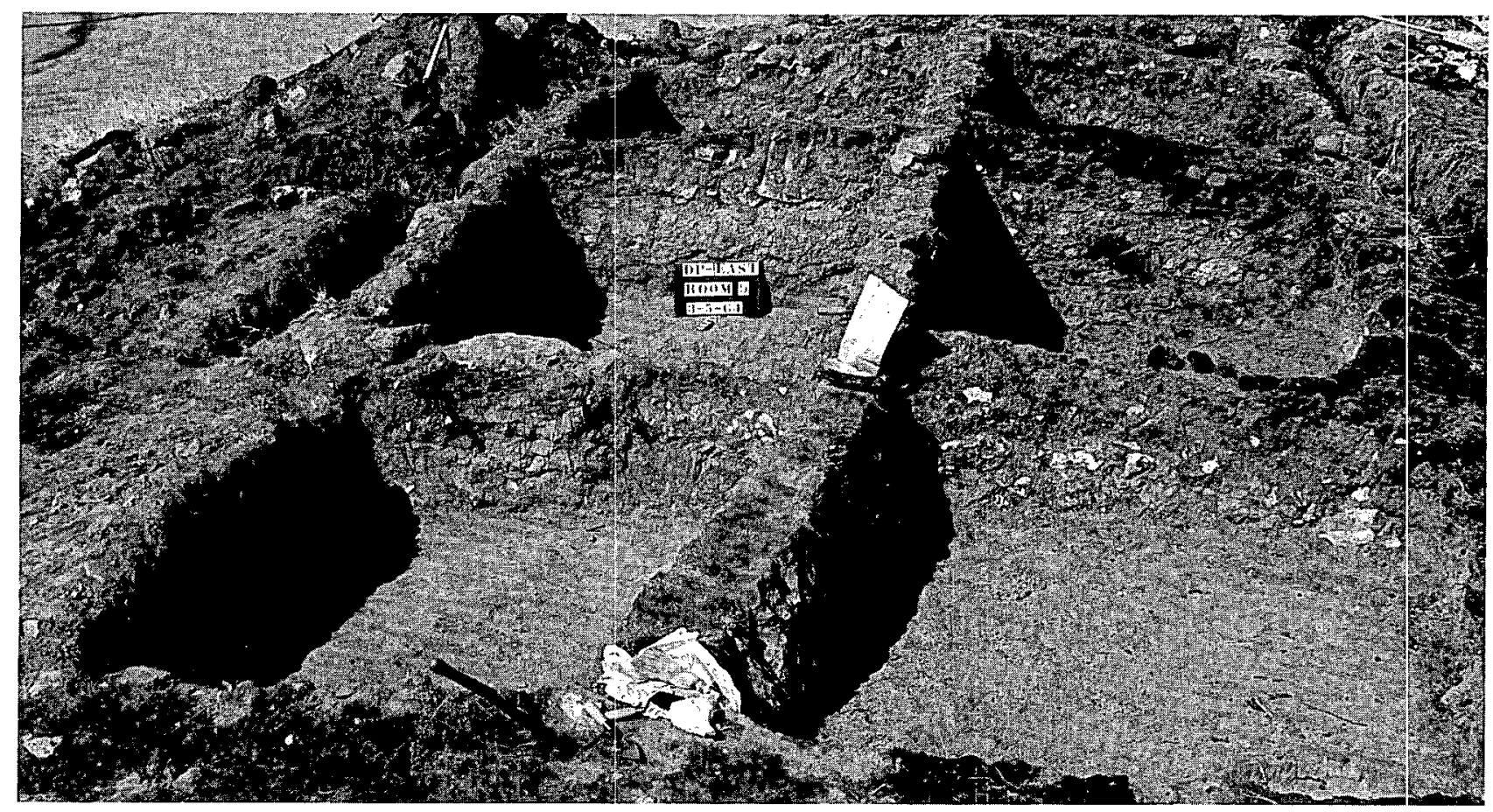

Fig. A-23.

A general view of LA-4710 after excavation.

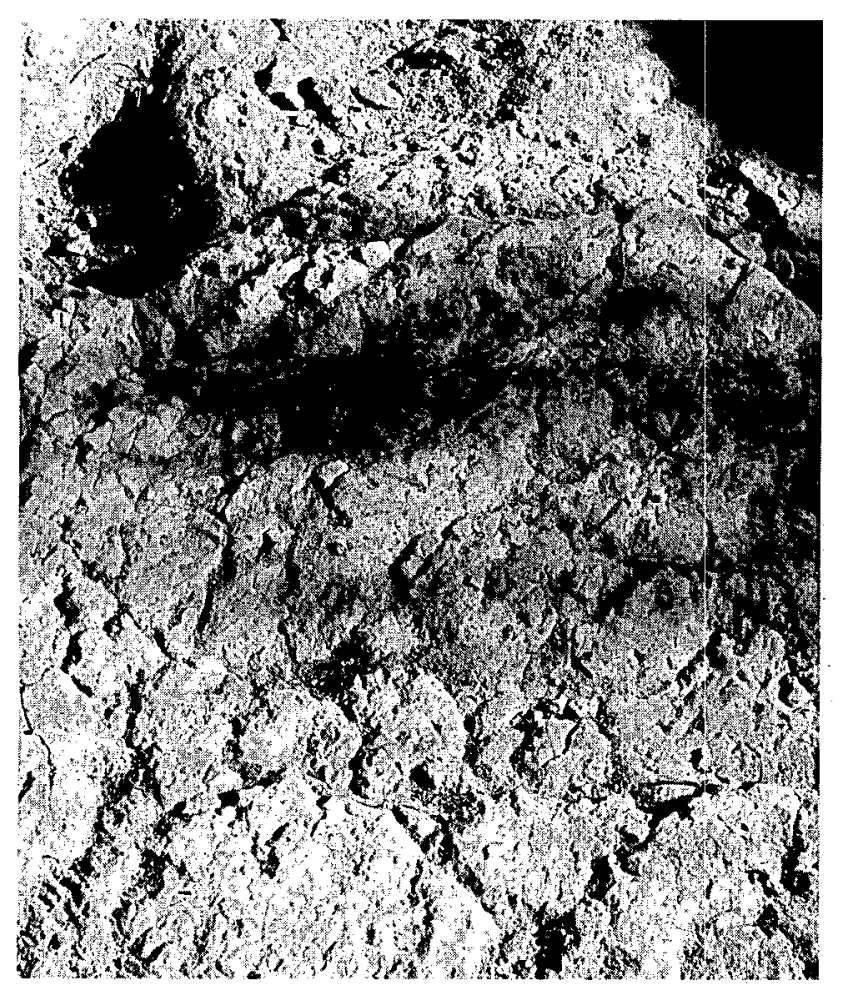

Fig. A-24.

A stone floor at LA 4710.

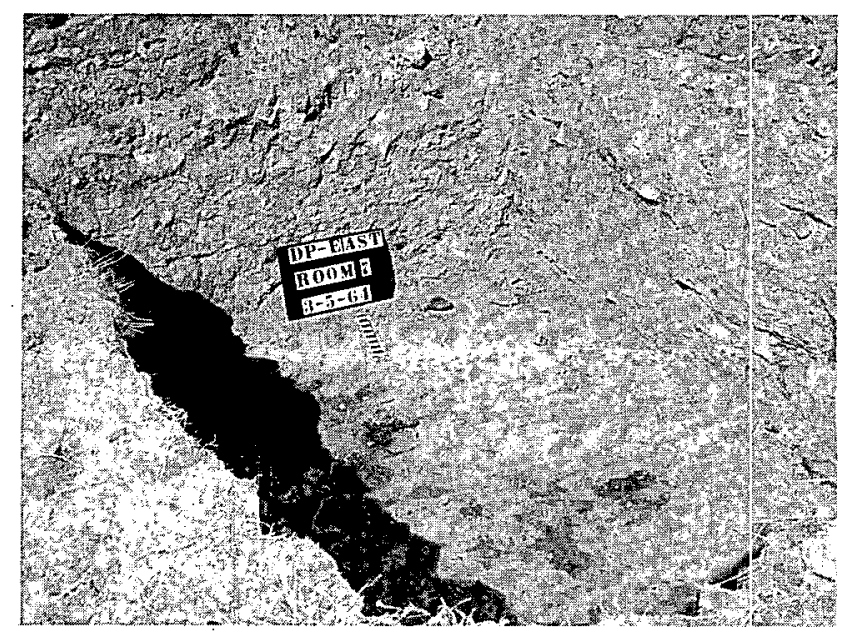

Fig. $A-25$.

The north wall of Room 7, LA 4710 had two thick courses of adobe, and the upper part was masonry. 


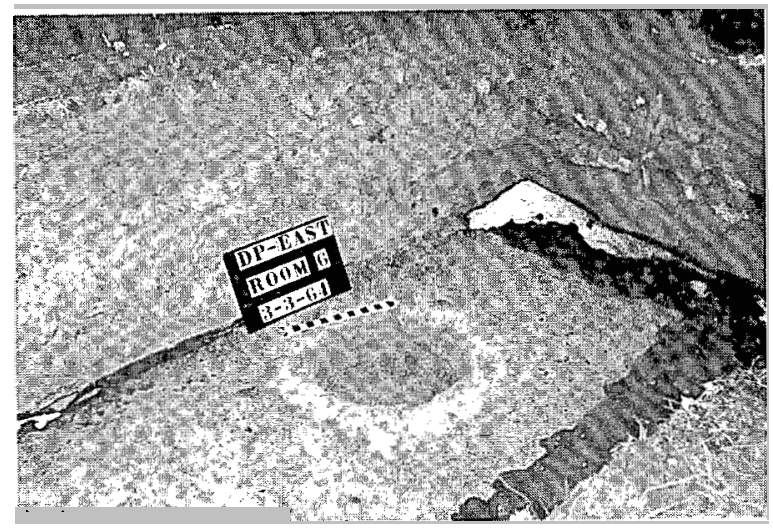

Fig. A-26.

$A$ deep firepit with a heavy adobe rim at $L A$ 4710 .

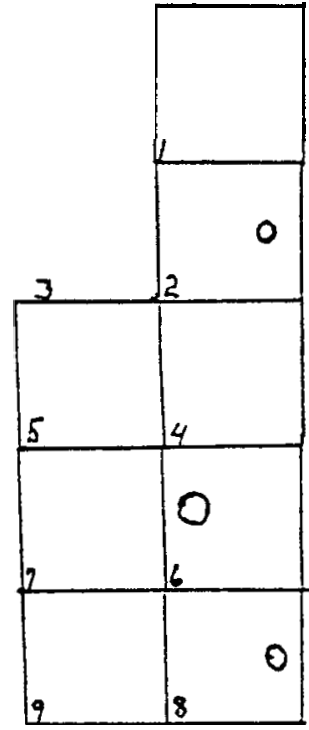

Fig. A-27.

Ground plan of Site LA 4710, the DP East Site.

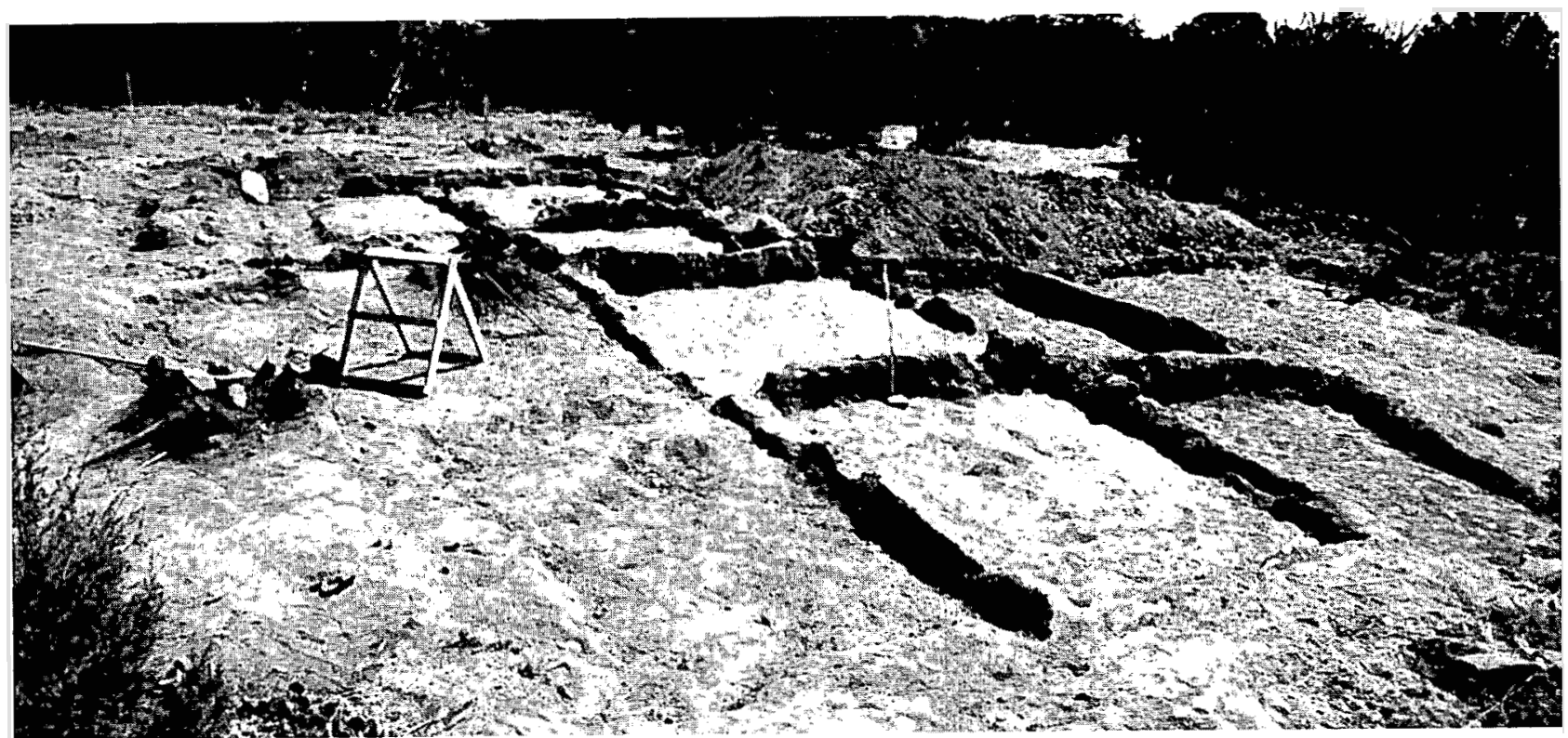

Fig. A-28.

A view of LA 4722, looking north. 
As we started to work, the site was a low mound with, at the northeast corner, a cairn of shaped tuff building stones. A shallow midden lay on the south and east sides of the house block; the walls of rooms 5 and 6 were laid on a thin lens of trash. East of rooms 5 and 6 , the midden was as much as $35 \mathrm{~cm}$ deep but it feathered out to only a centimeter or two within $3 \mathrm{~m}$ of the building.

Apparently, when they abandoned the site the Indians stripped the building of roofing materials and stone from the walls. No wall remained more than 40 $\mathrm{cm}$ high (two courses of stones). Few stones were found in the fill, which was composed largely of adobe, much of it in chunks. No roof beams were found.

All floors were so broken that they were found only in patches. Firepits were found in rooms 2 and 4 (Fig. A-29), and in rooms 1 and 3 there were accumulations of wood ash on the floors with no indication of burning. In room 2 there was also a shallow pit, not lined with clay, which contained a few stones. Some of the stones were fire-darkened.

The cairn. About $2 \mathrm{~m}$ northeast of the northeast corner of room 2 was a pile of approximately 50 tuff blocks, about half of which were shaped. We took the pile apart stone by stone, but found no pattern. It seems that, after the house block was abandoned, someone planned a small masonry shrine here but never got around to building it. There was stone enough for three or four courses of masonry if an enclosure of about 1 by $2 \mathrm{~m}$ had been built.

Pottery: Only a small amount of pottery was found at 4722 , and because the sherds from each room seem to fit the same pattern, all are tabulated together.

One shaped sherd of Santa Fe Black on White (Fig. A-30) was recovered from the fill of room 3.

\begin{tabular}{l} 
Painted Wares \\
\hline Santa Fe Black on White \\
without slip \\
with white slip \\
basket impressed \\
Wiyo Black on White \\
Wingate Black on Red
\end{tabular}

Corrugated

Micaceous gray

Micaceous buff

Basket impressed mica/buff

Plain gray

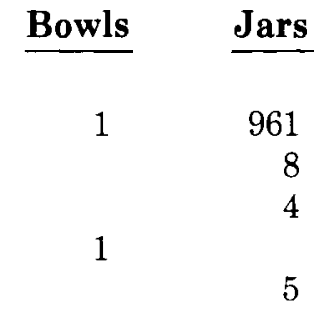

Stone: A few undistinctive stone tools, choppers, hammer stones, knives, and scrapers (Fig. A-31) were taken from the fill of the rooms. The knives and scrapers were uniformly fashioned of traprock, and the hammerstones were of Pedernales chert. Two projectile points (Fig. A-32) were made of obsidian.

A large slab of rhyolite tuff (Fig. A-33) identified by William D. Purtymun, was probably a cover for a hatch or doorway.

Bone: A single bone awl (Fig. A-34) was made from a long bone of a rather large animal - probably a deer.

Shell: A fragment of irridescent shell, from a bivalve, was found on the floor of room 1 .

Ground plan: Fig. A-35.

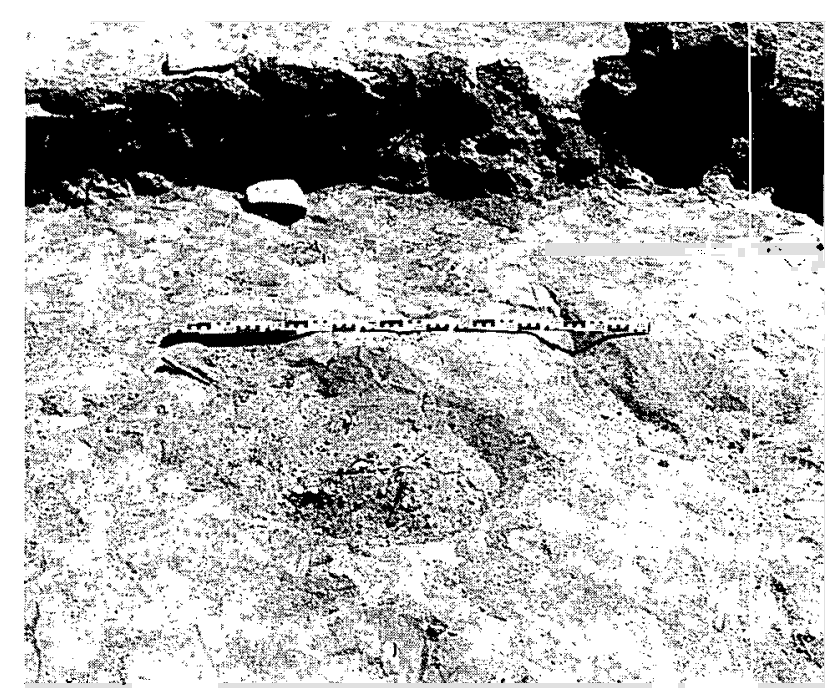

Fig. A-29.

The remains of a firepit in Room 2 of LA 4722 . 


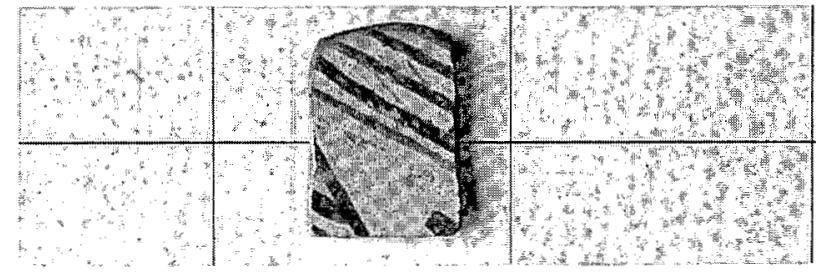

Fig. A-30.

A shaped Santa Fe Black on White sherd from LA 4722 photographed against a $5-\mathrm{cm}$ grid.

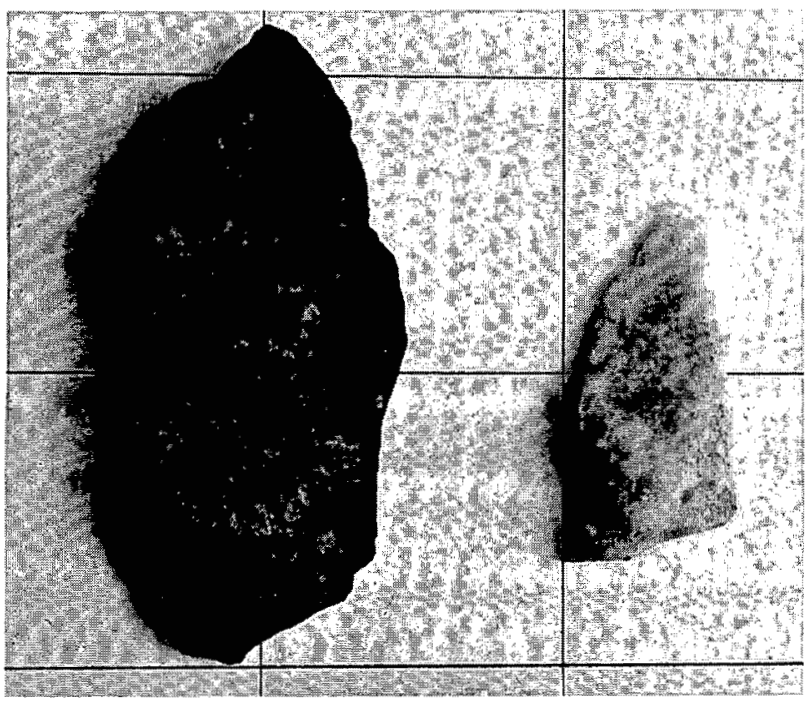

Fig. A-31.

Rough tools made of a traprock flake (left) and Pedernal chert (right) from LA 4722 . Photographed against 5-cm grid.

\section{Site LA $\mathbf{4 7 2 8}$}

Location: On Mesita del Buey, in the Pajarito Road construction zone.

Excavated by: Frederick C. V. Worman, in June 1964.

The ruin: This was a one-room structure. Worman considered it to be a summer shelter or ramada.

Pottery: None found.

Stone artifacts: None found.

Ground plan: Shown by ENG-R 4449, Fig. A-36.

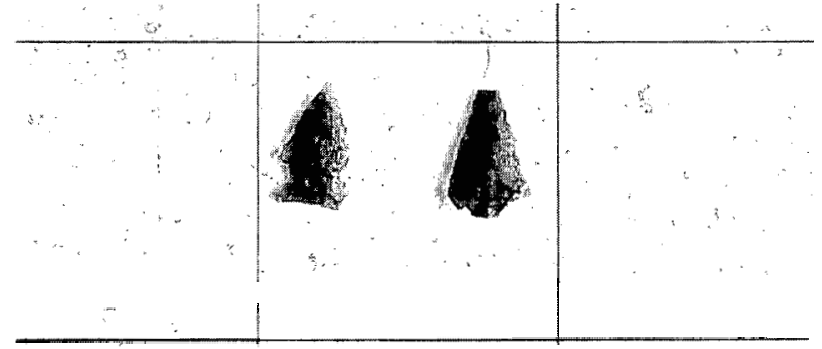

Fig. A-32.

Obsidian arrow points from $L A 4722$, against a 5-cm grid.

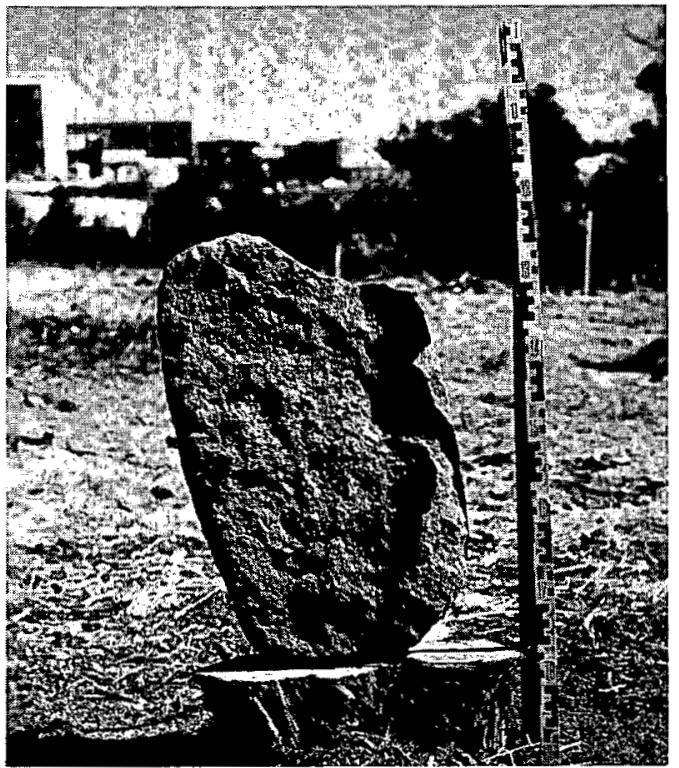

Fig. A-33.

This large slab of stone, which must have been a hatch cover, was found on the floor of Room 2, LA 4722.

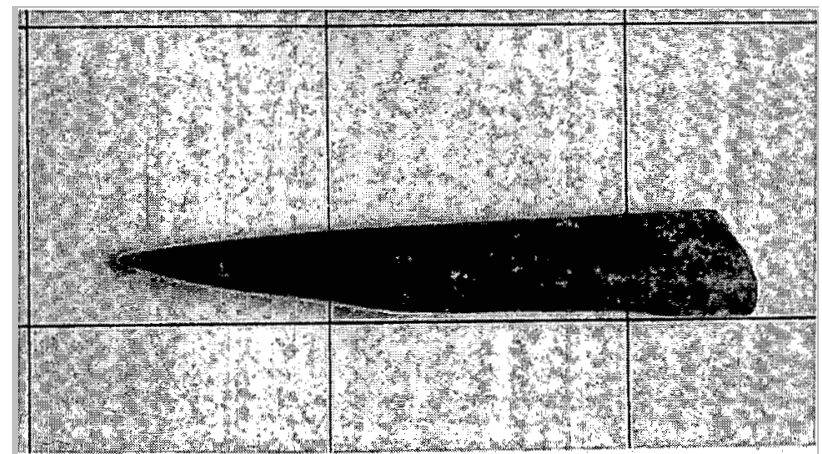

Fig. A-34.

Bone awl from LA 4722 


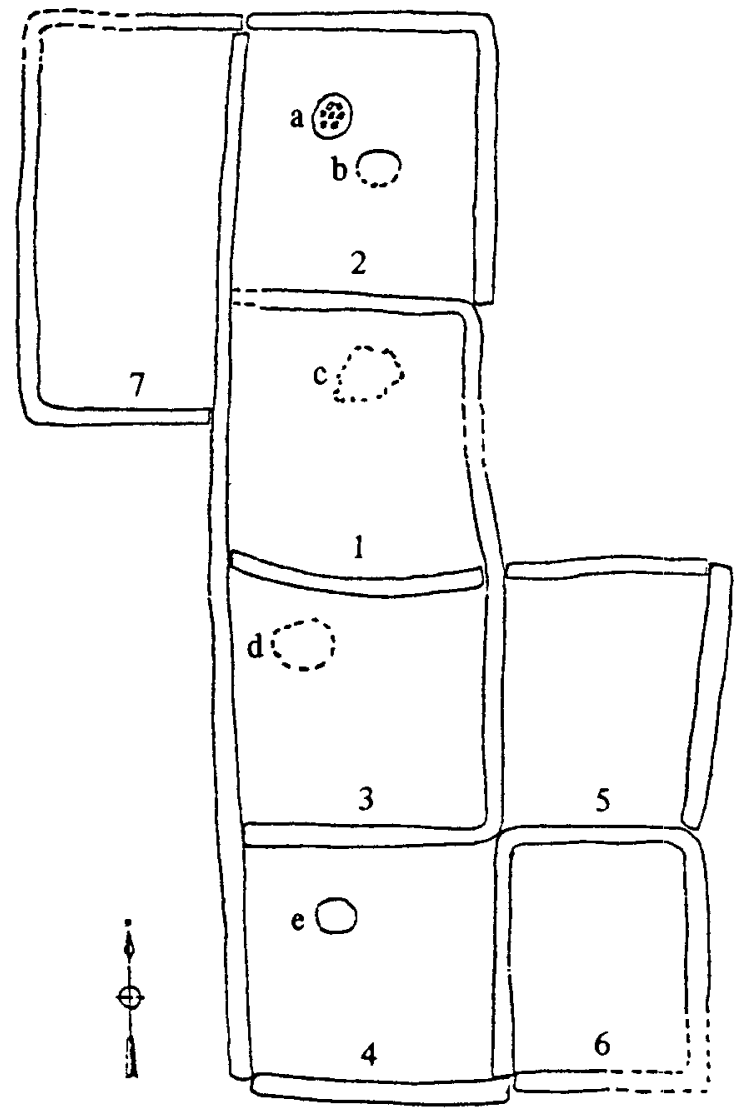

a: Shallow pit with small stones.

b: Fire pit.

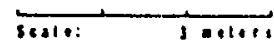

c: Concentration of wood ash.

d: Concentration of wood ash.

e: Fire pit.

Fig. A-35.

LA 4722 ground plan.
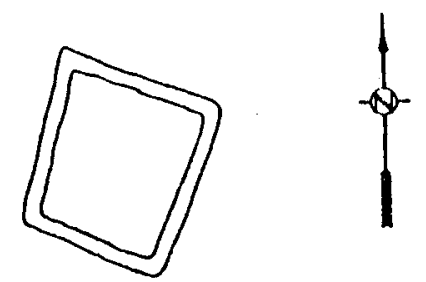

Fig. A-36.

LA 4728 as shown on LASL drawing ENG-R4449 .
Site 8681 (Fulton 190)

Location: Within the Pajarito Acres subdivision of White Rock Community.

Excavated by: Los Alamos Archaeological Society in 1953-1956.

The ruin: This was a masonry pueblo of 21 rooms and a kiva, with one isolated room nearby. Two manuscript reports by Fretwell $(1954,1959)$ and a summation by Maxon (1969) were prepared. Several tree ring dates, none of them cutting dates, were obtained from beam specimens in the ruin. They range from A.D. 1167 to 1264 and are reported in Young (1954) and Robinson et al. (1972).

Pottery: Kwahe'e Black on White

Santa Fe Black on White

Wiyo Black on White

Galisteo Black on White

Abiquiu Black on Gray

Bandelier Black on Gray

Agua Fria Glaze on Red

Puerco Black on Red

Wingate Black on Red

Tesuque smeared indented

Cordova micaceous ribbed

Cundiyo micaceous indented

Micaceous plain ware

Stone artifacts: A small collection of stone artifacts, typical of the upper Rio Grande, and of the Pajarito Plateau, was recovered and is described in Fretwell (1959) and Maxon (op. cit.).

Ground plan: None available.

\section{Site LA 12609}

Location: The site consists of approximately 50 cavate rooms strung along a half mile of the north side of Mortandad Canyon, and a plaza site on top of the mesa. This was formerly within Bandelier National Monument and was listed as Site No. 51 in the National Park Service Survey. The wellpreserved cave kiva at the site was excavated by James Maxon of the Monument staff, and part of his 
report is reproduced here. This site is also discussed further in Section III.L.2 in the body of this report. LA 12609 is in quadrant N2 E13 of the Los Alamos grid.

Excavated by: James C. Maxon, November 1962.

The ruin:

"The cave that was cleared was the largest and best preserved of the group and was apparently a kiva. It is quite similar to the cave kivas in Frijoles Canyon which are described by Hewett (1909, pp. 660-663). The cave measures about $10 \mathrm{ft}$ by $12 \mathrm{ft}$. (See Fig. A-37.) The long axis of the room parallels the cliff face, which runs in a general northwestsoutheast direction. There are two entrances into the cave. (See Fig. A-38.) The west door opens into the southwest corner of the kiva and measures approximately 16 in. in width and 37 in. in height. The east door is 25 in. from the west door. It is rather unusual in shape, having an offset near the top of the east jamb. It is 21 in. wide above the offset, 34 in. wide below and 46 in. high. Both doors had been blocked with rocks in recent years.

There are 4 niches in recesses in the kiva walls. Recess $A$ is located at floor level in the west wall near the west door. It is round in shape. The opening is approximately $20 \mathrm{in}$. in diam and it is 20 in. deep.

Recess $B$ is in the north wall. It is roughly rectangular in shape; being approximately 29 in. long, $15 \mathrm{in}$. deep and $11 \mathrm{in.} \mathrm{high.}$

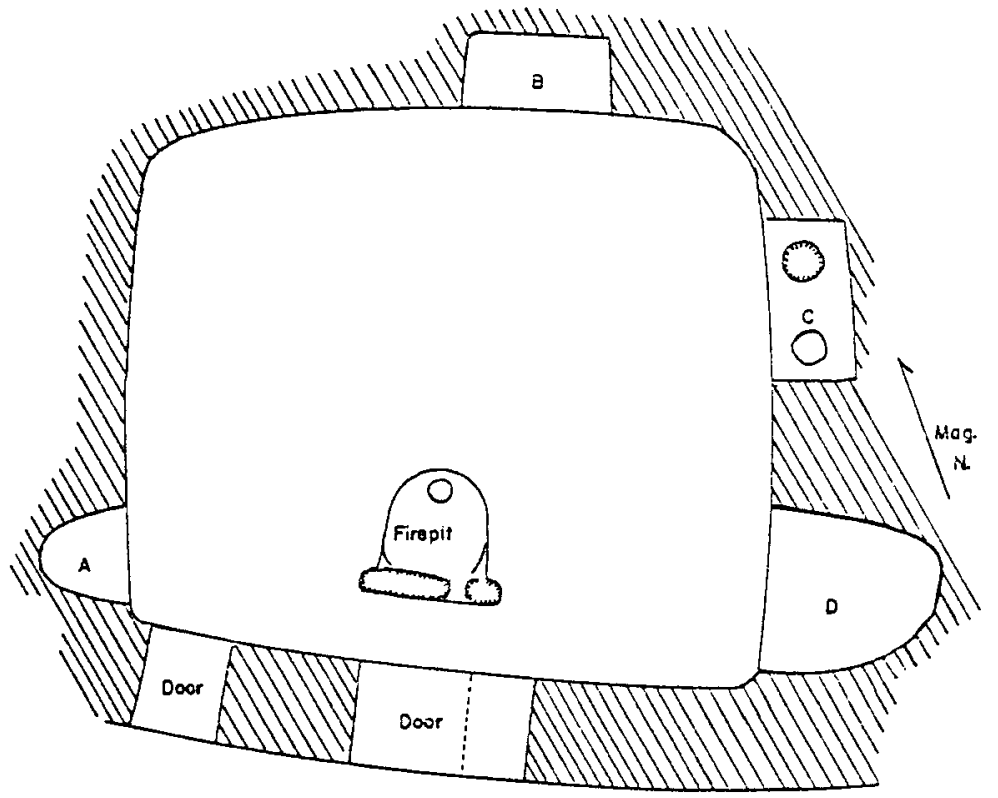

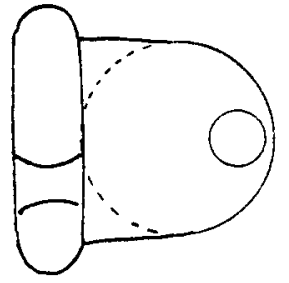

A. Top view of firepit.

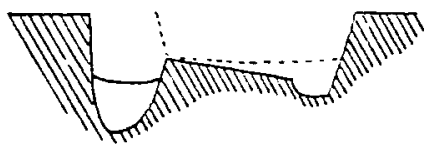

B. Cross section of firepit.

Fig. A-37.

Cave kiva at LA 12609. 


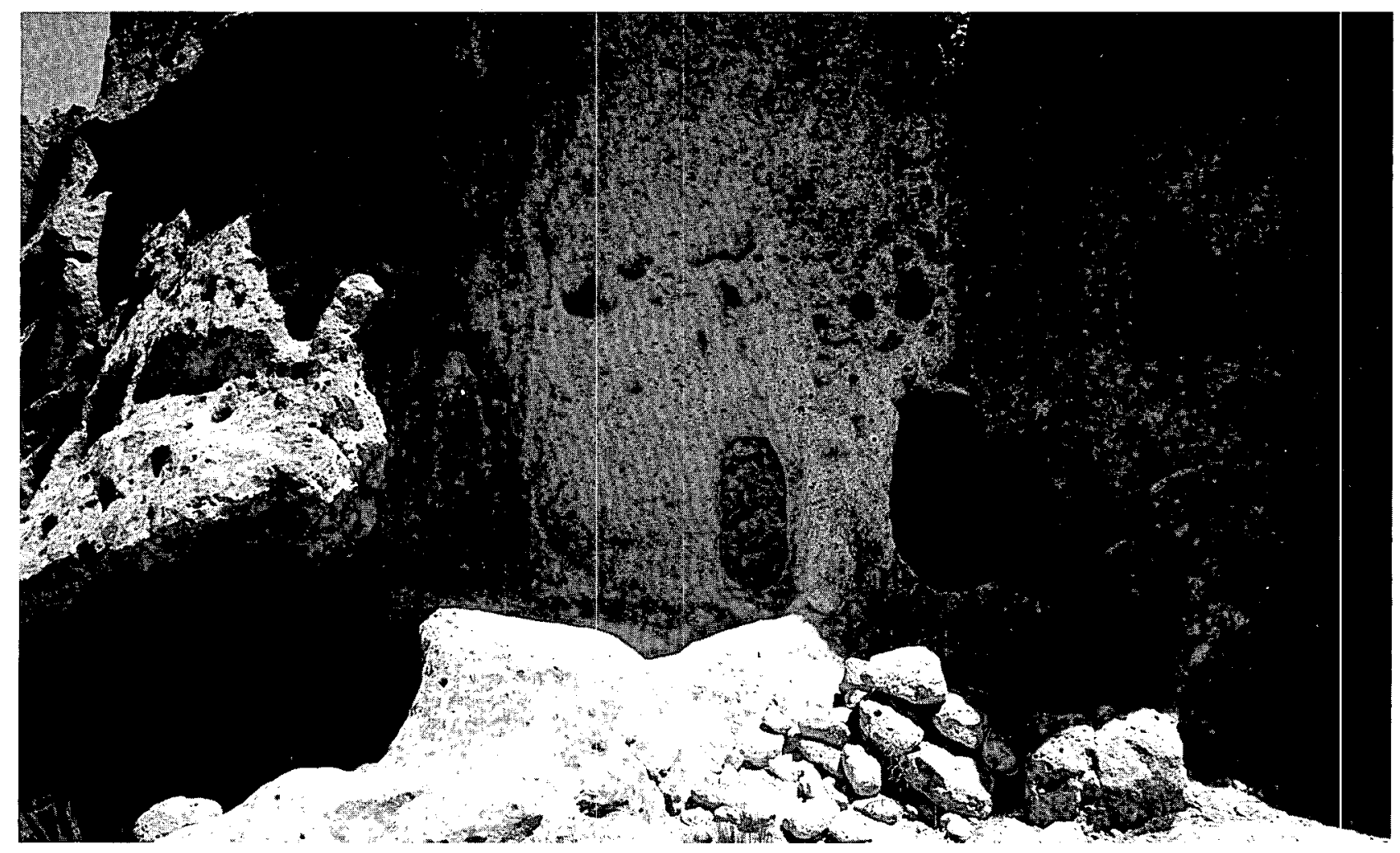

Fig. A-38.

Outside of cave kiva at LA 12609.

Recess $C$ is in the east wall near the northeast corner of the kiva. It is also rectangular in shape, measuring 31 in. wide, 16 in. deep, and 28 in. high. Two petroglyphs representing animals are carved on the back wall of the recess. There are two depressions on the floor of the recess which were apparently used for mealing purposes. The depression to the left is a shallow basin which probably was a mortar. The other depression is bowl-shaped and may have served as a receptacle for whatever was ground on the mortar.

Recess $D$ is located in the southeast corner of the kiva. It is approximately 32 in. wide, 31 in. high and 33 in. deep. The recess had long been: a packrat nest and the upper fill was composed of a typical collection of twigs, leaves, yucca leaves, and other plant material. Several small corn cobs and husks, which are no doubt prehistoric, were found in the lower fill of the recess. A 2 to 5 in. thick layer of extremely fine wind-deposited dust covered the floor of the cave. The floor of the cave had been plastered with four successive coats of soot-blackened clay. Approximately half of the floor plaster remains. The only objects found on the floor were a bit of charcoal and a small flake of obsidian.

An unusual firepit had been cut into the tuff floor of the cave. In its original form it was circular and clay lined; being about 19 in. in diain and 5 in. deep. The firepit was remodeled by enlarging it to its present irregular form. The purpose of the two projections on the south and the small secondary pit in the north side of the pit is unknown.

The fill of the firepit consisted of earth, a few bits of charcoal and two potsherds. Two small holes in the floor near the northeast corner of the kiva may have been loom anchors. No other holes were found; however, no plaster remained where the others may have been. 
The interior of the cave is elaborately decorated with a series of bold, well-executed petroglyphs carved into the soot-blackened ceiling and walls. A dado of tan plaster extends from the floor to a height of approximately 30 in. above the floor. Figures represented by the petroglyphs include the hunchbacked flute player, the plumed serpent, masked dancing figures, birds and other animals. Apparently either there were few fires in the kiva after the figures were carved, or they were periodically cleaned, as the incised areas have little or no soot remaining in them.

Almost no cultural material was recovered from the cave. Five small corn cobs, a corn cob stem, and some corn husks were found in Recess $D$, along with other material which apparently was of recent origin. The cobs average about 5/8 in. in diam, 3 to 4 in. long and had 10 or 12 rows of small kernels. Also, a good many dried leaves of the narrow leaf yucca were in Recess D. These may or may not be prehistoric.

The obsidian flake found on the floor was the only stone object found. It had some secondary flaking and may have served as a scraper.

John Turney (1955, p. 46) secured a surface collection from Site 51 which contained the following pottery types:

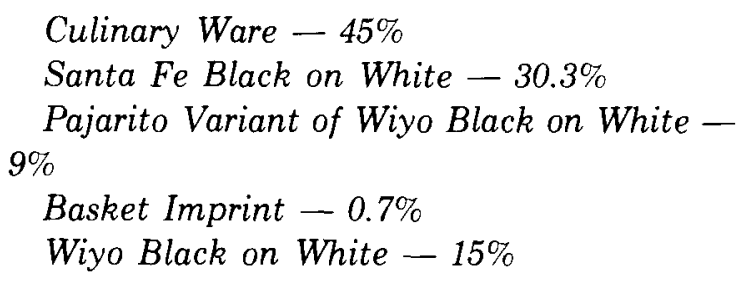

This information would suggest that Site 51 was occupied sometime during the first quarter of the 14th century..."

\section{Site LA 12743}

Location: On the north face of Pajarito Canyon. This site extends for about a quarter mile east from the junction with Three Mile Canyon.

Excavated by: Frederick C. V. Worman, in 1964.
The ruin: There are approximately 50 cavate rooms and an undetermined number of surface rooms along this section of Pajarito Canyon. In 1964, Worman dug six cavate rooms and six surface rooms at the spot where Pajarito Road drops into the canyon; construction of the road subsequently destroyed these rooms. Two of the cavate rooms dug had sets of loom holes, and one had a small hole ( 2 in. diam and 2 in. deep) that was filled with ochre.

Pottery: None recorded.

\section{Site LA 13286}

Location: The site was near the eastern end of Three Mile Mesa, above the breaks into Three Mile Canyon. It was in quadrant S4 E6 of the Los Alamos grid.

Excavated by: Charlie R. Steen, January 26-27, 1976.

The ruin: As it was found, the site consisted of a small, low cairn some of whose stones were shaped. It looked like, and proved to be, a box shrine.

On excavation, it was a squarish chamber whose walls were not aligned to the cardinal points. The builder dug a shallow pit $0.25-0.35 \mathrm{~m}$ deep and roughly $1.5 \mathrm{~m}$ to a side. On the southwest side, he laid a wall in which were a number of shaped stones. This wall was laid on the floor of the pit - the other three walls of the square were laid on the rim of the pit and none of the stones in place was shaped. The floor of this miniature room was probably of hardpacked soil, but not plastered. There was no indication of plaster on the low earthen walls. In the eastern corner of the room there might have been a low cube of adobe - an altar?

At the time of excavation, the southwest wall stood three courses high; one course was above ground level. The short section of wall on the southeast side was two courses high, but all other wall parts were only a single course.

Pottery: Two sherds were found. In the fill of the room, above the floor, was a sherd of plain ware of micaceous clay. The coils of the vessel wall were rubbed and partially obliterated. On the ground surface, $2 \mathrm{~m}$ from the room, was a single sherd of Largo 
Glaze on yellow (Hawley 1936). The nearest habitation site, LA 4684, which is more than $100 \mathrm{~m}$ distant, yields Santa $\mathrm{Fe}$ and Wiyo Black on White.

Stone: One flake of Pedernal chert was recovered from the fill in the room.

Ground plan: Fig. A-39.

\section{Site: R Site No. 1}

Location: No location was given for this site, but the designation "R Site" and ponderosa pines in photographs indicate that it was in TA-15 and on the mesa between the upper reaches of Pajarito and Water Canyons. (One note says the site was at Barricade $\mathrm{R}$ 93.)

Excavated by: Frederick C. V. Worman in August 1959.
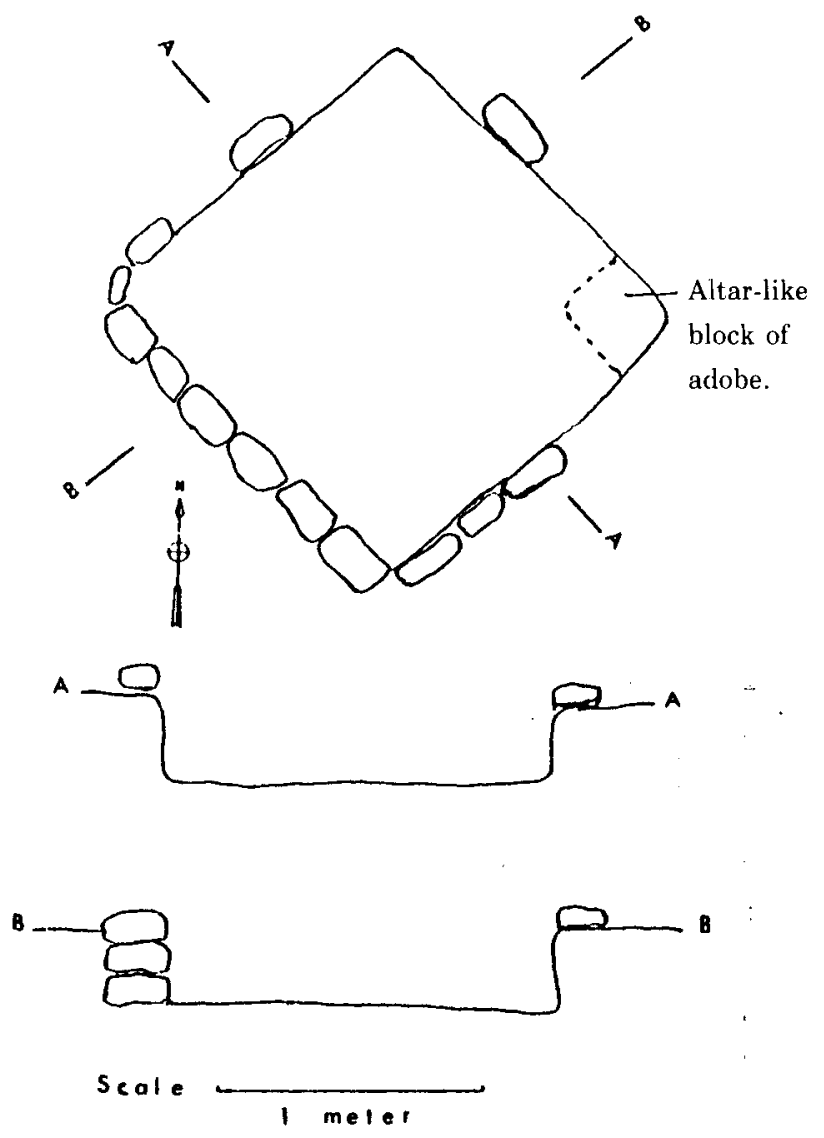

Fig. A-39.

Ground plan and profiles of LA 13286.
The ruin: The site had 11 rooms, 10 of which were in a double row aligned north-south (Fig. A-40). The other room was near the northeast corner, separated from the main house block. The walls were of adobe. An unusual feature of the walls was use of finely shaped tuff blocks to serve as basal stones in at least two rooms. One room has a floor of stone slabs, which, from the photo (Fig. A-41), seem to have been tuff. There was no firepit in this room. There were firepits in only three rooms $-2,3$, and 6 , which were contiguous rooms on the east side of the pueblo. Rooms 2, 3, 6, and 7 had well-laid adobe floors. There was no evidence of passageways or openings between the rooms. The firepits were all round in plan, more than $1 \mathrm{ft}$ in diameter, and about $1 \mathrm{ft}$ deep. They were clay lined, and none had a raised rim. At least one had been filled and then plastered over.

Pottery: There is no record of the pottery recovered, but a few sherds of what is probably Santa Fe Black on White appear in one photo.

Stone artifacts: Three slab metates and two twohand manos were photographed.

Drawing: The site listed as LA 4668 in drawing ENG-R 4450 is probably R Site No. 1 (Fig. A.42). The plan agrees well with a very rough sketch of an "R Site No. 1" in a Worman notebook and is presented here as being of this site. (LA 4668 in the Worman survey is a three-room unexcavated site in the cluster of ruins near the PHERMEX facility.)

\section{Site: R Site No. 2}

Location: The site was probably within TA-15, on the mesa between the upper ends of Pajarito and Water Canyons.

Excavated by: Frederick C. V. Worman, in August 1959.

The ruin: This was a four-room structure with adobe walls (Fig. A-43). Two rooms had firepits, about which not much can be told, except that they were round and deep.

Pottery: None recorded. 


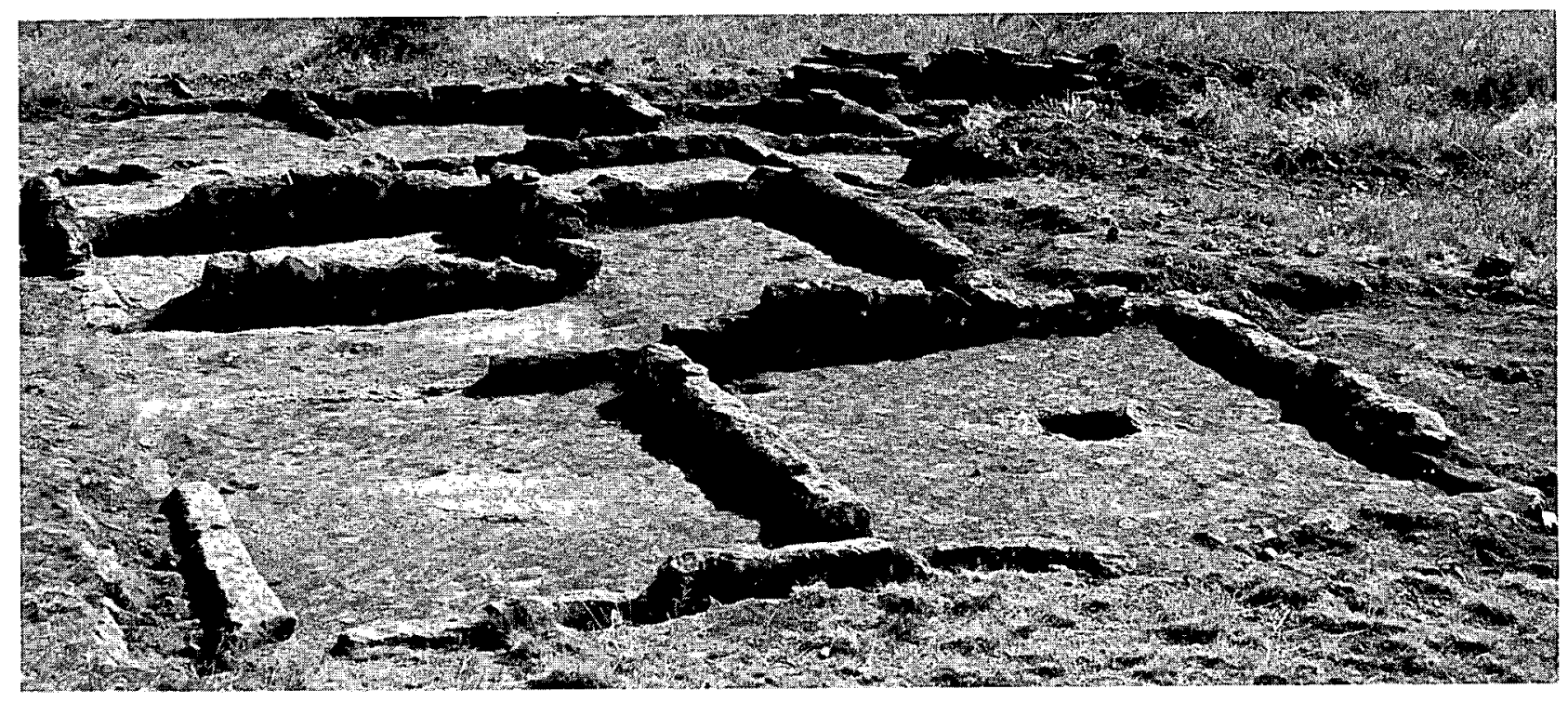

Fig. $A-40$.

A general view of $R$ Site No. 1 after excavation.

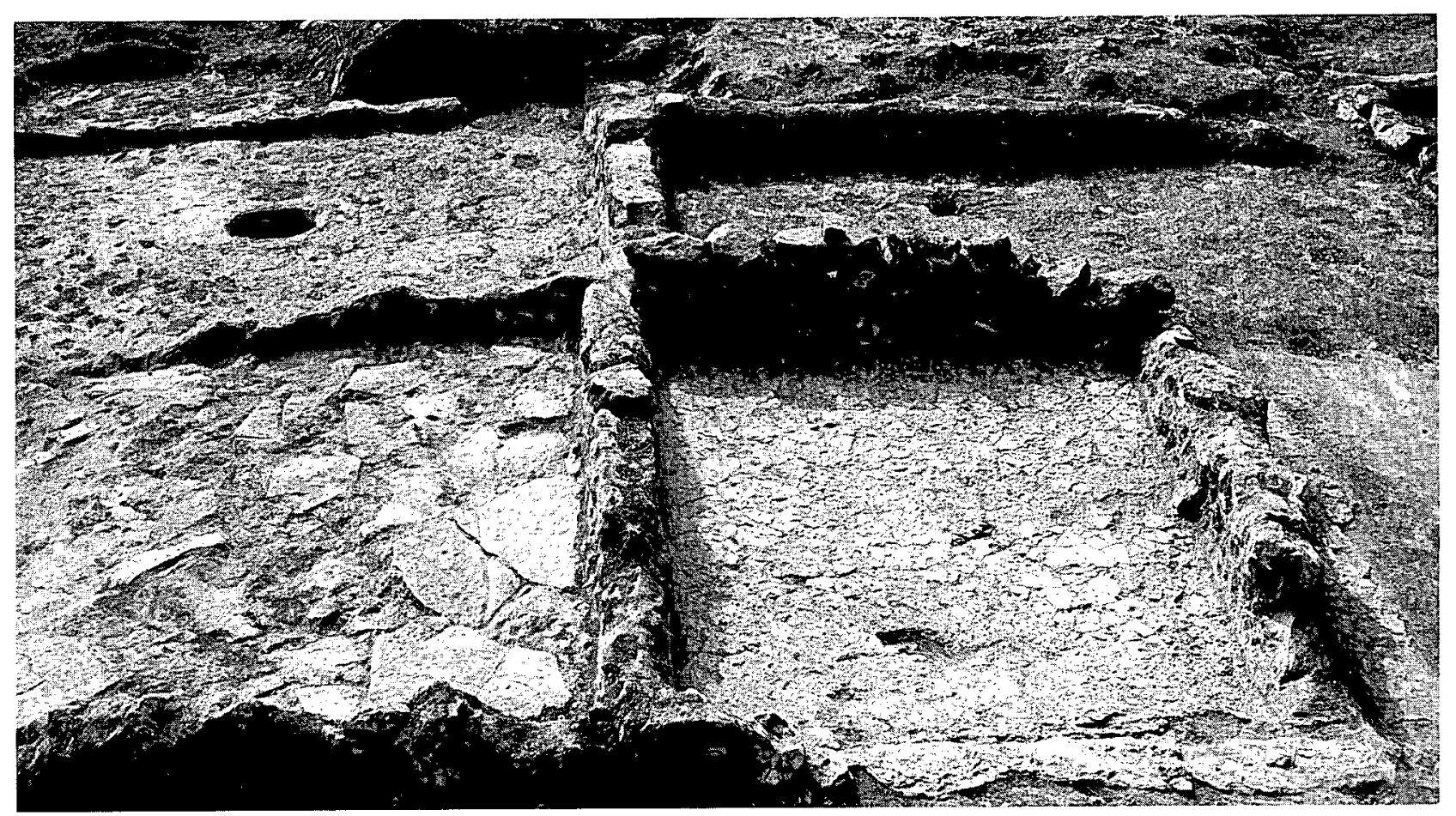

Fig. A-41.

$R$ Site No. 1, showing in upper left a deep circular firepit and in the foreground a stone slab floor and a well-laid adobe floor. 


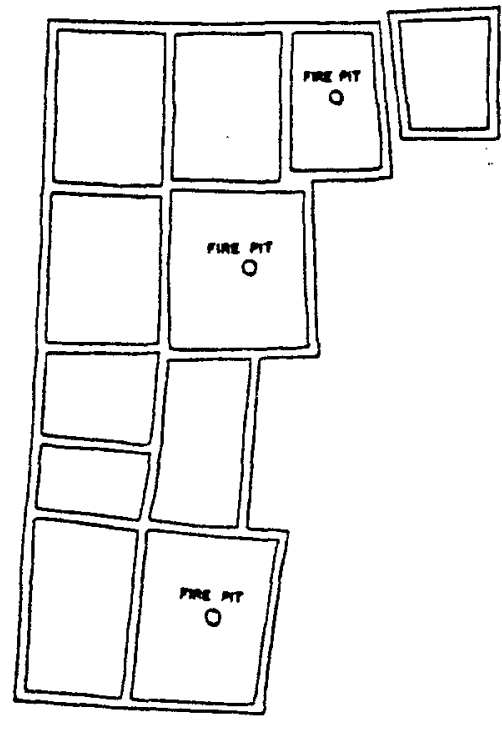

Fig. A-42.

Indian ruin $R$ Site No. 1, LA 4668.

Stone artifacts: None recorded.

Drawing: The site listed as "Indian ruin No. 2, LA 4666 " in ENG-R 4450 is probably this ruin (Fig. A44). On Worman's survey maps, LA 4666 is the number given to the unexcavated site southwest of the M-2 Building in TA- 15 .

\section{Site: Airport No. 1}

Location: At the Los Alamos Airport.
Excavation by: Frederick C. V. Worman, in April 1951.

The ruin: The site probably had five rooms with walls of large unshaped tuff blocks.

Pottery: Santa Fe Black on White.

Stone artifacts: One flaked axe and a broken mano.

Ground plan: None available.

Site: Airport No. 2

Location: At the Los Alamos Airport.

Excavated by: Frederick C. V. Worman, in A.pril 1951.

The ruin: Nine rooms with walls of large unshaped tuff blocks (Fig. A-45). No other features noted. Many charred corn cobs and kernels were recovered from room 3.

Pottery: Santa Fe Black on White and unspecified glaze paint sherds.

Stone artifacts: None recorded.

Ground plan: Rough drawing in Worman's notebook (Fig. A-46).

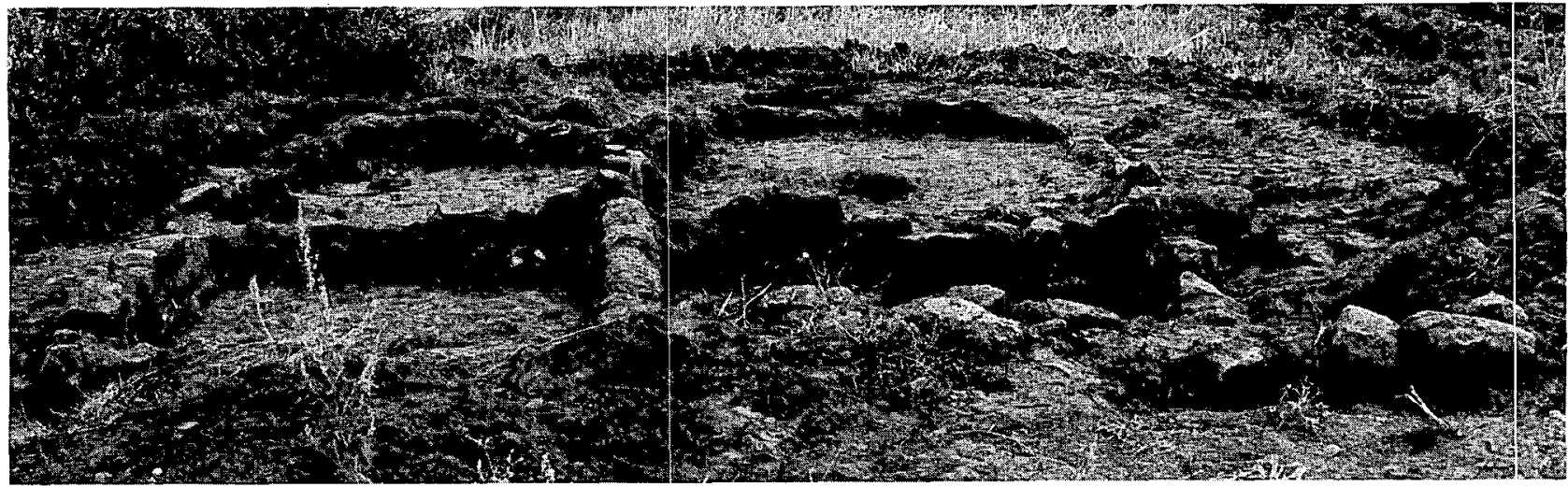

Fig. A-43

$R$ Site No. 2 or LA 4666 from the east. 


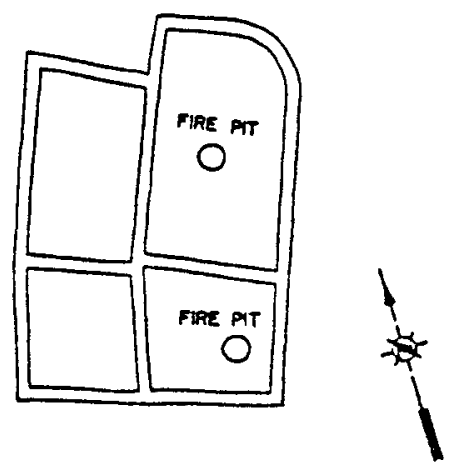

Fig. A-44.

$R$ Site No. 2, LA-4666 as shown on LASL drawing ENG-R-4450.

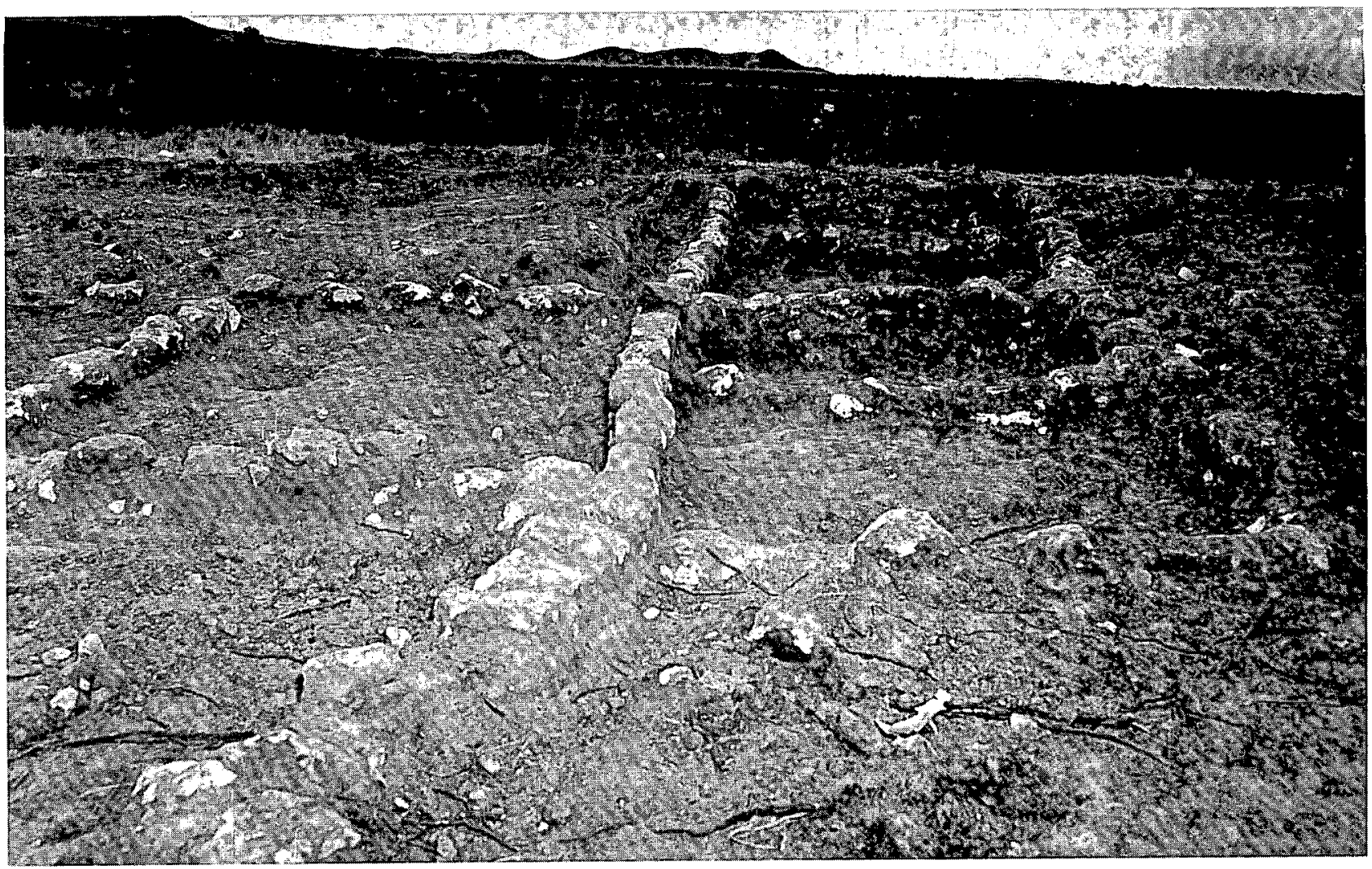

Fig. A-45.

Airport Ruin No. 2. The view is toward the north. 


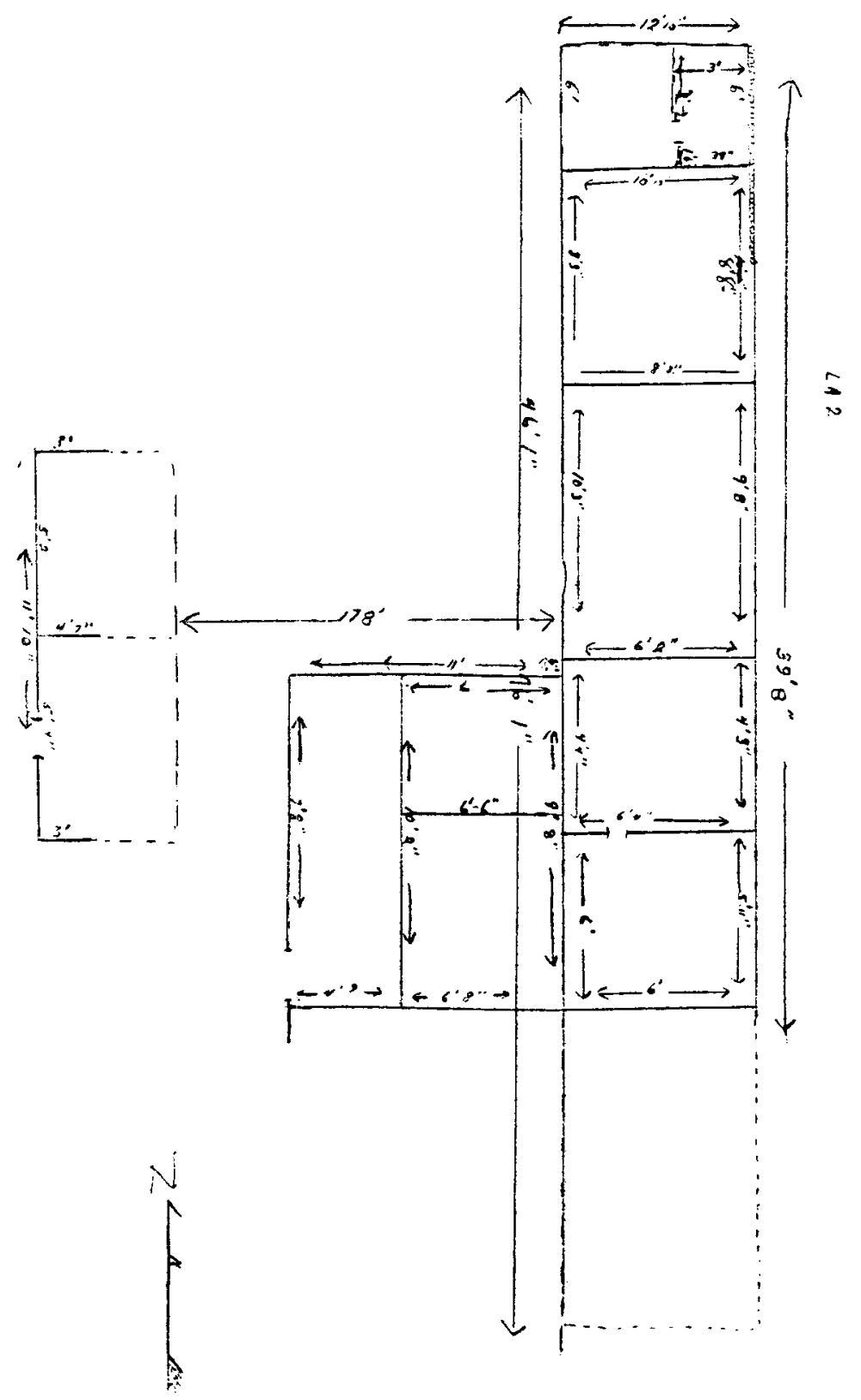

Fig. A-46.

Rough drawing of Airport Ruin No. 2 in Worman's notebook. 


\section{BIBLIOGRAPHY}

"They Found Awanyu's Gifts," The Atom 1 (11), 19 21 (November 1964), Los Alamos Scientific Laboratory, Los Alamos, New Mexico.

Bandelier, Adolph F., "Final Report of Investigations Among the Indians of the Southwestern United States, Carried on Mainly in the Years from 1880 to 1885, Parts I and II," Papers of the Archaeological Institute of America, American Series III and IV, 1890 and 1892, Boston, Massachusetts.

Beyer, Hermann, "Mito y Simbolismo del Mexico Antiguo," El Mexico Antiguo 10 (1965), Mexico.

Breternitz, David A., "An Appraisal of Tree Ring Dated Pottery in the Southwest," in Anthropological Papers of the University of Arizona, No. 10 (University of Arizona Press, Tucson, 1966).

Bryan, Kirk, and J. H. Toulouse, Jr., "San Jose Non-Ceramic Culture and Its Relation to a Puebloan Culture in New Mexico," American Antiquity 8(3), 269-280 (1943), Menasha, Wisconsin.

Caywood, Louis R., Excavations at Rainbow House, Bandelier National Monument (National Park Service, Southwest Archaeological Center, Globe, Arizona, 1966).

Chapman, Kenneth H., "Graphic Art of the Cave Dwellers," El Palacio 3(2) (1916) Santa Fe, New Mexico.

Chapman, Kenneth H., "The Cave Pictographs of the Rito de los Frijoles," El Palacio 4(1), 37-40 (1917), Santa Fe, New Mexico.

Chapman, Kenneth H., "Pajaritan Pictographs, the Cave Pictographs of the Rito de los Frijoles." Reprinted from Edgar Lee Hewett, The Pajarito Plateau and Its Ancient Peoples (University of New Mexico Press, Albuquerque, New Mexico, 1938).

Dick, Herbert W., "Bat Cave," School of American Research, Monograph 27, 1965, Santa Fe, New Mexico.
Douglass, William Boone, "Notes on the Shrines of the Tewa and Other Pueblo Indians of New Mexico," Proceedings of the Nineteenth International Congress of Americanists, Washington, DC, 1917, pp. 344-378.

Ellis, Florence Hawley, "Archaeological History of Nambe Pueblo, 14th Century to the Present," American Antiquity 30(1), 34-42 (1964), Salt Lake City, Utah.

Fretwell, Patricia H., "Preliminary Report of Excavation of Fulton Site 190, Pajarito Plateau." Unpublished manuscript, 1954. Copies at Los Alamos County Historical Museum, Bandelier National Monument, and Museum of New Mexico.

Fretwell, Patricia H., "Final Report, Excavation of Fulton Site 190, Pajarito Plateau." Unpublished manuscript, 1959. Copies deposited at institutions listed above.

Harlow, Francis H., "Recent Finds of Pajaritan Pottery," El Palacio 72(2), 27-33 (1965), Museum of New Mexico, Santa Fe, New Mexico.

Harrington, John Peabody, Ethnogeography of the Tewa Indians, 29th Annual Report, 1907-08, Bureau of American Ethnology, Smithsonian Institution (Government Printing Office, Washington, DC, 1916).

Hawley, Florence M., (see also Florence H. Ellis), "Field Manual of Southwestern Prehistoric Pottery Types," The University of New Mexico Bulletin. Whole Number 291. Anthropological Series 1(4) (University of New Mexico Press, Albuquerque, NM, 1936).

Hendron, Jerome W., Prehistory of El Rito de los Frijoles, Bandelier National Monument (Southwestern Monuments Association, Technical Series No. 1, Coolidge, Arizona, 1940).

Hendron, Jerome W., "We Found America's Oldest Tobacco," New Mexico Magazine 24(11), 11-13, 33, 35, 37 (1946), Santa Fe, New Mexico. 
Hewett, Edgar Lee, "Archaeology of Pajarito Park, New Mexico," American Anthropologist n.s. 6(5), 629-659 (1904).

Hewett, Edgar Lee, "Antiquities of the Jemez Plateau, New Mexico," Bulletin 32, Bureau of American Ethnology, Smithsonian Institution (Government Printing Office, Washington, DC, 1906).

Hewett, Edgar Lee, The Excavations at Puye, New Mexico in 1907. Papers of the School of American Archaeology, No. 4. Archaeological Institute of America, Santa Fe. (Reprint of a 1909 article "Archaeology of the Rio Grande Valley" in Outwest Magazine, Los Angeles, California).

Hewett, Edgar Lee, "The Excavations at El Rito de los Frijoles in 1909," American Anthropologist, n.s. 11(4), 651-673, Lancaster, Pennsylvania.

Hewett, Edgar Lee, "The Excavations at Tyuonyi, New Mexico, in 1908," American Anthropologist, n.s. 11(3), 434-455, Lancaster, Pennsylvania. (Reprinted as paper No. 5 of the School of American Archaeology, Santa Fe, New Mexico).

Hewett, Edgar Lee, "The Pajaritan Culture," American Journal of Archaeology, 2nd Series, XIII(3), 334-344 (1909), Boston, Massachusetts.

Hewett, Edgar Lee, "The Proposed 'National Park of the Cliff Cities'," Papers of the School of American Archaeology, No. 34, Archaeological Institute of America, Santa Fe, New Mexico. Reprinted from El Palacio 3(3), 50-56 (1916).

Hewett, Edgar Lee, Pajarito Plateau and Its Ancient People, 2nd Edition, Revised. (University of New Mexico Press, Albuquerque, New Mexico, 1953).

Irwin-Williams, Cynthia, "Picosa: The Elementary Southwestern Culture," American Antiquity 32(4) (1967), Menasha, Wisconsin.

Kan, Michael, Clement W. Meighan, and Henry B. Nicholson, Sculpture of Ancient West Mexico: Nayarit, Jalisco, Colima (Los Angeles County Museum of Art, Los Angeles, 1970).
Kidder, Alfred Vincent, "Pottery of the Pajarito Plateau and of Some Adjaceni Regions in New Mexico," Memoirs of the American Anthropological Association, No. 2, 411-462 (1915), Lancaster, Pennsylvania.

Krieger, Alex D., Culture Complexes and Chronology in Northern Texas (University of 'Texas Publication Number 4640, Austin, Texas, 1946).

Lange, Charles H., Cochiti, A New Mexico Pueblo, Past and Present (University of Texas Press, Austin, Texas, 1959).

Lange, Charles H., and Carroll L. Riley, Eds.,The Southwestern Journals of Adolph F. Banclelier, 1880-82 (University of New Mexico Press, Albuquerque, New Mexico, 1966).

Lister, Robert H., "Arrows Recovered from Long House Ruin, Bandelier National Monument," Southwestern National Monuments Monthly Report, Supplement for July 1940, pp. 64-66, Coolidge, Arizona.

Lister, Robert H., "Otowi Artifacts," Southwestern National Monuments Monthly Report, Supplement for October 1940, pp. 272-277, Coolidge, Arizona.

Maxon, James Clark, "A Study of Two Prehistoric Pueblo Sites on the Pajarito Plateau, New Mexico," Unpublished Thesis presented to the Faculty of the University of Wisconsin, 1969.

Mera, H. P., "A Survey of the Biscuit Ware Area in Northern New Mexico," Technical Series Bulletin, No. 6 (Archaeological Survey, Laboratory of Anthropology, Inc., Santa Fe, New Mexico, 1934).

Nicholson, Henry B., "Religion in Pre-Hispanic Central Mexico," in "Archaeology of Northern MesoAmerica," Handbook of Middle American Inaians, Part I, Vol. 10, Robert Wauchope, Gen. Ed. (Uriversity of Texas Press, Austin, Texas, 1971).

Purtymun, William D., and William R. Kennedy, "Geology and Hydrology of Mesita del Buey," Los Alamos Scientific Laboratory report LA-4460, Los Alamos, New Mexico (1971). 
Reed, Erik K., "Population Shifts in the PreSpanish Southwest," Texas Archaeological and Palaeontological Society 21, 90-96 (1950), Lubbock, Texas.

Reed, Erik K., "Cultural Areas of the Pre-Spanish Southwest," New Mexico Quarterly XXI(4), 428-439 (1951), University of New Mexico, Albuquerque.

Robinson, William J., John W. Hannah, and Bruce G. Harril, Tree Ring Dates from New Mexico Central Rio Grande Area (Laboratory of Tree Ring Research, University of Arizona, Tucson, 1972).

Smiley, T. L., S. A. Stubbs, and Bryant Bannister, "A Foundation for the Dating of Some Late Archaeological Sites in the Rio Grande Area, New Mexico: Based on Studies in Tree Ring Methods and Pottery Analyses," University of Arizona Bulletin 24(3) (1953) and Laboratory of Tree Ring Research Bulletin No. 6 (1953), Tucson, Arizona.

Snow, David H., "The Excavation of Saltbush Pueblo, Bandelier National Monument, New Mexico," Museum of New Mexico, Laboratory of Anthropology Notes Number 97, Santa Fe, New Mexico, 1974.

Stallings, William S., Jr., "Southwestern Dated Ruins: 1," Tree Ring Bulletin 4(2), 3-5 (1937), Tucson, Arizona.

Stevenson, M. C., "The Zuñi Indians," Bureau of American Ethnology Annual Report 23, Smithsonian Institution, U. S. Government Printing Office, Washington, DC (1904).

Stubbs, Stanley A., and W. S. Stallings, Jr., "The Excavation of Pindi Pueblo, New Mexico," Monographs of the School of American Research and the Laboratory of Anthropology, No. 18, Santa Fe, New Mexico, 1953.

Turney, John F., "Archaeological Survey of the Otowi Section, Bandelier National Monument," Unpublished manuscript. Bandelier National Monument, New Mexico, 1955.
Wendorf, Fred, and Erik K. Reed, "An Alternative Reconstruction of Northern Rio Grande Prehistory," El Palacio 62(5 and 6), 131-173 (1955), Museum of New Mexico, Santa Fe, New Mexico.

Wetherington, Ronald K., "Excavations at Pot Creek Pueblo," Fort Burgwin Research Center, Number 6, Taos, New Mexico, 1968.

Wilson, Mrs. L. L. W., "Excavations at Otowi," El Palacio 3(2), 28-36 (1916), Museum of New Mexico, Santa Fe, New Mexico.

Wilson, Mrs. L. L. W., "Three Years at Otowi," El Palacio 5(18), 290-295 (1918), Museum of New Mexico, Santa Fe, New Mexico.

Worman, Frederick C. V., "1957 Archaeological Salvage Excavations at Los Alamos, New Mexico: A Preliminary Report," El Palacio 66(1), 10-15 (1959), Museum of New Mexico, Santa Fe, New Mexico.

Worman, Frederick C. V., "Archaeological Salvage Excavations on the Mesita del Buey, Los Alamos County, New Mexico," Los Alamos Scientific Laboratory report LA-3636 (1976), Los Alamos, New Mexico.

Worman, Frederick C. V., and Charlie R. Steen, Excavations on Mesita de los Alamos, Los Alamos County, New Mexico (in press).

Young, Dwight S., "Dendrochronology," in Preliminary Report of Excavation of Fulton Site 190, Pajarito Plateau," by Patricia Fretwell, unpublished manuscript 1945, Museum of New Mexico, Santa Fe.

Young, Dwight S., "Yearly Report on LA 170 Cave Site," unpublished manuscript 1957, Museum of New Mexico, Santa Fe. 